FACULDADE DE FILOSOFIA, LETRAS E CIÊNCIAS HUMANAS DEPARTAMENTO DE LETRAS CLÁSSICAS E VERNÁCULAS PROGRAMA DE PÓS-GRADUAÇÃO EM ESTUDOS COMPARADOS DE LITERATURAS DE LÍNGUA PORTUGUESA

\title{
HEIDI STRECKER-GOMES
}

Figura de Marília: aspectos da poética de

Tomás Antônio Gonzaga

Versão corrigida

São Paulo

2020 


\section{HEIDI STRECKER-GOMES}

Figura de Marília: aspectos da poética de Tomás Antônio Gonzaga

Versão corrigida

Dissertação de Mestrado apresentada ao Programa de Pós-Graduação em Estudos Comparados de Literaturas de Língua Portuguesa da Faculdade de Filosofia, Letras e Ciências Humanas da Universidade de São Paulo, como parte dos requisitos para obtenção do título de Mestre em Estudos Comparados de Literaturas de Língua Portuguesa.

Orientador: Prof. Dr. Jean Pierre Chauvin

São Paulo

2020 
Autorizo a reprodução e divulgação total ou parcial deste trabalho, por qualquer meio convencional ou eletrônico, para fins de estudo e pesquisa, desde que citada a fonte.

Catalogação na Publicação

Faculdade de Filosofia, Letras e Ciências Humanas da Universidade de São Paulo

\section{S914f Strecker-Gomes, Heidi}

Figura de Marília: aspectos da poética de Tomás Jean Pierre Chauvin - São Paulo, 2020,

Jean Pierre Chauvin $170 \mathrm{f}$.

Dissertação (Mestrado)- Faculdade de Filosofia Paulo. Departamento de Letras Clássicas Ârea de concentração: Estudos Comparados de

1. Poesia bucólica. 2. Tomás Antônio Gonzaga. 3. Marília de Dirceu. 4. Século XVIII. 5. Poesia orient. II 
UNIVERSIDADE DE SÃO PAULO

FACULDADE DE FILOSOFIA, LETRAS E CIÊNCIAS HUMANAS

\section{ENTREGA DO EXEMPLAR CORRIGIDO DA DISSERTAÇÃO/TESE}

Termo de Ciência e Concordância do (a) orientador (a)

Nome do (a) aluno (a): Heidi Strecker Gomes

Data da defesa: $18 /$ dezembro/2020

Nome do Prof. (a) orientador (a): Jean Pierre Chauvin

Nos termos da legislação vigente, declaro ESTAR CIENTE do conteúdo deste EXEMPLAR

CORRIGIDO elaborado em atenção às sugestões dos membros da comissão Julgadora na sessão de defesa do trabalho, manifestando-me plenamente favorável ao seu encaminhamento e publicação no Portal Digital de Teses da USP.

São Paulo, 15/2/2021.

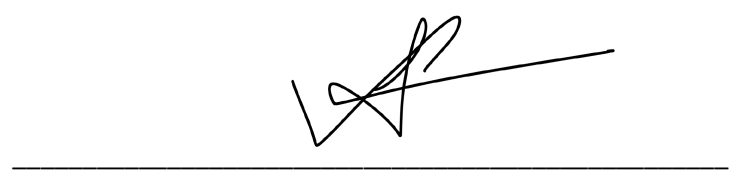

(Assinatura do (a) orientador (a) 
STRECKER-GOMES, H. Figura de Marília: aspectos da poética de Tomás Antônio Gonzaga. Dissertação apresentada à Faculdade de Filosofia, Letras e Ciências Humanas da Universidade de São Paulo como parte dos requisitos para obtenção do título de Mestre em Letras (Estudos Comparados de Literaturas de Língua Portuguesa).

Aprovada em: 18/12/2020

Banca Examinadora

Prof. Dr. Jean Pierre Chauvin (Presidente) Instituição: Universidade de São Paulo Julgamento: Assinatura:

Prof. Dr. João Adolfo Hansen Instituição: Universidade de São Paulo Julgamento: Assinatura:

Prof. Dr. João Angelo Oliva Neto Instituição: Universidade de São Paulo Julgamento: Assinatura:

Prof. Dr. Marcelo Lachat Instituição: Unifesp

Julgamento: Assinatura: 


\section{DEDICATÓRIA}

Aos meus pais Lore Frida Strecker e Nilo Campos Gomes (in memorian).

À memória de Alexandre Eulálio Pimenta da Cunha, primeiro orientador, pelo exemplo de integridade intelectual, gentileza e generosidade. 


\section{AGRADECIMENTOS}

A Jean Pierre Chauvin, pela orientação segura, dedicada e afetuosa.

A João Adolfo Hansen e João Angelo Oliva Neto, pela generosidade e argutos comentários em meu exame de qualificação e defesa. A Marcelo Lachat e Rodrigo Gomes de Oliveira Pinto, pelas instigantes e decisivas observações em minha defesa da dissertação.

A Adma Fadul Muhana, Lineide do Lago Salvador Mosca, Maria do Socorro Fernandes de Carvalho, Paulo Fernando Motta e Rejane Vecchia, pelas lições preciosas durante a elaboração deste trabalho.

Aos colegas Caio Esteves de Souza, Gustavo Luiz Nunes Borghi e Leonardo Zuccaro, pela acolhida no campo dos estudos retórico-poéticos e pelo estímulo e presença constante em minha formação.

Ao meu querido amigo Roberto Amado, uma espécie de duplo em minha trajetória acadêmica, pela carinho e pela troca.

Ao amigo Hélio de Seixas Guimarães, pelo interesse em Marília, pelas conversas e pela ajuda desde sempre.

A Fabiana Carelli, Emerson Inácio, Mário César Lugarinho e Maurício Salles Vasconcelos, pela acolhida na CCP como representante discente. A Tania Celestino de Macedo e Antônio Vicente Seraphimi Pietroforte, pelo convívio produtivo durante os Encontros de Literatura Comparada.

A Vera, Julio, Lucas, Marinês, Giovanna e demais funcionários da Secretaria do DLCV e do CELP, pelo auxílio inestimável nos trâmites acadêmicos e burocráticos que tornaram possível esta pesquisa.

A minha irmã Márion, a meus irmãos Marcos e Érico e a meus cunhados Mário César Carvalho, Miria Benincasa Gomes e Verônica Papoula Mendes, pelo estímulo à realização deste trabalho.

Aos amigos parceiros de trabalho Sergio Rossoni, Elizangela Dias e Neila Brasil, pela delicadeza e pelo convívio estimulante.

A Kelly Cristina da Silva, pelo auxílio indispensável e sempre bem-humorado.

À Capes, que me auxiliou com uma bolsa de mestrado, de julho de 2019 a dezembro de 2020. 


\section{RESUMO}

STRECKER-GOMES, H. Figura de Marília: aspectos da poética de Tomás Antônio Gonzaga. São Paulo, 2020. 159 p. Dissertação (Mestrado) - Faculdade de Filosofia, Letras e Ciências Humanas, Universidade de São Paulo, 2020.

O objetivo desta pesquisa é estudar a figura de Marília, central na obra Marília de Dirceu do poeta luso-brasileiro Tomás Antônio Gonzaga (1744-1810). A partir de uma perspectiva histórica, buscamos evidenciar aspectos da poética do autor conforme as convenções retórico-poéticas de seu tempo. Analisamos tópicos formais e características discursivas desse poema em duas partes, a primeira editada em 1792 e a segunda, em 1799. Para tal, reexaminamos a longa tradição crítica brasileira que interpretou o idílio ficcionalizado no poema ou como expressão de uma subjetividade empírica ou como reflexo de determinada realidade social. Também desvinculamos a figura de Marília da personagem histórica Maria Doroteia Joaquina de Seixas, que a teria inspirado. Nesse sentido, o "casal de sonhos" Dirceu e Marília afasta-se da esfera biográfica e empírica, do mesmo modo que o discurso de Tomás Antônio Gonzaga é compreendido além da esfera documental e biográfica, deslocando-se para o terreno das convenções poéticas da segunda metade do século XVIII. Compreendida como poesia regrada retoricamente, ressaltamos aspectos da poética de Tomás Antônio Gonzaga que estruturam seu poema. Tendo esse ponto de partida, apontamos a centralidade da figura de Marília de Dirceu na obra lírica atribuída a Gonzaga, descrevendo algumas de suas "facetas": um nome da tradição bucólica, a interlocutora privilegiada da persona poética, a pastora que compõe o par com Dirceu, uma personagem da ficção mitológica, um retrato feminino pintado pelo poeta, e, por fim, como uma espécie de intermédio conciliatório entre a primeira e a segunda parte do poema.

PALAVRAS-CHAVE: Tomás Antônio Gonzaga; Marília de Dirceu; poesia lusobrasileira; bucolismo; século XVIII. 


\begin{abstract}
STRECKER-GOMES, H. Figure of Marília: aspects of Tomás Antônio Gonzaga poetics. São Paulo, 2020. 159 p. Dissertation (master degree) - Faculdade de Filosofia, Letras e Ciências Humanas, Universidade de São Paulo.
\end{abstract}

The purpose of this research is to study the figure of Marilia, central to the work Marilia de Dirceu by the Luso-Brazilian poet Tomás Antônio Gonzaga (1744-1810). From a historical perspective, we seek to highlight aspects of the author's poetics according to the rhetorical conventions of his time. We analyze formal topics and discursive characteristics of this extensive poem in two parts, the first edited in 1792 and the second in 1799. To this end, we examined the long Brazilian critical tradition that interpreted the fictionalized idyll in the poem or as an expression of an empirical subjectivity or as a reflection of a certain historical reality. We also dissociated Marília from the historical character Maria Doroteia Joaquina de Seixas, who would have inspired her. In this sense, the poetic couple Dirceu and Marilia moves away from the biographical and empirical sphere, in the same way that Tomás Antonio Gonzaga's discourse is understood beyond the documentary and biographical sphere, moving into the terrain of the poetic conventions of the second half of the 18th century. Understood as rhetorically ruled poetry, we highlight aspects of Tomás Antonio Gonzaga's poetics that structure his poem. Having this starting point, we point out the centrality of the figure of Marília de Dirceu in the lyrical work attributed to Gonzaga, describing some of her "facets": a name from the bucolic tradition, the privileged interlocutor of the poetic persona, the shepherdess who composes the poetic partnership with Dirceu, a character from mythological fiction, a female portrait painted by the poet, and, finally, as a kind of conciliatory intermediate between the first and second part of the poem.

KEY WORDS: Tomás Antônio Gonzaga; Marília de Dirceu; Luso-Brazilian poetry; pastoral; 18th century. 


\section{Lista de quadros}

Quadro 1 - Cotejo de numeração das liras nas diferentes edições - Parte I.............. p. 34

Quadro 2 - Cotejo de numeração das liras nas diferentes edições - Parte I1 ............. p. 35

Quadro 3 - Relação entre extensão dos períodos gramaticas e quantidade de versos

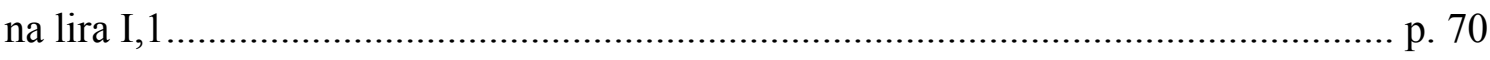

Quadro 4 - Esquema de versos, métrica e rima na estrofe gonzaguiana - Parte I....... p. 73

Quadro 5 - Esquema de versos, métrica e rimas na estrofe gonzaguiana - Parte II.... p. 74

Quadro 6 - Extensão das estrofes e quantificação de seu emprego............................. p. 75

Quadro 7 - O lugar de Marília na parte I de Marília de Dirceu ................................. p. 130

Quadro 8 - O lugar de Marília na Parte II de Marília de Dirceu................................ p. 131

Quadro 9 - Quadro resumo da presença de Marília de Dirceu .................................... p. 133 


\section{Lista de figuras}

Figura 1 - Imagem da capa da edição princeps de Marília de Dirceu - Edição fac-similada (1792). In: GONZAGA, Tomás Antônio. Marília de Dirceu / por T.A.G. - Rio de Janeiro: Fundação Biblioteca Nacional, Dep. Nacional do Livro, 1995. p. 3. Fac-símile de: Lisboa: na Typografia Nunesiana, 1792. p. 173

Figura 2 - Imagem do poeta Tomás Antônio Gonzaga a partir do retrato a óleo de Maximiano Mafra (Tomás Gonzaga no cárcere), exposto no salão de 1844 no Rio de Janeiro. Reproduzida em: Marília de Dirceu (Seleção das liras autênticas). (Ed. lit.) Alberto Faria. Rio de Janeiro: Anuário do Brasil, 1922 ............................................. p. 174

Figura 3 - Imagem da página inicial da edição princeps de Marília de Dirceu. - Edição fac-similada (1792). In: GONZAGA, Tomás Antônio. Marília de Dirceu / por T.A.G. Rio de Janeiro: Fundação Biblioteca Nacional, Dep. Nacional do Livro, 1995. p. 5. Facsímile de: Lisboa: na Typografia Nunesiana, 1792 p. 175 


\section{SUMÁRIO}

Introdução

p. 25

1. Capítulo 1 - Estado da questão................................................................. p. 27

1.1. Persistência de Marília............................................................................................... p. 29

1.2. Um público presente............................................................................... p. 41

1.3. Maria Joaquina Doroteia de Seixas................................................................ p. 42

1.4. Um tortuoso caminho crítico..................................................................... p. 46

1.5. Uma abordagem retórico-poética de Marília de Dirceu..................................... p. 50

2. Capítulo 2 - Uma lira exemplar ……......................................................... p. 53

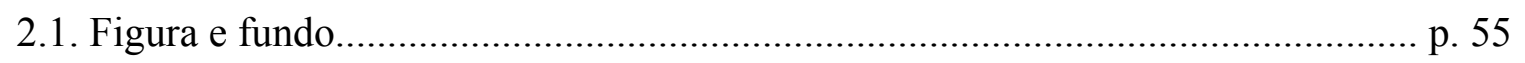

2.2. Aspectos da poética de Tomás Antônio Gonzaga................................................. p. 61

3. Capítulo 3 - A força de Marília bela …............................................................ p. 103

3.1. O nome de Marília......................................................................................... p. 107

3.2. O privilégio da interlocução........................................................................... p. 119

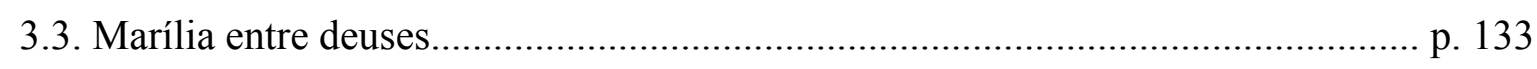

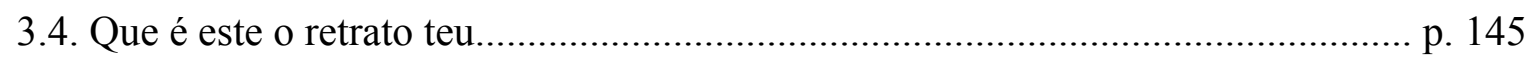

3.5. Então mais vivamente te diviso................................................................... p. 152

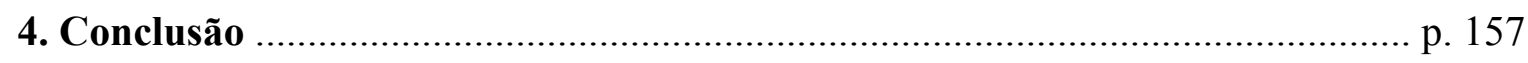

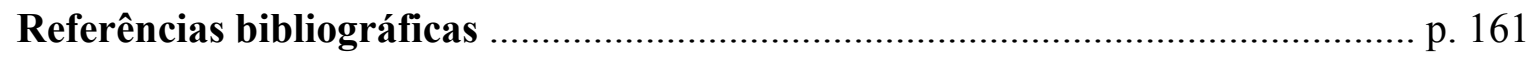




\section{NOTA}

Posso dizer que preparei esta dissertação duas vezes. Na primeira vez cursei o mestrado em Teoria Literária na Unicamp e tive como orientador Alexandre Eulálio Pimenta da Cunha, um intelectual afeito a meu objeto de estudo. Meu projeto já era então estudar a figura de Marília na obra lírica de Tomás Antônio Gonzaga. Com o falecimento de Alexandre, tive como orientador o professor Roberto Schwarz. Naquele período, na década de 1980, os estudos retóricos e poéticos ainda não estavam ao alcance do estudante; um poeta do século XVIII era entendido pela crítica apenas como um precursor do Romantismo e importante elo para a formação da literatura nacional, embora ainda estivesse preso às convenções arcádicas. Um pedido de bolsa à Fapesp foi denegado sob o argumento de que a pesquisa que eu desejava realizar era de "amplas proporções, e oscilava entre aspectos históricos e internos da obra", o que seria impossível numa dissertação de mestrado. Alexandre justificou que a pesquisa "muito poderia se enriquecer, com essa alternância abrangente". Contudo não consegui o auxílio. Após estudar a historiografia do poema de Gonzaga e analisar estruturalmente as liras de Marília de Dirceu, meus pressupostos teóricos se esgotaram, oriundos da tradição crítica brasileira romântico-modernista. Não apenas isso. O falecimento de meu orientador e depois, em curto espaço de tempo, o de meu pai também, assim como o começo de minha vida profissional interromperam meus estudos de pós-graduação. Optei por concluir a graduação em Filosofia, que já estava em curso, e recolhi todo meu material numa grande caixa-arquivo.

Nunca esqueci Marília, no entanto; após um longo período fora da universidade, retomei meus estudos, primeiro como aluna de extensão cultural, em seguida como ouvinte em disciplinas da pós-graduação e finalmente como aluna especial do programa de pósgraduação em Estudos Comparados de Literaturas de Língua Portuguesa no DLCV. Tive a oportunidade de cursar a disciplina de João Adolfo Hansen, Práticas de Representação Luso-Brasileiras dos Séculos XVI, XVII e XVIII. Ao analisar os condicionantes institucionais e os códigos linguísticos dessa produção e explanar sobre diversos textos doutrinários da longa tradição retórica e poética que permite compreendê-los como práticas discursivas, as aulas do professor Hansen abriram perspectivas novas para o estudo da 
poesia de Tomás Antônio Gonzaga. Também pude entrar em contato com uma ampla bibliografia que incluía textos de historiadores, tratadistas, literatos e críticos, que ampliou largamente meu horizonte teórico. Uma série de conceitos operatórios, que até então eram desconhecidos para mim, foram introduzidos pelo professor para tratar de textos “coloniais" luso-brasileiros como auctoritas, engenho, emulação, imitação, éthos e decoro.

As aulas da disciplina Cultura Luso-brasileira nos séculos XVIII e XIX, ministradas por Jean Pierre Chauvin, me aproximaram ainda mais do tema de minha pesquisa. Consultei o professor Chauvin sobre a possibilidade de me orientar e ele prontamente aquiesceu, acrescentando que tinha interesse e gosto pela obra de Tomás Antônio Gonzaga. Abri meu baú gonzaguiano. Recomecei as pesquisas e entrei em contato com um quadro teórico totalmente renovado. O volume Marília de Dirceu de Tomás Antonio Gonzaga ou a poesia como imitação e pintura, de Fernando Cristóvão, publicado em Portugal, representou um grande alento para o estudo da figura de Marília de Dirceu. No Brasil, as pesquisas pioneiras de Ivan Teixeira, Antônio Medina, Alcir Pécora, Marcello Moreira, Adma Muhana e João Adolfo Hansen abriram um campo novo e amplo para os estudos de obras do séculos XVI a XVIII nas ditas letras coloniais luso-brasileiras. Retomei a pesquisa sobre Marília de Dirceu, de Tomás Antônio Gonzaga, e encontrei autores que tinham moldado uma nova visão sobre a poética do autor e seu período histórico. A dissertação que apresento agora é tributária - felizmente - do tempo transcorrido entre a primeira e a segunda versões deste trabalho. Tenho a meu favor a fidelidade ao tema de Marília. No entanto, mesmo com o tempo dilatado entre a primeira versão e o trabalho que ora apresento, recorro à benevolência do leitor para os limites e imprecisões deste estudo. 


\section{INTRODUÇÃO}

Este trabalho tem por objetivo estudar a figura de Marília na obra lírica Marília de Dirceu, atribuída ao poeta luso-brasileiro Tomás Antônio Gonzaga (1744-1810). Partindo da hipótese de que ela é a força aglutinadora do poema, que consiste de duas partes, publicadas em datas diferentes com o mesmo título, buscamos examinar como o discurso do poeta modula a sua presença ou, dizendo de outro modo, como Marília se apresenta sob múltiplas "facetas".

No primeiro capítulo, efetuamos um estudo da trajetória crítica da obra, que se consolidou no século XIX e se prolongou além da segunda metade do século XX, com seus pressupostos biográficos, nacionalistas e psicológicos, abordando a obra como documento histórico e expressão de sentimentos e emoções de seu autor. Ainda neste capítulo, buscamos justificar a metodologia adotada, que entende o poema como um artefato retórico, tributário das convenções poéticas e de gênero e do princípio da imitação Nesse sentido, o poema de Gonzaga dialoga com a longa tradição da poesia bucólica e com as demais formas poéticas vigentes na Europa do século XII ao XVIII.

No segundo capítulo, examinamos aspectos importantes da poética de Tomás Antônio Gonzaga a partir da análise da lira I,1, que se pode considerar programático, ao instituir os procedimentos retóricos do discurso do poeta em termos da invenção, da elocução e da disposição. O estudo dessa lira permitiu investigar elementos recorrentes do livro como um todo. Procuramos examinar elementos como a estrutura estrófica, a extensão das liras, o metro, esquema rítmico, a escolha do léxico e a presença de lugarescomuns que normatizam essa poesia e o papel da tópica pertinente ao gênero pastoral.

$\mathrm{Na}$ terceira parte, por fim, buscamos examinar as diversas figuras de Marília conforme determinadas pela poética de Gonzaga. Em primeiro lugar, procuramos contextualizar o nome da pastora em diversos poetas greco-latinos, quinhentistas, seiscentistas e setecentistas, fazendo um estudo do nome que serviu à tradição do gênero pastoral. A seguir, traçamos uma espécie de mapa da configuração de Marília na totalidade do poema, demonstrando como as liras estão todas interligadas pela presença da pastora. Em grande parte dos poemas, a persona poética dirige-se a ela explicitamente, atribuindolhe o papel de interlocutora. Também serão examinadas outras representações da figura de Marília: a personagem mitológica, a imagem de retrato e por fim uma espécie de intermédio conciliatório a unir das duas partes de Marília de Dirceu. Investigando 
procedimentos poéticos, linguísticos e retóricos de que o poeta se vale, buscamos compreender como essas diferentes facetas se articulam. Finalmente, procuramos demonstrar como a presença de Marília unifica e dá coesão à obra, servindo como guia para o poeta refazer seus temas e inserir a cena bucólica dentro do novo cenário da masmorra. ${ }^{1}$

\footnotetext{
"O termo figura será utilizado nesse trabalho em seu sentido corrente, significando "aspecto", "feitio", "figuração", "forma", "imagem", "faceta". Os dicionários contemporâneos registram, entre outras, as seguintes acepções para o termo figura: "forma exterior, o contorno externo de um corpo"; "configuração"; "qualquer representação visual (esculpida, pintada, gravada etc.) de uma forma inspirada na realidade ou na imaginação"; "imagem que ger. acompanha um texto; (mais us. no pl.) "ilustração, estampa, impressão visual"; "imagem, figuração" fig. "imagem sem nitidez, forma apenas vislumbrada, entrevista"; "vulto"; "representação simbólica de algo"; "imagem que remete a alguma coisa"; "símbolo, emblema, alegoria"; fig "uma ideia, descrição etc. em destaque, em foco"; fig "personagem ou personalidade de importância". Os dicionários registram ainda acepções ligadas à Retórica ("todo recurso linguístico que, desviado de uma norma linguística, cria efeitos de expressividade que revestem uma parte de um enunciado de realce, contraste, sentimento") e à Lógica ("cada uma das quatro formas possíveis de silogismo"). A sinonímia de figura envolve os termos aspecto, aparência, apresentação, ar, compleição, configuração, conformação, corpo, feitio, figuração, forma, presença, talhe. (In: Grande Dicionário Houaiss. Dicionário Houaiss de Lingua Portuguesa. Por Antônio Houaiss. Versão eletrônica.) O Dicionário Bluteau, editado em 1789, registra acepções do termo figura bastante semelhantes aos dicionários contemporâneos. Vejamos: "FIGURA, s. f. a fórma externa, a feição de qualquer coisa v. g. , hum vulto com figura humana. § Modo de fallar diverso do usual, e regularmente sufficiente para declarar os conceitos, feito por motive de brevidade, por energia, ou qualquer belleza, e adorno do discurso. § Pintura. § Symbolo, imagem significativa de coisa futura v. g. , o maná era figura do pão celestial, que Christo nos deixou na Eucharistia. § Figuras, actores, e actrizes. § Em figura, i. e. em acção, ou postura v. g. , pintão a Hercules em figura de receber sobre os hombros o mundo. § Estar em boa, ou má figura, i. e. bom ou mao estado, e circunstancias. (In: Diccionario da lingua portugueza composto pelo padre D. Rafael Bluteau, reformado, e accrescentado por Antonio de Moraes Silva natural do Rio de Janeiro. (Volume 1: A - K) Lisboa: Na Officina de Simão Thaddeo Ferreira, 1789. P. 614/615.) Marcelo Lachat observa como o uso técnico do termo figura implica concepções retóricas e teológicas bastante complexas, constituídas entre os antigos e no período medieval, que não serão tratados neste trabalho. (Em comunicação oral, 18/12/2020.) A genealogia ou arqueologia do conceito de figura foi bem explicitada por autores como Erich Auerbach e João Adolfo Hansen. "Originalmente, figura [...] significava 'forma plástica' ". Sua mais remota ocorrência está em Terêncio. [...] essa formação peculiar (da palavra latina derivada diretamente da raiz, e não do supino) expressa algo vivo e dinâmico, incompleto e lúdico, pois sem dúvida a palavra possui um som gracioso que fascinou muitos poetas.” (Auerbach, 1997, p. 13-14) O sentido de figura como conceito ligado à Retórica foi consolidados por Quintiliano. "Q. distingue os tropos das figuras; o tropo é um conceito mais restrito, referindo-se ao uso de palavras e frases num sentido que não é literal; a figura, por outro lado, é uma forma de discurso que se desvia do seu uso normal e mais óbvio." (Auerbach, 1997, p. 24.) Na teologia cristã, o termo figura pode ser compreendido como "acontecimento profético", como uma "prefiguração". V. AUERBACH, E. Figura. Trad. Duda Machado. Rev. da trad. José Marcos Macedo e Samuel Titan Jr. Pref. Modesto Carone. São Paulo: Ática, 1997 e HANSEN, João Adolfo. Alegoria: construção e interpretação da metáfora. São Paulo: Atual, 1986.

O termo figura, no sentido lato, utilizado neste estudo, poderia ser substituído por "retrato" ou "representação." Neste sentido, a expressão figura de Marília poderia ser entendida como representação de Marília ou imagem de Marília, ganhando assim em precisão. Evidentemente esse sentido relacionado à visualidade é fundamental, mas se perdem as outras figurações de Marília que serão estudadas nessa dissertação, como interlocutora, como um nome, como uma personagem e como intermédio conciliatório. Optamos, portanto, por manter o sentido corrente, poético e abrangente de figura.
} 
1. CAPÍTULO 1 - ESTADO DA QUESTÃo 


\subsection{Persistência de Marília}

A obra lírica de Tomás Antônio Gonzaga, bem como a figura de Marília de Dirceu - central em sua poética -, conquistaram espaço importante na historiografia literária brasileira. As liras atribuídas a Tomás Antônio Gonzaga foram publicadas em 1792 (Primeira Parte, pela Typografia Nunesiana, no Porto, assinada por T.A.G. ${ }^{2}$ ) e em 1799 (Primeira e Segunda Partes reunidas pela Oficina Nunesiana, em Lisboa, assinadas por T.A.G.). ${ }^{3}$ As duas partes, juntas, constituem a obra que hoje se conhece como Marília de Dirceu. Nas primeiras edições, observamos a seguinte disposição das liras:

$$
\begin{aligned}
& 1^{\mathrm{a}} \text { parte }=33 \text { liras (edição princeps, 1792) } \\
& 2^{\mathrm{a}} \text { parte }=32 \text { liras (edição princeps, 1799) }
\end{aligned}
$$

Chama atenção a simetria existente entre a primeira e a segunda partes da obra, com quase a mesma quantidade de liras, numeradas sequencialmente. As duas partes do poema sugerem harmonia e equilíbrio e são vazadas na mesma poética, centrada na figura de Marília. Marília de Dirceu compreende, portanto, dois volumes, editados em diferentes datas, com um intervalo de sete anos.

A edição dos livros é questão controversa, pois não se sabe quem seria responsável por mandar os manuscritos a Portugal, quem teria organizado os poemas para publicação ou feito as tratativas com seus editores. ${ }^{4}$ Teria sido o próprio Tomás Antônio

\footnotetext{
${ }^{2}$ Houve duas impressões dessa edição. Na primeira, a página 20 foi numerada erroneamente como página 02. Na segunda tiragem, o erro está corrigido. Cf. Moraes, 1969, p. 162-163.

${ }^{3}$ Rodrigo Gomes de Oliveira Pinto chama a atenção para a recorrência da publicação da obra sob as iniciais T.A.G., sobre a qual é possível considerar algumas hipóteses: "Essas iniciais, em substituição ao nome Tomás Antônio Gonzaga, operam como forma de manter o autor humildemente oculto? Ou, noutra chave de leitura, seria o degredo a razão política possível para explicá-las? O que convencionou o uso das iniciais nas práticas editoriais setecentista?” (Manuscrito, 13/12/2020) João Angelo Oliva Neto também questiona essa ocorrência (Comunicação oral, 18/12/2020). É muito possível que a publicação, mal escondendo o nome do autor sob suas iniciais, tenha relação com a condição política do poeta/magistrado, uma vez que a primeira edição, em 1792, coincidiu com a partida de Tomás Antônio Gonzaga, sentenciado por crime de lesamajestade, para o degredo em Moçambique,. Observa-se em publicações de poetas luso-brasileiros do período essa prática não é corrente, podendo-se citar como exemplo as publicações de Cláudio Manuel da Costa, Silva Alvarenga, Basílio da Gama, Santa Rita Durão e outros, que trazem na capa o nome do autor. V. MORAES, 1969.

${ }^{4}$ Joaci Furtado pondera também que "a obra foi publicada pela primeira vez em 1792, em Lisboa, com seu autor já no degredo em Moçambique pela participação na conspiração contra o domínio colonial português em Minas Gerais - o que indica que sua condição de réu, desde 1789, não obliterou o contato, direto ou indireto, com seu editor em Portugal, ou não impediu que alguém encaminhasse os originais para publicação". In FURTADO, Joaci Pereira, A sorte deste mundo: percursos de Marília de Dirceu no século XIX. Literatura: teoria e prática, v. 36, n. 72., 2018, p. 75.
} 
Gonzaga? Não há consenso entre os especialistas. Uma hipótese levantada pelo bibliófilo Rubem Borba de Moraes sugere que os manuscritos teriam sido levados a Portugal pelo primo do poeta, Tomé Joaquim Gonzaga. ${ }^{5}$ Por sua vez, o biógrafo Adelto Gonçalves afirma que Gonzaga, antes de partir para o exílio, teria pedido ao intendente Pires Bandeira que levasse para Lisboa a segunda parte de Marília de Dirceu. Bandeira estava no Rio de Janeiro prestes a embarcar para Portugal, em 1789, nomeado desembargador da Relação do Porto. ${ }^{6}$

A atribuição da autoria de Marília de Dirceu foi um processo longo, pois novas edições acrescentavam novas liras ou rearranjavam a ordem da composição. Simultaneamente, surgiram edições falsas e anônimas da obra. Em 1800, foi publicada versão apócrifa de uma pretensa terceira parte, pelo editor Bulhões, Lisboa (por T.A.G.), escrita para aproveitar o sucesso de Gonzaga, contendo quinze liras e dois sonetos. $\mathrm{O}$ prólogo desta obra comenta a necessidade de uma nova edição, tendo em vista a pronta extração de quase dois mil exemplares da primeira e segunda partes das liras, em menos de seis meses.

Em 1802, a Oficina Nunesiana, em Lisboa, publicou novamente a obra em duas partes, obedecendo à ordem das edições princeps; porém, acrescentou cinco novas liras à segunda parte, que completa assim 37 liras. Em 1810, foi publicada a primeira edição brasileira, pela Imprensa Régia, no Rio de Janeiro, em três volumes, também com as iniciais T.A.G. Considerada por alguns especialistas a primeira obra impressa no Brasil, ${ }^{7}$ esta edição de Marília de Dirceu incluía as duas primeiras partes, conforme as edições princeps, e a terceira parte falsa publicada por Bulhões.

Em 1811, saiu a edição da Typografia Lacerdina, editada em Lisboa e também assinada por T.A.G., considerada basilar pelo estudioso Rodrigues Lapa, e que serviu de modelo para as numerosas edições subsequentes. A primeira parte contém 37 liras (as quatro a mais seriam depois consideradas pertencentes a uma terceira parte verdadeira); a segunda seção, 38 (isto é, acrescentou-se mais uma lira) e ainda um soneto. Esta edição

\footnotetext{
5 "Não me parece de todo foram de propósito aventar a hipótese desse primo de Tomás Antônio Gonzaga [o poeta Tomé Joaquim Gonzaga] ser a pessoa que entregou ao livreiro Nunes os originais das duas primeiras partes de Marília de Dirceu. Nem tão pouco o palpite que tenho de ser êle o verdadeiro autor da Terceira Parte publicada em 1800 por Bulhões.” In MORAES, 1969, p. 180.

${ }^{6}$ GONÇALVES, A. Gonzaga, um poeta do Iluminismo. Rio de Janeiro, Nova Fronteira, 1999, p. 278.

${ }^{7}$ As máquinas da oficina, que se tornaria a Imprensa Régia, foram trazidas ao Rio de Janeiro pelo príncipe regente, depois D. João VI, em 1808. Em 1810, saem as edições de Marília de Dirceu, de Gonzaga e Ensaios sobre a Crítica, de Pope; em 1811, é publicado Uraguai, de Basílio da Gama, e em 1818, Obras, de Virgílio, e Obras poéticas, de Correa Garção. Cf. ARAÚJO, J. S. Livros e leituras no Brasil antes e depois de João VI. UEFS, Revista Labirintos, n. 8, 2010.
} 
indica que a terceira parte publicada anteriormente era apócrifa ("escrita por pessoa de nosso conhecimento").

No ano seguinte, a Impressão Régia publicou uma terceira parte, esta considerada verdadeira. ${ }^{8}$ Como teriam os editores conseguido os originais? Para Rodrigues Lapa, é possível que "o espólio judicial, entregue em sacos cosidos e lacrados ao desembargador Araújo Saldanha, em 1789, no ato do sequestro, fosse aproveitado nesta edição, como pertença do Estado". ${ }^{9}$ Apenas em 1845 a edição de Marília de Dirceu, pela Laemmert, trouxe por extenso o nome do autor. É a primeira vez em que há um editor literário explícito, J. M. Pereira da Silva, que preparou uma introdução de cunho histórico e biográfico.

Em 1862, veio a público pela Livraria Garnier a edição de Joaquim Norberto, em dois volumes. "Apesar dos equívocos e confusões, a edição mais importante realizada no século XIX por um editor explícito”, segundo Alexandre Eulálio. ${ }^{10}$ Esta versão orientou as edições posteriores até a publicação da edição de Rodrigues Lapa, em 1937, pela editora Sá da Costa. Em 1910, o crítico José Veríssimo publicou a sua edição, também baseada em Joaquim Norberto, porém mais bem cuidada do ponto de vista textual.

Na década de 1930 a bibliografia de Tomás Antônio Gonzaga mereceu ampla revisão, com a publicação dos trabalhos de Oswaldo Mello Braga de Oliveira, ${ }^{11}$ Simões dos Reis ${ }^{12}$ e outros estudiosos, tendo sido decisiva a contribuição de Emmanuel Gaudie Ley, que produziu um catálogo para a Biblioteca Nacional, com as edições da biblioteca em mãos. Ley restabeleceu os fatos, eliminou as edições imaginárias e produziu a primeira bibliografia confiável de Marília de Dirceu, o que abriu caminho para que se estabelecesse a edição crítica da obra.

Em 1937, Rodrigues Lapa publicou, pela Sá da Costa, em Lisboa, Marília de Dirceu e mais poesias. O livro trazia as composições da primeira e da segunda partes, conforme as edições princeps, com os cinco poemas adicionais na segunda parte, extraídos

\footnotetext{
${ }^{8}$ Segundo Moraes, "esta primeira edição da 'verdadeira' Terceira Parte de Marília de Dirceu contém oito liras, dezesseis sonetos e duas odes. As liras 1, 3, 7 e 8 já tinham sido publicadas na primeira parte da edição Lacerdina em 1811. O soneto: 'Obrei quanto o discurso me guiava' também já tinha sido impresso nessa edição. As demais poesias aparecem aqui pela primeira vez.” In MORAES, op. cit. p. 168.

${ }^{9}$ LAPA, Rodrigues. Introdução. GONZAGA, Tomás Antônio. Marília de Dirceu e mais poesias. Pref. e notas de M. Rodrigues Lapa. 2. ed. Lisboa: Sá da Costa, 1944, In p. XXXIV-XXXV. GONZAGA.

${ }^{10}$ EULÁLIO, Alexandre. Obra. In: GONZAGA, Tomás Antônio. Os melhores poemas de Tomás Antônio Gonzaga. São Paulo: Global, 1983.

${ }^{11}$ OLIVEIRA, Oswaldo Mello Braga de. As edições de "Marilia de Dirceu" - Bibliographia completa. Rio de Janeiro: Benedicto de Souza, 1930. 58 p.

${ }^{12}$ SIMÕES DOS REIS, Antonio. Notas Bibliograpbieas. 1. Gonzagucana . A Escragnolle. Doria). Jornal do Commercio do Rio de Janeiro. 21 e 28 de outubro de 1934.
} 
da edição Lacerdina. Incluía, ainda, uma terceira parte, composta por 28 poemas, reproduzindo a edição de 1812 da Impressão Régia, mais um inédito. ${ }^{13}$

Em 1957, o mesmo Rodrigues Lapa publicou a edição crítica das Obras completas de Tomás Antônio Gonzaga I e II - Poesias - Cartas Chilenas - Tratado de Direito Natural. ${ }^{14}$ A obra compreende, além de todos os versos que se podiam atribuir ao poeta e que integram sua obra lírica, as Cartas chilenas, o Tratado sobre o Direito Natural, cartas enviadas de seu exílio moçambicano, minutas autografadas por Gonzaga, além de documentos como trechos do Auto da devassa. Observe-se que esses documentos informam também sobre a trajetória do poeta e sua condição de homem letrado na América portuguesa, contém ainda um estudo biográfico e inúmeras notas. Rodrigues Lapa publicou as liras que compõem Marília de Dirceu em suposta ordem cronológica, juntamente com outros poemas e renumerou-as sequencialmente de 1 a 94. Esse rearranjo desfez a ordem tradicional das liras, presente nas edições anteriores - como se tirasse as estrelas de lugar e as enfileirasse por ordem de tamanho.

Por ocasião do bicentenário de Marília de Dirceu, em 1972, a pesquisadora Melânia Silva de Aguiar publicou uma versão com ilustrações de Guignard de Marília de Dirceu e refez o arranjo tradicional das liras. A mesma disposição das liras figurou no luxuoso volume lançado pela editora Nova Aguilar, A poesia dos inconfidentes, organizado por Domício Proença Filho. Aguiar foi também responsável pela fixação do texto, que eliminou da terceira parte dois sonetos que seriam de Cláudio Manuel da Costa, "Sombras ilustres dos varões formosos" e "As moles asas a bater começa". Esta edição da Nova Aguilar, revista por Melânia Silva de Aguiar, restaurou parcialmente a ordem original das liras para a Primeira e Segunda Partes. A Terceira Parte, nesta edição, compreende oito liras, quatro sonetos, uma ode e ainda dois poemas apresentados apenas pelos títulos, totalizando 25 poemas. As obras completas de Gonzaga compreendem, além de Marília de Dirceu, Cartas Chilenas, dois poemas avulsos e o poema épico À Conceição.

\footnotetext{
${ }^{13}$ Esse volume teve uma segunda edição em 1944 e uma terceira em 1961.

${ }^{14}$ Em nota intitulada "Razões da presente edição", o autor dá notícia de que a obra teve uma edição publicada em 1942 com erros: “A edição que fizemos das 'Obras Completas de Tomás Antônio Gonzaga', em 1942, em plena guerra, saiu com as imperfeições devidas a uma tão excepcional situação. Entre essas imperfeições avultava sobretudo a caótica numeração das poesias, que, tendo submetido a um critério possivelmente cronológico, apareciam agora na disposição antiga, mas numeradas à moderna. A incorporação de novos materiais ao espólio tradicional de Gonzaga - referimo-nos sobretudo às composições da Parte III, de 1812, e ao poema sôre a aclamação de D. Maria I - impôs naturalmente a necessidade de uma nova arrumação das suas poesias e até de nova titulação. O melhor critério, quanto a nós, é o da seriação cronológica, que tem a vantagem de conservar em geral a ordem antiga das Liras. A numeração seguida torna-se deste modo um ponto de refêrencia mais cômodo e menos complicado.“. RODRIGUES LAPA, 1957, P. XXXVII.
} 
Conclui-se que o processo de atribuição de autoria das liras continua em curso, conforme as pesquisas avançam. Isto vale não apenas do ponto de vista histórico e bibliográfico, mas também da análise comparativa dos textos e da visada crítica que se têm sobre eles. As várias decisões editoriais que alteraram a ordem inicial dos poemas dificultam o estudo de Marília de Dirceu, uma vez que não permitem a apreensão da obra como um livro formalmente unitário, cujas liras se apresentam encadeadas e cuja disposição possa ser avaliada criticamente.

Neste trabalho, utilizamos a edição da Nova Aguilar e nos restringimos às liras da primeira e segunda partes, mais conformes às primeiras edições. As liras da terceira parte, os sonetos e outras peças não foram consideradas. Os quadros a seguir mostram a correspondência entre esta edição e as primeiras edições de Marília de Dirceu. 
Quadro 1 - Cotejo de numeração das liras nas diferentes edições

A poesia dos inconfidentes (Ed. Nova Aguilar, 1996) - Parte 1

\begin{tabular}{|c|c|c|c|}
\hline & Primeiro verso & Primeira edição & $\mathrm{N}^{\mathrm{o}}$ na $1^{\mathrm{a}}$ ed \\
\hline $\mathrm{I}-1$ & Eu, Marília, não sou algum vaqueiro, & Tipografia Nunesiana, 1792 & 1 \\
\hline $\mathrm{I}-2$ & Pintam, Marília, os Poetas & Tipografia Nunesiana, 1792 & 2 \\
\hline $\mathrm{I}-3$ & De amar, minha Marília, a formosura & Tipografia Nunesiana, 1792 & 3 \\
\hline $\mathrm{I}-4$ & Marília, teus olhos & Tipografia Nunesiana, 1792 & 4 \\
\hline $\mathrm{I}-5$ & Acaso são estes & Tipografia Nunesiana, 1792 & 5 \\
\hline $\mathrm{I}-6$ & Oh! quanto pode em nós a vária Estrela! & Tipografia Nunesiana, 1792 & 6 \\
\hline $\mathrm{I}-7$ & Vou retratar a Marília, & Tipografia Nunesiana, 1792 & 7 \\
\hline $\mathrm{I}-8$ & Marília, de que te queixas? & Tipografia Nunesiana, 1792 & 8 \\
\hline $\mathrm{I}-9$ & Eu sou, gentil, Marília, eu sou cativo; & Tipografia Nunesiana, 1792 & 9 \\
\hline $\mathrm{I}-10$ & Se existe um peito, & Tipografia Nunesiana, 1792 & 10 \\
\hline $\mathrm{I}-11$ & Não toques, minha Musa, não, não toques & Tipografia Nunesiana, 1792 & 11 \\
\hline $\mathrm{I}-12$ & Topei um dia & Tipografia Nunesiana, 1792 & 12 \\
\hline $\mathrm{I}-13$ & Oh! quantos riscos, & Tipografia Nunesiana, 1792 & 13 \\
\hline $\mathrm{I}-14$ & Minha bela Marília, tudo passa; & Tipografia Nunesiana, 1792 & 14 \\
\hline $\mathrm{I}-15$ & A minha bela Marília & Tipografia Nunesiana, 1792 & 15 \\
\hline $\mathrm{I}-16$ & Eu, Glauceste, não duvido & Tipografia Nunesiana, 1792 & 16 \\
\hline $\mathrm{I}-17$ & Minha Marília, & Tipografia Nunesiana, 1792 & 17 \\
\hline I-18 & Não vês aquele velho respeitável, & Tipografia Nunesiana, 1792 & 18 \\
\hline I-19 & Enquanto pasta alegre o manso gado, & Tipografia Nunesiana, 1792 & 19 \\
\hline $\mathrm{I}-20$ & Em uma frondosa & Tipografia Nunesiana, 1792 & 20 \\
\hline $\mathrm{I}-21$ & Não sei, Marília, que tenho, & Tipografia Nunesiana, 1792 & 21 \\
\hline $\mathrm{I}-22$ & Muito embora, Marília, muito embora & Tipografia Nunesiana, 1792 & 22 \\
\hline $\mathrm{I}-23$ & Num sítio ameno, & Tipografia Nunesiana, 1792 & 23 \\
\hline $\mathrm{I}-24$ & Encheu, minha Marília, o grande Jove & Tipografia Nunesiana, 1792 & 24 \\
\hline $\mathrm{I}-25$ & O cego Cupido um dia & Tipografia Nunesiana, 1792 & 25 \\
\hline I-26 & O destro Cupido um dia & Tipografia Nunesiana, 1792 & 26 \\
\hline $\mathrm{I}-27$ & Alexandre, Marília, qual o rio, & Tipografia Nunesiana, 1792 & 27 \\
\hline $\mathrm{I}-28$ & Cupido, tirando & Tipografia Nunesiana, 1792 & 28 \\
\hline I- 29 & O tirano amor risonho & Tipografia Nunesiana, 1792 & 29 \\
\hline $\mathrm{I}-30$ & Junto a uma clara fonte & Tipografia Nunesiana, 1792 & 30 \\
\hline I-31 & Minha Marília, & Tipografia Nunesiana, 1792 & 31 \\
\hline I-32 & Numa noite, sossegado, & Tipografia Nunesiana, 1792 & 32 \\
\hline I-33 & Pega na lira sonora, & Tipografia Nunesiana, 1792 & 33 \\
\hline
\end{tabular}


Quadro 2 - Cotejo de numeração das liras nas diferentes edições de Marília de Dirceu - Parte 2

\begin{tabular}{|c|c|c|c|}
\hline & Primeiro verso & Primeira edição & $N^{o}$ na $1^{a}$ ed. \\
\hline II-1 & Já não cinjo de loiro a minha testa, & Oficina Nunesiana, 1799 & 1 \\
\hline II-2 & Esprema a vil calúnia muito embora, & Oficina Nunesiana, 1799 & 2 \\
\hline II-3 & Sucede, Marília bela, & Oficina Nunesiana, 1799 & 3 \\
\hline II-4 & Já, já me vai, Marília, branquejando & Oficina Nunesiana, 1799 & 4 \\
\hline III-5 & Os mares, minha bela, não se movem; & Oficina Nunesiana, 1799 & 5 \\
\hline II-6 & De que te queixas, & Oficina Nunesiana, 1799 & 6 \\
\hline II-7 & Meu prezado Glauceste, & Oficina Nunesiana, 1799 & 7 \\
\hline III-8 & Eu vejo, ó minha bela, aquele Númen, & Oficina Nunesiana, 1799 & 8 \\
\hline III-9 & A estas horas & Oficina Nunesiana, 1799 & 9 \\
\hline III-10 & Arde o velho barril, arde a cabeça, & Oficina Nunesiana, 1799 & 10 \\
\hline II-11 & Se acaso não estou no fundo Averno, & Oficina Nunesiana, 1799 & 11 \\
\hline II-12 & Ah! Marília, que tormento & Oficina Nunesiana, 1799 & 12 \\
\hline II-13 & Vês, Marília, um cordeiro & Oficina Nunesiana, 1799 & 13 \\
\hline II-14 & Alma digna de mil Avós Augustos! & Oficina Nunesiana, 1799 & 14 \\
\hline III-15 & Eu, Marília, não fui nenhum Vaqueiro, & Oficina Nunesiana, 1799 & 15 \\
\hline II-16 & Vejo, Marília, & Oficina Nunesiana, 1799 & 16 \\
\hline II-17 & Dirceu te deixa, ó bela, & Oficina Nunesiana, 1799 & 17 \\
\hline II-18 & Não molho, Marília, & Oficina Nunesiana, 1799 & 18 \\
\hline II-19 & Nesta triste masmorra, & Oficina Nunesiana, 1799 & 19 \\
\hline III-20 & Se me visses com teus olhos & Oficina Nunesiana, 1799 & 20 \\
\hline III-21 & Que diversas que são, Marília, as horas, & Oficina Nunesiana, 1799 & 21 \\
\hline III-22 & Por morto, Marília, & Oficina Nunesiana,1799 & 22 \\
\hline II-23 & Não praguejes, Marília, não praguejes & Oficina Nunesiana, 1799 & 23 \\
\hline III-24 & Eu vou, Marília, vou brigar co'as feras! & Oficina Nunesiana, 1799 & 24 \\
\hline III-25 & Minha Marília, & Oficina Nunesiana,1799 & 25 \\
\hline III-26 & Aquele a quem fez cego a Natureza, & Oficina Nunesiana, 1799 & 26 \\
\hline III-27 & A minha amada & Oficina Nunesiana, 1799 & 27 \\
\hline III-28 & Detém-te, vil humano, & Oficina Nunesiana, 1799 & 28 \\
\hline III-29 & Eu descubro procurar-me & Oficina Nunesiana, 1799 & 29 \\
\hline II-30 & O Pai das Musas, & Oficina Nunesiana, 1799 & 30 \\
\hline III-31 & Roubou-me, ó minha Amada, a sorte ímpia & Oficina Nunesiana, 1799 & 31 \\
\hline II-32 & Se o vasto mar se encapela, & Oficina Nunesiana, 1799 & 32 \\
\hline III-33 & Morri, ó minha Bela; & Oficina Nunesiana, 1802 & 33 \\
\hline III-34 & Vou-me, ó Bela, deitar na dura cama, & Oficina Nunesiana, 1802 & 34 \\
\hline III-35 & Se lá te chegarem & Oficina Nunesiana, 1802 & 35 \\
\hline III-36 & Não hás de ter horror, minha Marília, & Oficina Nunesiana, 1802 & 36 \\
\hline III-37 & Meu sonoro Passarinho, & Oficina Nunesiana, 1802 & 37 \\
\hline III-38 & Eu vejo aquela Deusa, & Tipografia Lacerdina, 1811 & II-38 \\
\hline
\end{tabular}


Além do chamado "problema das edições", alguns outros fatores foram responsáveis pela "tempestade perfeita" que se deu após a publicação da obra Marília de Dirceu. A combinação de circunstâncias históricas, políticas, biográficas e literárias levou a uma moldagem da recepção crítica da obra atribuída a Gonzaga e transportou seu suposto autor a um lugar no imaginário popular que perdura ainda hoje. São imagens estereotipadas dos "ternos versos de amor" do poeta apaixonado, afastado à força de sua amada, preso e exilado por sua participação na Conjuração Mineira.

Uma imagem física do poeta consagrou-se: jovem, esguio, de longos cabelos negros desgrenhados descendo pelas costas, com a camisa branca e uma pena na mão, que conviria talvez ao poeta britânico Lord Byron (1788-1824). A representação que a história conservou de Gonzaga foi publicada na edição de Joaquim Norberto, em 1862. A litografia baseia-se num retrato a óleo de Maximiano Mafra (Tomás Gonzaga no cárcere), exposto no salão de 1844 no Rio de Janeiro, que, segundo o pintor, tinha saído de sua imaginação (Figura 2). Eduardo Frieiro contesta a veracidade desta imagem, afirmando que o poeta era "loiro e cheio de corpo"15. Já no século XX, ilustrações a bico de pena, assinadas pelo artista Seth, que compuseram a edição de $O$ amor infeliz de Marília e Dirceu ${ }^{16}$, pretendiam recontar a história do poeta e de sua infeliz Marília, que aparece em várias idades: jovem, madura e idosa, como numa história em quadrinhos ambientada em Vila Rica.

A apropriação da figura do poeta passou do campo da imagem, da representação física, para a materialidade do corpo de Gonzaga. Com o propósito de "reunir as cinzas dos amantes que nem o tempo nem a morte poderiam separar", o historiador e então ministro Augusto de Lima Jr. encaminhou, em abril de 1936, carta ao presidente Getúlio Vargas solicitando a repatriação dos despojos dos inconfidentes. O argumento final do autor para tal pedido ao presidente é de conteúdo nacionalista e sentimental:

\footnotetext{
Vós, Sr. Dr. Getúlio Vargas, amigo dos escritores e dos artistas, compreendereis a razão deste pedido que vos dirigimos e vossas próprias mãos deverão depositar, na Sepultura $n^{\circ} 11$ da Matriz de Antônio Dias, as escassas cinzas que forem encontradas no chão da Sé de Moçambique. E Deus Nosso Senhor há de permitir que, nesse dia, Dirceu e Marília desçam aos céus de Ouro Preto, para abençoar o brasileiro ilustre que, com sua autoridade, tornou possível o sonho do poeta: Depois que nos ferir a mão da Morte/ Ou seja neste monte, ou noutra serra,'/Nossos corpos terão, terão a sorte, / De consumir os dois a mesma terra'. ${ }^{17}$
}

\footnotetext{
${ }^{15}$ FRIEIRO, Eduardo. 1981, p. 73.

${ }^{16}$ LIMA JÚNIOR, Augusto de. O amor infeliz de Marília e Dirceu. Rio de Janeiro: A Noite, 1937.

${ }^{13}$ LIMA JÚNIOR, op. cit, p. 15.
} 
O pedido do ministro foi prontamente atendido pelo presidente com a publicação do Decreto n. 756-A, do Ministério da Educação: “Art. $1^{\circ}$ - Fica autorizado o Ministro da Educação e Saúde Pública, em combinação com o das Relações Exteriores e o da Marinha, a providenciar para que, obtidas as permissões necessárias de quem de direito, sejam exumadas de suas sepulturas nas terras de degredo e transportadas para o Brasil as cinzas dos Inconfidentes, cujos nomes constam da sentença de 20 de abril de 1792 da Alçada Régia no Rio de Janeiro. Art. $2^{\circ}$ - À cidade de Ouro Preto ficará confiada a guarda desses despojos que, depositados em monumento receberão o culto cívico nacional”.

Segundo o jornalista Marcelo Resende (RESENDE, 1998),

O decreto permitiu a Augusto de Lima Jr. todas as facilidades para localizar e solicitar, em nome do país, o repatriamento dos restos mortais dos inconfidentes, em vários cantos do mundo, e a fundação do Museu da Inconfidência, na antiga Casa de Câmara e Cadeia de Vila Rica, que culminou em grande solenidade cívica na cidade de Ouro Preto, no ano de 1942. O desejo inicial do autor de juntar os restos mortais de Marília e Dirceu não se deu como havia declarado na carta enviada ao presidente. Os restos mortais de Tomás Antônio Gonzaga não foram encaminhados à sepultura n. 11 da Matriz de Nossa Senhora da Conceição. As cinzas trazidas de Moçambique chegaram de trem, seguiram cortejo solene pela cidade de Ouro Preto e foram depositadas em Panteão Cívico criado no Museu da Inconfidência para os Heróis da Pátria. Apenas em 1955, foi criado no Museu da Inconfidência um espaço na antessala do Panteão dedicado às mulheres. Os restos mortais de Marília de Dirceu ${ }^{18}$ foram exumados de seu túmulo e levados para sepultura criada naquele espaço dedicado à memória nacional da Inconfidência Mineira e ao seu lado foi criada também sepultura simbólica dedicada a Bárbara Eliodora. ${ }^{19}$

Mas o imbróglio não terminou aí. Os restos mortais ali depositados não seriam de Gonzaga:

Em 1936, o Brasil entra em negociações com o governo de Portugal para recolher os restos mortais dos inconfidentes exilados. Uma equipe chefiada pelo historiador Augusto de Lima Jr. parte no navio Bagé em 24 de dezembro. Lima Jr., na África, revira muitos túmulos e recolhe o que encontra. Inclusive os ossos de Tomás Antônio Gonzaga de Magalhães, neto do poeta, falecido em 1856.

O "Magalhães", aparentemente, passou despercebido pela missão getulista e seus restos estariam agora no Museu da Inconfidência de Ouro Preto, fortalecendo, segundo alguns historiadores, um "mito da inconfidência" montado por Vargas. O primeiro aviso do possível engano

\footnotetext{
${ }^{18}$ É interessante notar como a fusão da figura de Marília de Dirceu com a personagem histórica Maria Doroteia de Seixas ocorreu no próprio texto do jornalista, ao mencionar que 'Marília' fora enterrada no Panteão Cívico do Museu da Inconfidência.

${ }^{19}$ RESENDE, Marcelo. Tomás Antônio Gonzaga continua exilado na África. Folha de S.Paulo, 14/01/1998. Disponível em: https://www1.folha.uol.com.br/fsp/ilustrad/fq140103.htm. Acesso em: 14/01/1998.
} 
foi uma denúncia do trineto do poeta em 1955. A notícia chegou a Portugal dois anos depois, quando foi publicada em um jornal do país. (RESENDE, 1998)

De qualquer forma, o noivado com Doroteia de Seixas no período em que viveu em Vila Rica e o suposto envolvimento do poeta na Inconfidência Mineira, que o levou à prisão, à condenação por crime de lesa-majestade e ao degredo em Moçambique, foram os ingredientes básicos do processo que transformou o português Tomás Antônio Gonzaga num mito da literatura brasileira e numa espécie de herói nacional. Como explica Alexandre Eulálio,

a sua imagem legendária formou-se principalmente aqui, na consciência das nossas gerações românticas, junto com a das grandes figuras nacionais. Projeta-se, com esse perfil, não só na história da nossa formação literária, mas também na história da construção da pátria. ${ }^{20}$

Considerando as liras mais fidedignas do que um ensaio biográfico, Varnhagen assim se expressou, em 1850.

E por tal forma temos esta conviç̧ão que ora mesmo não ousamos dar um passo sem primeiro correr de novo os olhos pelas 38 lyras da $2^{\mathrm{a}}$ parte. Assim o acabámos de executar, e tal é a commoção de que nos sentimos ainda possuidos que nos treme a mão ao escrever estas linhas. Estamos profundamente convencidos de que Gonzaga foi martyr da prognosticada sedição, e que até era a ella inteiramente alheio. Assim o protestou bem solemnemente aos juizes, e com todo o vigor d 'alma o protesta nos seus versos a si mesmo, á sua Marília, e ao mundo! $!^{21}$

Esse longo processo foi construído por historiadores, editores e críticos ao longo do século XIX e foi paralelo à apropriação da obra, segundo critérios românticos adaptados a um público leitor burguês. Conforme esclareceu o estudioso Joaci Furtado,

a biografia oitocentista de Gonzaga (...) é indissociável de suas liras quando não tributária, mais exatamente da leitura que o Romantismo fez destas últimas. O eterno cantor de Marília explica o inconfidente do mesmo modo como seu desafortunado idílio com Maria Joaquina aquece a contemplação de seus versos pela sensibilidade romântica: (...) GonzagaDirceu é prisioneiro de seu drama amoroso. ${ }^{22}$

\footnotetext{
${ }^{20}$ EULALIO, Alexandre. Biografia. In: GONZAGA, Tomás Antônio, op. cit.

${ }^{21}$ VARNHAGEN, Francisco A. de. Florilégio da poesia brasileira. Lisboa: Imprensa Nacional, 1850. Rio de Janeiro: Academia Brasileira de Letras, 1946, t. 2. p. 60.

${ }^{22}$ FURTADO, Joaci F. Uma república de leitores: história e memória na recepção das Cartas chilenas (1845-1989). São Paulo: Hucitec, 1997. p. 103.
} 
A construção do mito não se deveu apenas a especialistas. Em 1875 Castro Alves publicou o drama histórico Gonzaga ou a revolução de Minas, exaltando a figura heroica do poeta. A peça foi recitado e aclamada publicamente.

Com o declínio das convenções românticas e a proclamação da República, surgiu uma nova apreciação do autor e da obra. Já não se tratava do infeliz cantor de Marília, mas do literato que forjou a nacionalidade, o mártir da Independência.

O crítico Sílvio Romero referiu-se ao "naturalismo" de Gonzaga, ao comentar a lira I,19: "Isto é de um naturalismo completo e perfeito; é a pintura da vida. Os realistas de hoje têm, quem tal diria? um antecessor no clássico e pastoril Dirceu", (ROMERO, 1902, p. 244). Nas liras da segunda parte, Romero destacou que "o talento de Gonzaga era de natureza objectiva; no cárcere, pungido pelo sentimento, sempre em meio da descripção de seus pezares, vem uma scena da natureza mitigar-lhe as penas e modificar o escuro do quadro". Naturalista enquanto poeta, Gonzaga, do ponto de vista político, teria tido o "sonho revolucionário",23:

Sim; o poeta teve o sonho revolucionário; este grande titulo deve religiosamente ser-lhe conservado pela historia. Não se busquem para elle rehabilitações fallaciosas, inspiradas por meras adulações monarchicas. Dirceu quiz o levante, quíz á republica, quiz a independencia. E' por isso que elle tem sido e continuará a ser um dos guias immortaes do povo brasileiro. $^{24}$

Por ocasião da fundação da Academia Brasileira de Letras, intelectuais e literatos instituíram uma cadeira destinada a Gonzaga, a de número 37. Não poucos acadêmicos consideraram a homenagem destinada mais ao herói da Pátria que ao poeta e menosprezaram com convicção a qualidade dos seus versos. Na mesma cadeira na ABL tomou posse o ficcionista Alcântara Machado que, em seu discurso, afirmou que

Gonzaga era um poeta que tinha os pés na Lusitânia, a cabeça no Olimpo e o coração pulsando por uma dama, por ele posta no ambiente estrangeiro dos seus versos.

\footnotetext{
23 “Gonzaga nos depoimentos de seus collegas de infortúnio foi mais ou menos poupado, e elle proprio negou até a ultima que tivesse tomado parte na conjuração; assim o declarou aos juizes em suas poesias a Marilia. Por taes motivos, Varnhagen é levado a crer que elle fosse estranho á Inconifidencia. Não é esta a verdade que sahe dos factos; o insigne poeta não precisa dessa justificativa posthuma, falsa e insidiosa. Não ha razões serias para arredar de sua fronte a aureola de patriota sanctificado pelo sofrimento". In ROMERO, Sílvio. História da literatura brasileira, $2^{\mathrm{a}}$ edição melhorada pelo autor, t. 1. Rio de Janeiro: H. Garnier, 1902, p. 250.

${ }^{24}$ Idem, ibidem.
} 
acrescentando também ser "o seu bucolismo, postiço, importado, como ele o fora e sua cultura". 25

Em 1935, o presidente Getúlio Vargas tomou posse na Academia Brasileira de Letras, na cadeira que tinha como patrono Gonzaga. Seu discurso de posse enalteceu o homem, partícipe da Inconfidência, e desmereceu o poeta:

O que singularizou a figura daquele Desembargador do século XVIII não foi certamente a inovação literária, a inspiração de grandes voos ou a criação linguística, como aconteceu com Dante e Camões. A sua lírica é similar à de todos os poetas do tempo. (...) Não foi, por consequência, essa literatura de amores infelizes, tão comum em tantos autores da época, o que elevou a herói o patrono desta cadeira. A projeção excepcional da personalidade do cantor de Marília resultou da sua atuação política, da sua participação num acontecimento que objetivava emancipar a grande terra brasileira, ausente na obra do poeta e presente na existência do homem. ${ }^{26}$

A versão fantasiosa de que o poeta teria enlouquecido no degredo ocupou também corações e mentes do público e de estudiosos. Apartado da amada, Gonzaga teria ensandecido. Essa versão foi desautorizada com a descoberta de documentos que demonstram que o poeta se casou, no ano seguinte à chegada em solo africano, com Juliana de Sousa Mascarenhas, com quem teve dois filhos, Ana Mascarenhas Gonzaga e Alexandre Mascarenhas Gonzaga. ${ }^{27}$ A narrativa de que o poeta abdicara de escrever também foi por terra com a descoberta do manuscrito de um poema épico intitulado À Conceição, que teria sido composto em Moçambique.

\footnotetext{
${ }^{25}$ Apud OLIVEIRA, Almir de. Gonzaga e a Inconfidência Mineira. Belo Horizonte: Itatiaia, 1985, p. 26-27.

${ }^{26}$ OLIVEIRA, Almir de. Idem, ibidem, p. 32.

${ }^{27}$ Sua filha Ana casou-se em segundas núpcias, em 1828, com Adolfo João Pinto de Magalhães, com quem teve três filhos: Cândida Gonzaga Pinto de Magalhães, Tomás Antônio Gonzaga de Magalhães e Adolfo João Pinto de Magalhães. Cândida e Adolfo João Adolfo Pinto deixaram descendência.
} 


\subsection{Um público presente}

Desde a primeira edição, o livro alcançou notável acolhida do público leitor. A Gazeta de Lisboa anunciou, em 10 de novembro de 1792: "Sahio à luz: Marilia de Dirceo, primeira parte das Poesias lyricas de T.A.G.”. E, em 29 de junho de 1792, uma notícia no mesmo jornal anunciava uma nova tiragem da mesma edição: "Sahirão à luz: As Lyras do Doutor Thomas Antônio Gonzaga, cuja obra tem merecido geral aplauso". ${ }^{28}$ Cabe notar que, além do geral aplauso do público, o livro é apresentado como "primeira parte" das poesias líricas, o que indica a existência das liras da segunda parte ou, ao menos, a intenção de que fossem elaboradas e publicadas.

Do ponto de vista de seus leitores, Marília de Dirceu sempre foi obra popular: "Nenhuma obra em português, a não ser o Camões, tem tido mais edições neste século". ${ }^{29}$ $\mathrm{O}$ fato de as liras terem sido musicadas constitui-se em outro fator de sua divulgação. “Diversos compositores, populares e eruditos, puseram em música boa parte das Liras. Prova eloquente do alcance destes versos que traziam um não-sei-quê de novo e começaram a ser cantados em serestas de esquina e árias de salão”, explica Alexandre

\footnotetext{
${ }^{28}$ As nota publicadas na Gazeta de Lisboa, pelas edições de 1792 ( $1^{\mathrm{a}}$ parte $)$ e 1799 ( $2^{\mathrm{a}}$ parte $)$ foram apontadas por LEY (1927, p. 425 e 429) : "Edição original das lyras de Thomaz Antonio Gonzaga, que por muito tempo ficou inteiramente desconhecida dos bibliographos. embora seu aparecimento tivesse sido noticiado na Gazeta de Lisboa, de 10 de Novembro de 1792, Segundo supplemento: 'Sahio á luz : Marilia de Dirceo, primeira parte das Poesias lyricas de T. A. G. — Vende-se por 240 reis na loja da Gazeta, e na do Livreiro da Academia" "; "Da Gazeta de Lisboa, de 22 de Novembro de 1799, supplemento, extrahimos a seguinte noticia referente a esta edição: 'Sahio á luz: Marilia de Dirceo, obra Poética, que tem merecido huma geral acceitação, 2 vol. de 8o, seu preço 480 reis. Achase na loja da Gazeta.' “

${ }^{29}$ Apud GONZAGUIANA, p. 422. Gaudie Ley se refere à afirmação de Francisco Adolfo Varnhagen, em 1850. Pode-se cogitar a hipótese de Varnhagen referir-se ao Camões de Almeida Garrett, obra publicada em 1825, que conseguiu também numerosas edições. De toda maneira, a formulação de Varnhagen foi depois muitas vezes repetida, o que faz com que, por anacronismo crescente, torne-se cada vez mais imprecisa. Joaquim Norberto repete em 1862 que "muitas edições conta o poema lírico de G.; é talvez depois de Camões o poeta da língua portuguesa que se pode ufanar de tamanha honra" (op. cit. p. 7). Já no séc. XX, Otto Maria Carpeaux reitera que "o grande número de edições permite afirmar que Gonzaga é, depois de Camões, o poeta lírico mais lido da língua portuguesa" (CARPEAUX, Otto Maria. Pequena bibliografia crítica da literatura brasileira, Rio de Janeiro, 1955, p. 55), no que foi secundado por Waltensir Dutra, para quem "Gonzaga é o autor do livro de poemas mais lido na língua portuguesa, depois de Os lusíadas" (O arcadismo na poesia lírica, épica e satírica. In COUTINHO, Afrânio (dir.), A literatura no Brasil, v. I, Rio de Janeiro: Sul Americana, 1969, p. 324).
} 
Eulálio. ${ }^{30}$ Uma nota assinada por Emílio Zaluar na Revista Popular, em 1862, atesta a imensa penetração da obra, nos dois lados do Atlântico.

\begin{abstract}
As queixas ingênuas e sentidas do poeta, que tantas vezes ouvi nos serões de minha infância repetir na intimidade do lar, e aprendi de cor na idade em que melhor começava a compreendê-las, vim escutá-las a duas mil léguas de distância em todos os lábios brasileiros, como se a graciosa religião da poesia fosse mais um laço de fraternidade para vincular os dois povos $(\ldots){ }^{31}$
\end{abstract}

O interesse do público europeu pelas liras de Tomás Gonzaga também se evidencia pelas várias traduções da obra, sobretudo no século XIX. Marília de Dirceu foi traduzida para o francês por E. Monglave e P. Cholas (Marilie, chants elegiaques de Gonzaga, Paris, 1825) "precedida de uma notícia da origem e progresso da língua portuguesa e da notícia biográfica do autor com as costumadas inexatidões",32 para o italiano por G. V. Buscalla (Marilia de Dirceo: lire tradotte, Turim, 1844), "feita em igual número de versos e na mesma metrificação e reimpressa em 1885, também nas duas primeiras partes", ${ }^{33}$ para o castelhano por D. Henrique Vedia, para o alemão por Ifand. Sacramento Blake menciona ainda a existência de uma tradução para o inglês e uma curiosa versão latina empreendida pelo dr. A. de Castro Lopes, feita para uso das escolas secundárias do império, publicada no Rio de Janeiro em 1866, precedida de uma carta proemial do conselheiro J. Feliciano de Castilho e que alcançou uma segunda edição em 1887, precedida de um juízo crítico do barão de Paranapiacaba. Consta ainda uma tradução de Puchkin para o russo, que verte um dos chants elegiaques em versos. Uma tradução contemporânea para o espanhol foi realizada pelo pesquisador Jorge Antonio Ruedas de la Serna, editada em 2002.

\title{
1.3. Maria Joaquina Doroteia de Seixas
}

O mito do poeta enamorado, separado à força de sua amada, que emoldurou Gonzaga, teve uma contrapartida no mito da amada Marília. Nossa crítica elogia Marília

\footnotetext{
${ }^{30}$ EULALIO, Alexandre. Verso e reverso de Gonzaga. Op. cit., p. 7. Algumas árias podem ser ouvidas em gravação Marília de Dirceu. Ana Maria Keffer (voz), Gisela Nogueira (viola, guitarra) e Edelton Gloeden (guitarra). Selo Tacape. Série Memória Música Minas Gerais. 1985.

${ }^{31}$ ZALUAR, Emilio. Revista Popular. Rio de Janeiro, Garnier, abr.-jun. 1862. T. 14. Apud LEY, Emmanuel Eduardo Gaudie. Gonzagueana da Biblioteca Nacional, op. cit. p. 446.

${ }^{32}$ BLAKE, Sacramento. Dicionário bibliográfico brasileiro. p. 280.

${ }^{28}$ Idem, ibidem.
} 
como "a verdadeira namorada". O estudioso Antônio Candido, reconhecendo em Marília um dos únicos mitos femininos de nossa literatura, incorpora a fidelidade ao tema de Marília no "amor por Doroteia de Seixas". A figura histórica de Maria Joaquina Doroteia de Seixas (1767-1853) passou ao segundo plano, transformando-se numa espécie de suporte para tornar verossímil a Marília dos poemas - a "verdadeira" Marília.

Monografia recente (2014) de Ana Cristina Magalhães Jardim ${ }^{34}$ rastreou o mito de Marília de Dirceu, desde seu aparecimento com a primeira edição do livro atribuído a Gonzaga, em 1792, até 1889, quando foi proclamada a República. Apoiada em fontes documentais, ${ }^{35}$ Ana Jardim traçou um perfil biográfico de Maria Joaquina Doroteia de Seixas, contextualizando sua vida em Minas Gerais dos séculos XVIII e XIX. A vida de Doroteia de Seixas foi semelhante à de outras mulheres de sua condição social, formada pela elite católica branca de Vila Rica. Doroteia tinha boa situação financeira, levou uma vida ativa, gozou de boa saúde e dispôs dos bens da família, ao morrer solteira, aos 86 anos, a d. Francisca de Paula Manso de Seixas, sobrinha que vivia em sua companhia, e a Anacleto Teixeira de Queiroga, residente no Rio de Janeiro. A hipótese de Anacleto ser seu filho ilegítimo com o capitão Teixeira de Queiroga chegou a ser aventada, mas não foi levada adiante por pesquisadores. ${ }^{36}$

\footnotetext{
${ }^{34}$ JARDIM, Ana Cristina M. O mito de Marília de Dirceu - 1792 a 1889: aspectos da construção e da apropriação de heróis românticos e o processo de formação da Nação Brasileira. Dissertação (Mestrado em História), Instituto de Ciências Humanas e Sociais - UFOP, Mariana, 2014.

${ }^{35}$ Os documentos consultados foram: a) seu registro de batismo; b) os Autos de Devassa da Inconfidência Mineira; c) a entrada, profissão e expensa de Ministra da Ordem Terceira de São Francisco de Assis de Ouro Preto; d) o pedido de emancipação; e) as atas da Câmara Municipal de Ouro Preto com requerimento de Maria Doroteia; f) o Testamento de Maria Doroteia e f) os jornais do Rio de Janeiro no século XIX. Segundo JARDIM, 2014, p. 30.

36، Maria Doroteia Joaquina de Seixas teve filhos? Bem, os que gostavam de zelar pela memória da musa de Gonzaga não admitiam essa ideia e diziam que o filho atribuído a Marília, na realidade, era de sua irmã mais nova, Emereciana, com o tenente-coronel Manoel Teixeira Queiroga. 'Conta-se que, a fim de proteger o nome da jovem - que dera à luz secretamente numa fazenda -, a família executou o plano de abandonar o recém-nascido como enjeitado à porta de gente amiga, a fim de facilitar a adoção da criança por Marília. Desse modo viveria Anacleto junto da tia e da mãe, ficando salvas as aparências. E assim foi feito" (Lúcia M. de Almeida). Há os que não acreditavam em versões tão românticas e aceitavam o fato que Maria Doroteia teve filhos. O viajante inglês Richard Burton registrou nos seus escritos sobre Ouro Preto as estórias maledicentes que corriam na cidade sobre Marília: "três filhos louros, de olhos azuis, oriundos do concubinato com um certo doutor Queiroga, ouvidor de Ouro Preto"'. O Jornal do Comércio, de 18/01/ 1893, publicou o seguinte telegrama: 'Ouro Preto, 17 de janeiro. Faleceu o major Pedro Queiroga, neto de Marília de Dirceu, vítima de lesão cardíaca. Era oficial maior aposentado na Secretaria do Interior, dotado de inteligência e por todos respeitado'. No diário de viagem de d. Pedro II, existe o seguinte relato: '19 de abril... Segui até o chafariz da Ponte para ver a neta de Marília de Dirceu (sic), mulher de Carlos de Andrade, que fica perto. Apareceu à janela. É elegante e graciosa, porém não é beleza, tem ares de inteligente'.” In: Senac Minas Gerais. Descubra Minas. 2019. Acesso em: out. 2019.
} 
A construção do mito Marília de Marília de Dirceu seguiu um roteiro próprio, em que historiadores se basearam numa figura idealizada que extraíram dos poemas - a noiva casta e belíssima que, separada brutalmente de seu amado, por ele suspirou até o fim de seus dias. O papel atribuído a Doroteia de Seixas no processo de construção da imagem dos heróis que viveram no século XVIII e na conformação da identidade e da nacionalidade brasileira está ligado ao papel atribuído a Tomás Antônio Gonzaga. Não se trata, porém, da personagem histórica, mas de uma figura literária, cunhada pela obra lírica:

Precisamos ter em vista que a inclusão de Maria Doroteia no processo acima referido se dá por meio da personagem lírica Marília de Dirceu e que o que a faz ser reconhecida como musa da Inconfidência Mineira é sua ligação com Tomás Antônio Gonzaga, um dos envolvidos no movimento. ${ }^{37}$

O mito de Marília como musa da Inconfidência acompanhou a trajetória do mito romântico de Tomás Antônio Gonzaga, construído no século XIX. Teixeira e Sousa, autor do romance Gonzaga ou a Conjuração do Tiradentes, publicado nos anos de 1848 e 1851, contribuiu para a construção do "casal de sonhos", baseando as falas dos supostos personagens históricos nos textos das liras. No entanto, a entrada definitiva de Doroteia de Seixas/Marilia de Dirceu para o panteão dos mitos brasileiros foi sua inclusão no volume Brasileiras Célebres, publicado em 1862, organizado e prefaciado pelo historiador Joaquim Norberto de Souza. ${ }^{38}$ Os únicos dados biográficos de Doroteia de Seixas mencionados por Joaquim Norberto são as datas de seu nascimento e seu falecimento. O historiador justifica sua importância modelar na sociedade brasileira pelos "dotes, que lhe dera o Céu, e pela paixão, que soube inspirar ao mais terno dos poetas de nossa língua". 39

O mesmo Joaquim Norberto havia publicado uma obra pretensamente apócrifa da obra Dirceu de Marília, em $1845 .^{40}$. No prefácio sugeria, indireta e maliciosamente, que a autoria talvez pudesse ser de Doroteia de Seixas:

\footnotetext{
${ }^{37}$ JARDIM, Ana Cristina M., op. cit. p.134.

${ }^{38}$ SILVA, Joaquim Norberto de S. Brasileiras célebres. Reed. Brasília: Senado Federal, 2004. A primeira edição foi publicada em 1945.

39 "Pôde dona Maria Joaquina Doroteia de Seixas sobreviver-lhe por tanto tempo, esquecida do mundo, e tão-somente alimentada de saudades; mas a vida, que ao cabo tornou-se-lhe octogenária, assaz concorreu para que se visse cercada de admiração; traíram-na a publicação daquelas tão lidas e delicadas liras, de que foi tão condigno assunto. Proclamada bela e formosa, cantado por um poeta, que se tornara eminentemente célebre pelo infortúnio do seu exílio, ela viu todos esses louvores, que quase sempre têm um não-sei-quê de exagerados, derramados às mãos cheias pelo seu tão afamado livro, traduzido nas principais línguas deste século".

${ }^{40}$ Rio de Janeiro, J. E. S. Cabral, 1845. A segunda edição foi publicada em 1862.
} 
DIRCEU DE MARÍLIA

LIRAS Atribuídas a Senhora DMJD de S (natural de Vila Rica)

(...)

SOBRE AS PRESENTES LIRAS

Não serei eu que afirmarei ou negarei a autenticidade da presente coleção de Liras extraídas de uma cópia que se me afirma ter sido tirada de manuscritos autênticos, cuja ortografia não pude conservar que não mo permitiu a brevidade do tempo que tinha a dispor. Apócrifas ou originais, completam elas a história dos amores e saudades desses amantes desgraçados que a poesia começou por celebrar e que os homens acabaram por imortalizar; os nomes de Marília e Dirceu se tornaram populares em todo o Brasil, e hoje retumbam pela Europa e América, e um dia se unirão aos de Hero e Leandro, Safo e Faon, Heloísa e Abelardo, Inês e Pedro, Laura e Petrarca, e então serão populares em todo o mundo. Parece que foram elas escritas em Vila Rica e enviadas pela maior parte à cadeia pública do Rio de Janeiro; ao menos assim se depreende de sua leitura e ainda mais dos versos do poeta que vão em testa deste opúsculo como epígrafe: (...)

Niterói, agosto de 1845 J. Norberto de S. S. (grifos nossos)

Sabe-se que Doroteia de Seixas jamais foi consultada por historiadores e nunca houve registro de que tenha feito qualquer manifestação ou aparição pública, embora estivesse viva durante boa parte do processo de construção do mito 'Marília de Dirceu'. O papel mítico da personagem histórica é assim compreendido por Ana Jardim:

No caso de Maria Doroteia, ela protege [o herói] com sua nacionalidade
brasileira e cumpre a função de emprestar a Gonzaga uma brasilidade
que o autoriza a ser tratado como herói em busca da independência e da
nacionalidade brasileira. A Marília romântica, constrú́da pelos homens
do século XIX, se alinhou ao modo de escrever a história do período em
que "o episódio histórico em si, por mais importante que seja, não é
conservado na memória popular, e sua lembrança tampouco alimenta a
imaginação popular, salvo enquanto o episódio histórico particular
estiver próximo de um modelo mítico", como foi o caso de Marília e
Dirceu.

A exaltação da figura lendária de Marília não ocorreu apenas no século XIX. Em desagravo à honra de Maria Doroteia, pretensamente manchada por historiadores como Richard Burton e outros ${ }^{42}$. Thomas Brandão, primo de Maria Doroteia em quarto grau,

\footnotetext{
${ }^{41}$ JARDIM, Ana Cristina M., op. cit. p. 134.

${ }^{42}$ As afirmações que o antropólogo inglês Richard Burton fez ao registrar sua passagem por Ouro Preto e que motivaram o desagravo de Brandão reportam-se à suposta conduta moral de Doroteia de Seixas, após a prisão de Gonzaga: "Infelizmente para o romance, Heloísa foi infidelíssima a Abelardo, como Abelardo foi infiel à Heloísa. Os amantes que a 'morte não poderia separar' e cujos protestos de constância escritos foram inúmeros, separaram-se depois da descoberta da rebelião; isso é facilmente explicável: entre os inconfidentes,
} 
publica em 1932 um livro denominado Marília de Dirceu. Neste volume, o autor reafirma a beleza e a castidade da parenta, mantidas até seu último dia, o que comprova a longevidade do mito de Marília:

Muito mais tarde, os sinos dobraram a finados e a notícia da morte de D. Maria Doroteia Joaquina de Seixas espalhou-se rapidamente por Ouro Preto (...) Em branco caixão, engrinaldado de flores de laranjeira, uma velhinha de oitenta e cinco anos dormia o sono eterno. Finalizava Marília, nesse dia, sua existência, balbuciando entre as orações da agonia o nome adorado de Dirceu. ${ }^{43}$

Durante a ditadura civil e militar no país, os Correios lançaram a Série Mulheres Famosas do Brasil. A presença da personagem literária Marília de Dirceu nesse panteão, ao lado de outras figuras históricas enaltecidas pelo nacionalismo da época, corrobora a indiferenciação entre história e ficção. O selo com a estampa de Marília de Dirceu foi lançado em 11 de agosto de 1967. Marília aparece ao lado de Ana Néri (enfermeira que trabalhou na Guerra do Paraguai), Madre Joana Angélica (mártir da Independência), Anita Garibaldi (participante da Revolução Farroupilha), Maria Bárbara (devota que preferiu a morte a sofrer um estupro) e Damiana da Cunha (indígena caiapó que catequisou índios em Goiás). Interessante notar que faz parte desse panteão a também lendária Catarina Paraguaçu (esposa indígena de Diogo Caramuru), personagem da obra de Santa Rita Durão, Caramuru.

\subsection{Um tortuoso caminho crítico}

Estimada pelo público, louvada ou censurada pela crítica, atraente ou desconcertante para os estudantes, a obra até hoje faz parte do rol de "nossos clássicos". Continua sendo continuamente reeditada, integra o currículo escolar e as histórias literárias, é tema de concursos públicos e exames de acesso ao ensino universitário. Paradoxalmente, no entanto, as liras de Marília de Dirceu não possuem propriamente uma

falara-se sobre a necessidade de remover-se a cabeça do enérgico ajudante de ordens. Os dois tiveram, contudo, licença de se despedirem para sempre - e a cena foi dolorosa, segundo dizem. E ambos fizeram o diabo, depois disso. Um certo Dr. Queiroga, ouvidor de Ouro Preto, teve a honra de suplantar o poeta Gonzaga, mas não com ternura legalizada. Dele, D. Maria Dirceu, como era chamada, teve três fillhos: Dr. (M.A.) Anacleto Teixeira de Queiroga, D. Maria Joaquina e D. Doroteia, todos de olhos azuis e cabelos louros. Em Ouro Preto, ela é hoje conhecida como a Mãe do Dr. Queiroga”. In: BURTON, Richard F. Viagem do Rio de Janeiro a Morro Velho. Trad. David Jardim Jr. Belo Horizonte: Itatiaia, 1976 (1 $1^{\text {a }}$ ed. 1869). ${ }^{38}$ Apud JARDIM, op. cit., p. 71. 
tradição exegética. Uma quantidade expressiva de comentadores, críticos e historiadores debruçou-se sobre a obra e seu suposto autor, constituindo uma volumosa fortuna crítica. No entanto, grande parte desses trabalhos situa-se num terreno de disputa e apropriação da biografia e da obra de Gonzaga, criado no século XIX e que se perpetuou até a segunda metade do século XX.

Seja essa disputa literária, ideológica ou política, podemos afirmar que ela dificultou consideravelmente uma apreciação crítica consistente de Marília de Dirceu. O poema de Gonzaga teve um destino que contrasta vivamente com seus pressupostos de composição. Cunhada com os traços mais vivos e representativos da mentalidade dos setecentos, formalizada de acordo com preceitos de construção poética de seu tempo e em diálogo constante com as obras que a precederam e as de seus contemporâneos, foi com a sensibilidade romântica - esteticamente diversa e historicamente posterior - que a obra Marília de Dirceu foi avaliada, lida e valorizada. Os ecos dessa primeira leitura impregnaram de forma profunda sua fortuna crítica.

A sensibilidade romântica entendeu a poesia de Gonzaga como "sincera", "autêntica" e "sentimental". A arte foi entendida como expressão de subjetividade, e vida e obra se confundiram. Até hoje, os poemas de Gonzaga são apresentados como "ternos versos de amor do poeta que antecipou o Romantismo". O epíteto de pré-romântico serviu de elogio a Gonzaga, entre críticos brasileiros e portugueses, e seu mérito de precursor foi enaltecido à exaustão. Certas passagens da obra foram escolhidas e tomadas como antecipatórias do Romantismo. A "autenticidade" da emoção e o adensamento do Eu estariam presentes em versos como "Eu tenho um coração maior que o mundo/ tu, formosa Marília, bem o sabes (Lira II, 2)”. Em acréscimo a essas qualidades, o registro da paisagem local e de cenas de mineração, presentes ocasionalmente nas liras do poeta, serviu como prova de seu nacionalismo e brasilidade.

Pelas mesmas razões por que sua obra foi enaltecida, foi duramente criticada. Todos os aspectos que não se enquadravam na cartilha subjetivista e nacionalista, ou seja, todos os traços que não correspondiam a essas expectativas, foram considerados defeitos, como o "cálculo na elaboração" e a presença do "ferro-velho do maravilhoso pagão". 44

\footnotetext{
${ }^{44}$ FRIEIRO, Eduardo. O diabo na livraria do cônego; Como era Gonzaga? e outros temas mineiros. São Paulo: Edusp, 1981, p. 92
} 
Camilo Castelo Branco chegou a chamar as liras de Gonzaga de "um ramalhete seco de frivolidades". 45

A apreciação de Gonzaga feita pelo historiador francês Ferdinand Denis, em 1826, é exemplar: "Les poésies de Gonzaga se distinguent surtout par la naïveté, par la grâce de l'expression, par le charme attaché aux plaintes sincères d'un coeur aimant" ${ }^{\text {"46 }}$ [Distinguemse as poesias de Gonzaga, antes de tudo, pela ingenuidade, pela graça de expressão, pelo encanto inerente aos queixumes sinceros do coração enamorado"] ${ }^{47}$. Depois de elogiar a obra, Denis faz as restrições que se tornariam praticamente consensuais em nossa história literária:

Il faut reprocher à Gonzaga l'emploi continuel d'images poises dans la mytologie, e de ces forms de poésie pastoral répandues par Fontenelle: tout cela ne convenait guère à un poete brèsilien habitant un des pays òu la natures étale le plus de splendeur et de majesté. ${ }^{48}$ [Deve-se exprobar em Gonzaga o reiterado emprego de metáforas sugeridas pela mitologia, e de formas da poesia pastoral difundidas por Fontenelle: tudo isso pouco convém ao poeta brasileiro, habitante de regiões onde a natureza mais ostenta esplendor e majestade. $]^{49}$

Em Portugal, o crítico e romancista Almeida Garret dirigiu ao poeta censura semelhante no espírito, porém bem mais enfática na letra:

Quisera eu que em vez de nos debuxar no Brasil cenas da Arcádia, quadros inteiramente europeus, pintasse os seu painéis com as cores do país onde os situou. Oh e quanto não perdeu a poesia nesse fatal erro! Se essa amável, se essa ingênua Marília fosse, como a Virgínia de SaintPierre, sentar-se à sombra das palmeiras, e enquanto lhe revoavam em torno o cardeal soberbo com a púrpura dos reis, o sabiá terno e melodioso, - que saltasse pelos montes espressos a cotia fugaz como a lebre da Europa, ou grave passeasse pela oral da ribeira o tatu escamoso - ela se entretivesse a tecer para seu amigo e seu cantor uma grinalda não de rosas, não de jasmins, porém dos roxos martírios, das alvas flores dos vermelhos bagos do lustroso cafezeiro; que pintura, se a desenhara com sua natural graça o ingênuo pincel de Gonzaga. ${ }^{50}$

\footnotetext{
${ }^{45}$ BRANCO. Camilo C. Curso de literatura portuguesa. Lisboa: Livraria Editora de Mattos Moreira \& Cia., 1876, p. 250.

${ }^{46}$ DENIS, Ferdinand. Résumé de l'histoire littéraire du Brèsil. Paris, 1826, ch. V, p. 568. Apud NORBERTO, Joaquim. Marília de Dirceu. Liras de Tomás Antônio Gonzaga, precedidas de uma notícia biográfica e do juízo crítico de autores estrangeiros e nacionais, e das liras escritas em resposta às suas e acompanhadas de documentos históricos. Rio de Janeiro, Garnier, 1862, v. I, p. 21.

${ }^{47}$ Trad. Guilhermino César, in Ivan Teixeira, Revista USP, n. 57, 2003, p. 147.

${ }^{48}$ DENIS, op. cit., p. 21

${ }^{49}$ Trad. Guilhermino César, in Ivan Teixeira, Revista USP, n. 57, 2003, p. 147.

${ }^{50}$ GARRET, Almeida. Bosquejo da história da poesia e língua portuguesa. Parnaso Lusitano. Paris, 1826. T. I. p. 46. Apud SILVA, op. cit, p. 22.
} 
Diversos críticos apontaram a qualidade dos versos de Gonzaga e sua relevância para a literatura brasileira. "Em nossa literatura, Gonzaga é dos maiores poetas, dentre os sete ou oito que trouxeram alguma coisa à nossa visão do mundo", assegurou Antônio Candido. ${ }^{51}$ José Veríssimo referiu-se à Marília de Dirceu como "a mais nobre e perfeita idealização do amor da nossa poesia". 52 Machado de Assis definiu Gonzaga como "nosso maior lírico", e apontou nele "a graça, a sensibilidade, a perfeição do estilo". ${ }^{53}$

Segundo Alexandre Eulálio, foi alto o preço pago pelo prestígio conquistado pelo poeta, pois "conseguiu confundir, de modo quase inextricável, Lenda, Crônica, Biografia, Mito, Patriotada, Sentimentalismo, Verdade" ${ }^{54}$. O empenho para delinear uma biografia confiável de Tomás Antônio Gonzaga, para equacionar a questão de atribuição de autoria das liras e para estabelecer uma edição crítica de Marília de Dirceu consumiu também o esforço de muitos estudiosos, e o resultado desse trabalho só se efetivou em meados do século XX. Pesquisadores mais eruditos e especialistas comentaram o texto de Marília de Dirceu sobretudo nos prefácios e introduções às diferentes edições da obra, nas antologias e nas histórias literárias.

Diferentes trabalhos críticos, monografias, dissertações e teses continuaram sendo elaboradas por pesquisadores interessados em "deslindar" o sentido das liras de Marília de Dirceu. Infelizmente, o resultado de algumas dessas pesquisas pouco acrescentou ao legado crítico do poeta.

Apenas recentemente, trabalhos acadêmicos, sob a forma de artigos em revistas científicas, monografias, dissertações de mestrado e teses de doutorado começaram a investigar a obra de Gonzaga sob diferentes perspectivas, o que indica a renovação do interesse crítico pelo cantor de Marília. A partir da segunda metade do século XX, pesquisas de historiadores e especialistas em literatura vem permitindo uma visão mais abrangente e menos estereotipada da obra de Tomás Antônio Gonzaga. Em 1949, o estudo Tomás Antônio Gonzaga e o direito natural, de Lourival Gomes Machado, analisou os referenciais filosóficos e os argumentos teológicos do absolutismo utilizados por Gonzaga no Tratado do direito natural, redigido em Portugal. A pesquisa histórica de Keneth Maxwell, A devassa da devassa, publicada pela primeira vez em 1973, trouxe uma visão renovada sobre as relações econômicas e políticas entre Portugal e Brasil, que culminaram

\footnotetext{
${ }^{51}$ CANDIDO, Antônio. Formação da literatura brasileira, 1977, p. 121.

${ }^{52}$ VERÍSSIMO. J. Estudos de literatura brasileira. São Paulo: Edusp, 1977. $2^{\text {a }}$ série, p. 119.

${ }^{53}$ MACHADO DE ASSIS. A nova geração. In: Obras completas, p. 815.

${ }^{54}$ EULÁLIO, Alexandre. Verso e reverso de Gonzaga. In: Os melhores poemas de Tomás Antônio Gonzaga. São Paulo: Global, 1983, p. 11.
} 
com a Inconfidência Mineira, lançando nova luz sobre o papel dos poetas que nela estiveram envolvidos.

O estabelecimento do texto do poema épico À Conceição, atribuído a Gonzaga em seu período moçambicano, recebeu uma cuidada edição de Ronald Polito de Oliveira em 1995, o que abriu também novas possibilidades de compreensão para a obra do poeta. Além disso, Polito sumarizou as minuciosas pesquisas comparativas sobre a linguagem e a poética de Gonzaga empreendidas por Rodrigues Lapa, Manuel Bandeira e Afonso Pena Júnior, o que resultou em fonte importante para o estudo do texto de Marília de Dirceu.

O abrangente estudo de Joaci Furtado, Uma república de leitores, publicado em 1997, em que o autor faz um retrospecto histórico sobre a recepção crítica das Cartas chilenas, também representou uma valiosa contribuição para os estudos gonzaguianos. $\mathrm{O}$ trabalho Um coração maior que o mundo: Tomás Antônio Gonzaga e o horizonte lusocolonial, de 2004, também de Ronald Polito, empreendeu uma análise de conjunto dos textos de Gonzaga, buscando precisar uma relação entre eles, e extrair ideias e formas veiculadas nos textos. $\mathrm{O}$ autor discute concepções teológicas, políticas e sociais presentes nas obras Tratado de direito natural, Cartas chilenas e Marília de Dirceu.

Aos poucos, estudos críticos começam a deslindar uma imagem mais completa e complexa do poeta Tomás Antônio Gonzaga, como um poeta luso-brasileiro-moçambicano que se expressou em gêneros diversos, nas poesias lírica, épica e satírica. Para muitos estudiosos, entretanto, a viga mestra para a compreensão das liras de Gonzaga continua sendo o pressuposto biográfico - noivado desfeito e prisão injusta -, que fez coincidir vida e obra. A "emoção sincera e autêntica" parece ser ainda condição sine qua non para a análise crítica e a interpretação de Marília de Dirceu.

\subsection{Uma abordagem retórico-poética de Marília de Dirceu}

O caminho para o estudo da poética de Tomás Antônio Gonzaga e da figura de Marília de Dirceu ganhou novas possibilidades analíticas e interpretativas com a gradativa consolidação dos estudos poéticos e retóricos ocorrida no Brasil a partir de meados dos anos 1980. A compreensão da poesia de Gonzaga, bem como de seus contemporâneos ditos "árcades", ganhou renovado fôlego sob uma perspectiva histórica, que estuda as diferentes práticas discursivos do ponto de vista das preceptivas e convenções vigentes na América portuguesa dos séculos XVI, XVII e XVIII, partilhados por autores e público. 
O conhecimento de retóricas e preceptivas, antigas ou contemporâneas de Gonzaga, a compreensão de sua formação jesuítica, sob o Absolutismo Monárquico, e das consequências desses aspectos na sua forma de composição literária renovam o campo de atuação da crítica gonzaguiana e permitem compreender de que modo "encontra a realidade de seu tempo (...), como sistema de verossimilhanças e decoros partilhados por autores e públicos". 55

Conforme explicita Furtado, uma restituição do texto às práticas discursivas de sua época possibilitaria seu estudo como um artefato retórico:

se admitirmos que, antes do século XIX, a constituição de qualquer discurso compreendia um complexo sistema de normas, recursos, referências e modos de organização das ideias adequados a determinados fins, certamente as liras de Marília de Dirceu nos soariam menos familiares (...). É exatamente essa restituição arqueológica do texto às práticas discursivas de seu tempo que nos permitiria perceber, enfim, que o poema atribuído a Gonzaga é um artefato retórico. Nisto a fortuna foi mais generosa conosco do que com os arqueólogos que perscrutam cacos, não só porque há uma quantidade razoável de poemas semelhantes a Marília de Dirceu e contemporâneos dele, mas principalmente porque as preceptivas que orientavam sua confecção também nos são acessíveis. ${ }^{56}$

\footnotetext{
${ }^{55}$ HANSEN, João Adolfo. As liras de Gonzaga entre retórica e valor de troca. Revista Via Atlântica, n. 1, mar. 1997, p. 42.

${ }^{51}$ FURTADO, Joaci P. A sorte deste mundo: percursos de Marília de Dirceu no século XIX. Literatura: teoria e prática, v. 36, n. 72., 2018.
} 
2. CAPÍTULO 2 - Uma lira exemplar 


\section{1. Figura e fundo}

A figura de Marília não se desenha contra o fundo da poética de Tomás Antônio Gonzaga, mas com esta coincide plenamente. A composição retórico-poética que é Marília de Dirceu obedece a um regramento genérico, que será discutido no próximo capítulo. De qualquer modo, a presença de Marília é matéria fundamental do poema, que modula todas as sua liras, e não apenas um dos elementos dessa poética. A análise da lira I,1 que abre a primeira edição e todas as edições subsequentes de Marília de Dirceu ${ }^{57}$ é exemplar.

$\mathrm{Eu}$, Marília, não sou algum vaqueiro, Que viva de guardar alheio gado, De tosco trato, de expressões grosseiro, Dos frios gelos e dos sóis queimado. Tenho próprio casal e nele assisto;

Dá-me vinho, legume, fruta, azeite; Das brancas ovelhinhas tiro o leite, $\mathrm{E}$ mais as finas lãs, de que me visto. Graças, Marília bela, Graças à minha Estrela!

Eu vi o meu semblante numa fonte:

Dos anos inda não está cortado;

Os Pastores, que habitam este monte,

Respeitam o poder do meu cajado.

Com tal destreza toco a sanfoninha,

Que inveja até me tem o próprio Alceste:

Ao som dela concerto a voz celeste

Nem canto letra que não seja minha.

Graças, Marília bela,

Graças à minha Estrela!

Mas tendo tantos dotes da ventura,

Só apreço lhes dou, gentil Pastora,

Depois que o teu afeto me segura

Que queres do que tenho ser Senhora.

É bom, minha Marília, é bom ser dono

De um rebanho, que cubra monte e prado;

Porém, gentil Pastora, ${ }^{58}$ o teu agrado

\footnotetext{
57 Exceto a edição de Rodrigues Lapa, de 1957, que reordenou e numerou as liras em suposta ordem cronológica.

${ }^{58}$ Para o estudo da lira I,1, cotejamos a edição Aguilar com a edição princeps (fac-símile de: Lisboa: na Typografia Nunesiana, 1792, publicada como Marília de Dirceo por T.A.G. Rio de Janeiro, Fundação Biblioteca Nacional, Dep. Nacional do Livro, 1995). Nas variações encontradas no uso de maiúsculas, optamos pela forma encontrada na edição princeps. Na edição Aguilar, pastora, na edição princeps, Pastora.
} 
Vale mais que um rebanho, e mais que um trono.

Graças, Marília bela,

Graças à minha Estrela!

Os teus olhos espalham luz divina,

A quem a luz do $\mathrm{Sol}^{59} \mathrm{em}$ vão se atreve;

Papoila ou rosa delicada e fina

Te cobre as faces, que são cor da neve.

Os teus cabelos são uns fios d'ouro;

Teu lindo corpo bálsamos vapora.

$\mathrm{Ah}$ ! não, não fez o Céu, gentil Pastora,

Para glória ${ }^{60}$ de Amor ${ }^{61}$ igual Tesouro.

Graças, Marília bela,

Graças à minha Estrela!

Leve-me a sementeira muito embora

O rio, sobre os campos levantado;

Acabe, acabe a peste matadora,

Sem deixar uma rês, o nédio gado.

Já destes bens, Marília, não preciso

Nem me cega a paixão, que o mundo arrasta;

Para viver feliz, Marília, basta

Que os olhos movas, e me dês um riso.

Graças, Marília bela,

Graças à minha Estrela!

Irás a divertir-te na floresta,

Sustentada, Marília, no meu braço;

Aqui descansarei a quente sesta,

Dormindo um leve sono em teu regaço;

Enquanto a luta jogam os Pastores,

E emparelhados correm nas campinas,

Toucarei teus cabelos de boninas,

Nos troncos gravarei os teus louvores.

Graças, Marília bela,

Graças à minha Estrela!

Depois que nos ferir a mão da Morte,

Ou seja neste monte, ou noutra serra,

Nossos corpos terão, terão a sorte

De consumir os dous a mesma terra.

Na campa, rodeada de ciprestes,

Lerão estas palavras os Pastores:

"Quem quiser ser feliz nos seus amores,

Siga os exemplos, que nos deram estes".

Graças, Marília bela,

Graças à minha Estrela!

A lira I, 1, que passamos a analisar, tem uma estrutura estrófica, assim como todas as demais de Marília de Dirceu. A estrofe é desenhada com um determinado número de

\footnotetext{
${ }^{59} \mathrm{Na}$ edição Aguilar, sol, na edição princeps, Sol.

${ }^{60} \mathrm{Na}$ edição Aguilar, Glória, na edição princeps, glória.

${ }^{61} \mathrm{Na}$ edição Aguilar, amor, na edição princeps, Amor.
} 
versos, segue um padrão métrico e um esquema de rimas, apresentando no geral também um estribilho. A lira gonzaguiana é formada por um número preestabelecido de estrofes que se repetem com a mesma estrutura rítmica. Dessa forma, nenhuma lira é igual à outra.

A lira I, 1 é formada por sete estrofes. Tomás Antônio Gonzaga é um poeta reconhecido por sua habilidade na versificação, pela musicalidade, pela destreza e graça com que maneja a expressão e pelo efeito de simplicidade que provoca no leitor. Uma análise da primeira estrofe da lira I, 1, do ponto de vista rítmico, métrico, do uso das rimas internas e dos demais recursos sonoros, nos fornece uma pequena amostra do virtuosismo do poeta. A lira I, 1 é composta inteiramente de decassílabos graves. A cadência padrão é o decassílabo heroico (com acentos na sexta e décima sílabas: 6/10). Este padrão de decassílabos heroicos é mesclado com o emprego de decassílabos sáficos (que têm acentos na quarta, oitava e décima sílabas), em menor quantidade. Vejamos:

$\begin{array}{lr}\text { Eu, Marília, não sou algum vaqueiro, } & 6 / 10 \\ \text { Que viva de guardar alheio gado; } & 6 / 10 \\ \text { De tosco trato, de expressões grosseiro, } & 4 / 8 / 10 \\ \text { Dos frios gelos e dos sóis queimado. } & 4 / 8 / 10 \\ \text { Tenho próprio casal e nele assisto; } & 6 / 10 \\ \text { Dá-me vinho, legume, fruta, azeite; } & 6 / 10 \\ \text { Das brancas ovelhinhas tiro o leite, } & 6 / 10 \\ \text { E mais as finas lãs de que me visto. } & 6 / 10\end{array}$

A mescla entre versos heroicos e sáficos, que se reproduz nas outras estrofes desta mesma lira (apenas arranjada de modo diferenciado), não é suficiente para elucidar o intenso colorido rítmico da poética de Gonzaga. Uma análise mais minuciosa desta primeira estrofe mostra como o poeta não se vale de um padrão rítmico uniforme, mas cria cadências variadas e inesperadas, utilizando-se dos acentos secundários em seus versos. Embora possa ser lido como um decassílabo heroico, temos de reconhecer um rimo mais lento no primeiro verso, causado por acentos secundários na primeira e terceira sílabas:

$E u$, Marília, não sou algum vaqueiro,

Outros versos, embora em termos gerais possam ser considerados heroicos, apresentam acentos diferentes, proporcionados pelo relevo semântico, pela sintaxe diferenciada, pela pontuação enfática. O segundo verso, por exemplo, apresenta uma insistência na segunda sílaba. 
Que viva de guardar alheio gado;

O quinto verso, também um decassílabo heroico, tem, por sua vez, acentuação secundária na terceira sílaba.

Tenho próprio casal e nele assisto;

O mesmo pode ser sentido no verso seguinte.

Dá-me vinho, legume, fruta, azeite;

Podemos ressaltar nesse caso, entretanto, que os termos, por estarem isolados entre vírgulas, fazem saltar todas as sílabas tônicas.

Dá-me vinho, legume, fruta, azeite;

Os dois últimos versos também são heroicos, entretanto, têm acentuação secundária na segunda sílaba.

Das brancas ovelhinhas tiro o leite,

E mais as finas lãs, de que me visto.

Essa isomorfia rítmica emparelha os dois versos, realçando a aproximação semântica entre eles, baseada no par leite/lã.

Entre os versos sáficos, observamos o mesmo procedimento poético com relação aos acentos secundários. O terceiro e o quarto versos são idênticos do ponto de vista rítmico, o que reproduz uma similaridade semântica também. Ambos têm acento secundário na segunda sílaba.

De tosco trato, de expressões grosseiro,

Dos frios gelos e dos sóis queimado.

A estrofe divide-se naturalmente em duas partes de quatro versos; isto se deve ao esquema de rimas, cruzadas nos primeiros quatro versos ( $a b a b)$ e entrelaçadas nos quatro últimos versos $(c d d c)$. No estribilho, as rimas são emparelhadas (ee).

Eu, Marília, não sou algum vaqueiro, a

Que viva de guardar alheio gado; $\quad \mathrm{b}$ 
De tosco trato, de expressões grosseiro a

Dos frios gelos e dos sóis queimado. $\quad \mathrm{b}$

Tenho próprio casal e nele assisto; $\quad \mathrm{c}$

Dá-me vinho, legume, fruta, azeite; d

Das brancas ovelhinhas tiro o leite, $\quad d$

E mais as finas lãs, de que me visto. $\quad$ c

Graças, Marília bela, e

Graças à minha Estrela! $\quad \mathrm{e}$

Notam-se na primeira quadra as repetições de certos fonemas consonantais, como a fricativa linguodental /v/ (vaqueiro, viva), a oclusiva linguodental /t/ (tosco, trato) e as oclusivas linguopalatais /q/ (vaqueiro, que, queimado) e /g/ (algum, guardar gado, grosseiro). Também são utilizadas sílabas formadas pelo /r/ intercalado: trato, expressões, grosseiro, frio, que remetem à rusticidade no plano semântico que permeia todo o período. A presença de rimas internas toantes, como vaqueiro/alheio e gado/trato garantem uma notável coesão sonora.

$\mathrm{Na}$ segunda quadra desta estrofe, predominam as consoantes líquidas e nasais. São exemplos do primeiro tipo o /1/ [casal, legume, leite, lã] e o /lh/ [ovelhinha]. As consoantes nasais são o /nh/ [vinho, ovelhinhas], que se complementam com as vogais nasais [brancas, lãs]. Há uma presença abundante de vogais de timbre fechado, como o /ê/ (nele, azeite, leite) e /i/, assisto, vinho, tiro, ovelhinha, /u/legume fruta. O poeta não abandona os vocábulos que contêm sílabas com $/ \mathrm{r} /$ intercalado, retomando o procedimento dos primeiros versos: próprio, fruta, branca. As rimas toantes internas também são empregadas: legume/fruta, vinho/ovelhinhas/finas.

O poema abre-se com a preeminência de uma persona poética.

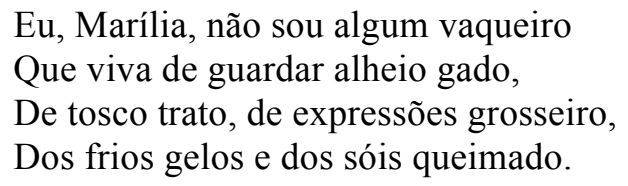

A este enunciador, colocado em primeiro plano, será emparelhado o nome de Marília, sob a forma de um vocativo. Marília, a quem o enunciador se dirige, é a destinatária do enunciado. O leitor imagina, pois, uma situação de interlocução com dois participantes. Este colocar lado a lado o eu e o nome de Marília remete ao título da obra, Marília de Dirceu, em que o "eu" incrusta-se no nome do pastor e a palavra lira encaixa-se anagramaticamente no nome de Marília (veja-se a trinca esta/floresta/festa na lira I-7 ou o par divino/dino na lira I-33, procedimentos análogos ao que se quer demonstrar). 
Segue-se a descrição da persona poética. A abertura sugere explicitude no uso da ordem direta e na simplicidade dos vocábulos adotados; no entanto a argumentação utiliza uma litotes: o pastor define-se pelo negativo. ${ }^{62}$ De que caracterização afasta-se o eu poético? Do pastor de baixa extração social (guardador de gado alheio), não cultivado (de tosco trato, grosseiro de expressões) e de aparência rústica, envelhecido (queimado dos frios gelos e dos sóis). Posição social, refinamento no trato e boa aparência/jovialidade são, nesta ordem e por contraste, sugeridos. Esta caracterização pelo negativo cria como pano de fundo a figura do rústico pastor vivendo em seu próprio ambiente, o que ao mesmo tempo introduz o universo da alegoria pastoril e valoriza os dotes com que o poeta se apresenta. Os versos seguintes afirmam, em paralelismo, o que foi apenas sugerido nos primeiros versos:

Tenho próprio casal e nele assisto;

Dá me vinho, legume, fruta, azeite;

Das brancas ovelhinhas tiro o leite,

E mais as finas lãs de que me visto.

O pastor revela, em primeiro lugar, sua condição de proprietário, enumerando assindeticamente os bens de que esta propriedade o provê. Em seguida, refere-se ao gado que possui. A expressão "brancas ovelhinhas" contém ressonâncias afetivas no diminutivo

\footnotetext{
nas artes divinatórias, músico e inventor da medicina.

Pergunte a quem te apraz; eu não habito em montes, não sou pastor, não sou um rude guardador de rebanhos e reses. Não sabes de quem foges, por isso, insana, foges. Sou senhor de Delfos e de Claros, de Tenedo e Pátara. Júpiter é meu pai; o futuro, o passado e o presente desvelo. Ajusto o verso às cordas. Certeira é minha flecha, mas uma mais certa encheu meu peito ainda vago de feridas. Medicina inventei, chamam-me salutar em todo o orbe e tenho poder sobre as ervas. Ai de mim, o amor não se cura com as ervas, e estas artes a todos úteis não me valem".
}

${ }^{62}$ A descrição pelo negativo está presente nas Metamorfoses, do poeta latino Ovídio, como observou João Angelo Oliva Neto (Informação verbal, 29/03/2019)). Após ter vencido a serpente Píton, Apolo, que anteriormente se dedicava ao pastoreio, jacta-se perante Cupido e, com soberba, afirma sua superioridade. Cupido, tomado de ira, lança duas flechas, a primeiro com um dardo dourado que atrai amor e a outra com um dardo de chumbo, que o afugenta, fazendo com que Febo persiga a ninfa Dafne e que esta sempre lhe fuja. No poema latino, Apolo se descreve deste modo para sua amada, primeiramente afirmando aquilo que não é, um rústico guardador de gado, para depois valorizar ainda mais suas qualidades de semideus, mestre

OVÍDIO, Metamorfoses, Livro I, vv. 512-524. Trad. Raimundo Nonato de Carvalho. In: CARVALHO, Raimundo N. de. Relatório apresentado ao Programa de Pós-Graduação em Letras Clássicas e Vernáculas da FFLC da USP. Supervisão: Prof. Dr. João Angelo Oliva Neto. São Paulo, 2010. Metamorfoses em tradução. p. 54. 
e plásticas no diminutivo. As ovelhas garantem a um só tempo sustento e elegância: vestirse de finas lãs é marca de elevada condição social. A estrofe transmite serenidade e contenção nas orações curtas, declarativas, que se sobrepõem placidamente.

O estribilho remata esta introdução, construindo a graciosidade e a leveza do poema com seus versos de seis sílabas (heroico quebrado).

Graças, Marília bela, Graças à minha Estrela.

O nome de Marília, agora já acrescido de seu epíteto (Marília bela), une-se à sorte e ao destino da persona poética. Novamente aqui a intercalação do vocativo retarda e valoriza a informação, que é ainda enfatizada pelo emprego da forma exclamativa. A repetição do estribilho ao final de cada estrofe, bem como a recorrência ao nome de Marília servem também para dar unidade aos muitos afetos figurados no poema. Apesar de as estrofes serem formalmente homogêneas do ponto de vista rítmico, métrico e estrófico, são muito variadas entre si na expressão, construindo o movimento da totalidade da lira.

A segunda estrofe parece estender a autodescrição da persona poética.

Eu vi o meu semblante numa fonte,

Dos anos inda não está cortado;

Apesar de constituir um topos recorrente na tradição (Narciso que se observa nas águas), convém assinalar que a imagem no espelho confere certa objetividade à descrição, amplificando o efeito de realidade. A fonte também é um elemento que completa o cenário pastoral, assim como o aspecto jovial vem completar o éthos do poeta.

Aos poucos, certos elementos são trazidos à cena para criar perspectivas, referenciais e contrastes. Se na primeira estrofe o pastor grosseiro serviu para criar o negativo do poeta, um contraponto à sua figura, aqui o espelho duplica, reforça e testemunha sua boa aparência.

Nos versos seguintes, a afirmação do que foi dito obliquamente nos primeiros versos estará completa: a respeitabilidade de Dirceu é aqui alcançada e reforçada pela presença de outros pastores, por meio dos quais é possível ver as marcas de distinção do poeta:

Os Pastores, que habitam este monte, Respeitam o poder do meu cajado. 
A presença dos outros pastores será suplantada, a seguir, pela presença de Alceste:

Com tal destreza toco a sanfoninha,

Que inveja até me tem o próprio Alceste:

ao som dela concerto a voz celeste,

nem canto letra que não seja minha.

O nome de Alceste adentra a cena sem nenhuma apresentação, sem nenhuma adjetivação, o que coloca o leitor em intimidade com o jogo da alegoria pastoril. A proximidade que a presença do interlocutor sugeria é aqui reforçada. Alceste funciona também como duplo e rival que, ao invejar o talento do poeta, o enaltece. É ativado aqui o cenário relativo ao topos do pastor/poeta em disputa com outro pastor, presente na tradição bucólica e consagrado nas éclogas dramáticas de Virgílio.

Se a escassez de verbos ("sou" e "tenho") e a coordenação das orações na primeira estrofe nos dão um perfil de certa forma estático e frio do poeta, aqui a presença de seus pares, aliada à expansão das orações subordinadas e dos verbos que indicam continuidade e duração, coloca este perfil em movimento. $\mathrm{O}$ eu poético é posto em ação em seu ambiente campestre ("olhar a fonte", "tocar a sanfoninha"), e em correlação com seus companheiros ("ser respeitado pelos pastores, invejado por Alceste"). Um novo elemento vem-se incorporar ao ethos do poeta: seus dotes artísticos. Estes serão apresentados num crescendo que vai desde a habilidade em tocar o instrumento, passa pelo talento em cantar letra própria e chega às alturas ao concertar a voz celeste.

Esta elevação progressiva prepara o leitor para a entrada em cena de Marília, na terceira estrofe:

\footnotetext{
Mas tendo tantos dotes da ventura, Só apreço lhes dou, gentil Pastora, Depois que o teu afeto me segura Que queres do que tenho ser Senhora.
}

A interlocutora, que até então se mantinha externa à cena, adentra a cena, participando, com seu reclamado afeto, da argumentação. A simplicidade sintática é agora substituída por um fraseado argumentativo, em que o eu poético se projeta.

Os dotes da ventura (a propriedade, a lavoura, o gado, a boa aparência e a honradez, agora acrescidos do talento artístico) serão aproximados de Marília, e o clima harmônico das primeiras estrofes projeta-se para o futuro desejado. A expressão "depois que o teu afeto me segura" sugere ao mesmo tempo desejo e possibilidade, projetando para 
o futuro, para um terreno idílico, a harmonia total: o afeto de Marília cobrindo toda a extensão das características do pastor, das suas cercanias.

As marcas da fatura árcade (a vida rural, a sanfoninha, a presença dos pastores) são finalmente enfeixados em Marília. Apenas neste momento Marília passa a ter uma relação de proximidade com o poeta, passa de interlocutora contemplativa à presença invocada. Há um procedimento gradativo de aproximações em que o vocativo passa de "Marília" à "Marília bela" até se transformar em "gentil pastora". Marília passa a ser dona do poeta e de seus bens. Destinatária e persona poética agora harmonizam-se, ambos ocupando o espaço poético: pastor e pastora formam um par e o afeto da gentil pastora corresponde ao perfil do pastor que se exibe e se declara. Os versos seguintes matizam o que já foi enunciado:

É bom, minha Marília, é bom ser dono

De um rebanho, que cubra monte e prado;

Porém, gentil Pastora, o teu agrado

Vale mais que um rebanho, e mais que um trono.

Graças, Marília bela,

Graças à minha Estrela!

A oração principal do período é retardada pela intercalação do vocativo: neste período, "minha Marília" e "gentil Pastora" equivalem-se. A repetição do termo "bom” dá ênfase à exclamação velada, e a prosperidade desejada das relações amorosas tem seu equivalente no rebanho, que aqui já se espraia por monte e prado. Nos dois últimos versos, porém, a presença de Marília (que até então se harmonizava à do pastor) sobrepõe-se aos dotes do pastor: ela se eleva acima deles. O agrado de Marília vale mais que um rebanho, é hiperbolizado, vale ainda mais que um trono. ${ }^{63}$ A sublimidade de Marília vai sendo construída.

Os teus olhos espalham luz divina,

A quem a luz do sol em vão se atreve;

Papoila ou rosa delicada e fina

Te cobre as faces, que são cor de neve.

\footnotetext{
${ }^{63}$ João Adolfo Hansen observa como, nesse sentido, a persona poética aquilata Marília junto a seus pertences, colocando-a em um dos pratos da balança. (Comunicação oral, 18/12/2020)
} 
Os teus cabelos são uns fios d'ouro;

Teu lindo corpo bálsamos vapora.

Nesta quarta estrofe, que ocupa um lugar central na lira, e pode ser considerada uma transição entre a primeira e a segunda partes da lira, o poeta põe-se a pintar Marília, a descrever sua aparência. Aparentemente, devido ao emprego da segunda pessoa do discurso, a voz é emprestada à interlocutora. Marília, no entanto, não é o sujeito do enunciado. No lugar de um possível tu, o sujeito das orações transforma-se em "teus olhos", "teus cabelos", "teu lindo corpo". Marília é descrita metonimicamente. De personagem a habitar a cena pastoril em condições de igualdade com o poeta-pastor, Marília aparece agora com o perfil estático da efígie. Marília será pintada como um retrato, numa sensualidade contemplativa, composta de luzes, cores e aromas.

O pintor obedece a um ordenamento na pintura do retrato da amada: inicia com a descrição dos olhos; a seguir, pinta as faces em termos de textura e cor, para depois emoldurá-las com os cabelos. Só então fará surgir o retrato de corpo inteiro. O branco, o rosa e o dourado serão sobrepostos à luminosidade absoluta de seu olhar. O conjunto é completado com os bálsamos vaporosos.

Os termos da comparação são tomados, simultaneamente, da natureza e da convenção poética. Sol, flores, neve e ouro são metáforas simples, que possuem poder de concretude muito grande, mas ao mesmo tempo apontam para uma elevação. A descrição deste retrato convencional contrasta vivamente com a descrição que o poeta fizera de si mesmo nas estrofes anteriores. A figura do proprietário, que alimenta-se de fruta, legumes, vinho e azeite e veste finas lãs, travestido de pastor que toca sanfoninha tão bem que causa inveja a seus companheiros, contrasta com essa figura idealizada de Marília. ${ }^{64}$

O prosaísmo com que o eu poético se descreve difere muito da elevação e da distância com que a figura de Marília é pintada: como um retrato poético, um tesouro criado por seu autor para a glória do amor. O cantor que "concerta a voz celeste" pinta agora com sua pena a figura de Marília, muito distante aqui daquela gentil pastora que poderia ser sua senhora. ${ }^{65}$

\footnotetext{
${ }^{64}$ João Adolfo Hansen comenta como a condição de proprietário é explicitada por Gonzaga, o que seria um traço novo de sua poesia, regrada nas convenções poéticas. Tratar de temas pecuniários cabia, em sua época, a personagens da comédia, ou seja, personagens vulgares. Gonzaga ousa ainda, nesta lira, ao colocar em um dos pratos da balança o valor de Marília e no outro seus bens. (Informação verbal em arguição, 18/12/2020)

${ }^{65}$ Pereira da Silva compara essa descrição de Marília à descrição de Laura por Petrarca: "O fiamma, o rose sparse in dolce falda/ Di viva neve, in ch'io mi specchio e tergo/ O piacer, onde l' ali al bel viso ergo/ Che luce sovra quanti il sol ne scalda". In: SILVA, J. M. Pereira da, Introdução à Marília de Dirceu. Rio de Janeiro: Laemmert, 1845. p. XXIII.
} 
Os dois últimos versos parecem destacar-se da estrofe pelo modo exclamativo e pela mudança de dicção:

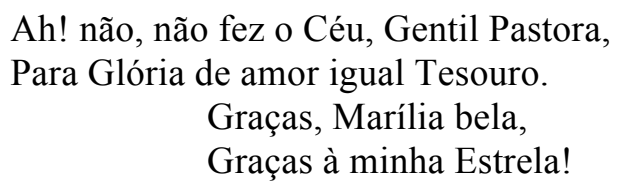

Se as três estrofes anteriores se mantinham em paralelismo sintático, divididas igualmente por dois períodos com a dimensão de quatro versos, nesta temos dois períodos que se ligam semanticamente na descrição de Marília e ocupam seis versos. Nos dois últimos versos, passa-se do afeto contido da descrição a uma exaltação emotiva. $\mathrm{O}$ advérbio é puxado para o início da oração e enfatizado pela repetição e em toda a frase há modulação e afetividade. Mas, em vez de essa afetividade voltar-se para a figura de Marília, ela reflui para a persona poética. Aquele mesmo que "concerta a voz celeste" parece agora contemplar o retrato que pintou de Marília. Chegamos ao clímax do poema. $\mathrm{O}$ movimento ascensional é aqui interrompido pelos dois versos que parecem competir com o estribilho.

A dicção elevada da descrição generalizante, criada pelo retrato de Marília e corroborada pela exaltação dos dois últimos versos, interrompe-se. O poeta volta a se referir à sua condição, à materialidade de seus bens:

Leve-me à sementeira muito embora

O rio, sobre os campos levantado;

Acabe, acabe a peste matadora,

Sem deixar uma rês, o nédio gado.

Novamente temos a estrutura argumentativa e, aqui, duas hipotéticas tragédias são apresentadas para consideração do leitor: a primeira (a inundação dos rios, que certamente acabará com a lavoura) é duplicada pela segunda (a peste que matará o gado). A destruição atinge o imaginário construído na primeira estrofe e será o coroamento de um processo em que os bens materiais serão paulatinamente solapados pela presença de Marília:

Já destes bens, Marília, não preciso

Nem me cega a paixão, que o mundo arrasta;

Para viver feliz, Marília, basta

Que os olhos movas, e me dês um riso.

Graças, Marília bela,

Graças à minha Estrela! 
O poeta desprende-se de seus afazeres e necessidades mundanas ("já destes bens, Marília, não preciso") e de sua humana condição ("nem me cega a paixão/que o mundo arrasta") ${ }^{66}$ para aproximar-se de Marília, cujo nome é duas vezes evocado. A figura estática anima-se de vida: ri e move os olhos. Podemos considerar aqui a figuração de uma Marília que se comporta como personagem: pela primeira vez no poema, embora ainda no campo hipotético, ela é o sujeito de ações concretas.

$\mathrm{Na}$ estrofe seguinte, o eu poético, então projetado para o terreno idílico, é novamente o pastor, agora totalmente desvinculado de suas singularidades. Marília cria vida e aproxima-se do pastor, cúmplice, plenamente à vontade em suas roupas de pastora.

Irás a divertir-te na floresta, Sustentada, Marília, no meu braço; Aqui descansarei a quente sesta, Dormindo um leve sono em teu regaço; Enquanto a luta jogam os pastores, E emparelhados correm nas campinas, Toucarei teu cabelo de boninas, Nos troncos gravarei os teus louvores. Graças, Marília bela, Graças à minha Estrela!

Neste ponto, a interlocutora é convidada a assistir ao espetáculo da felicidade futura junto do enunciador: aquela Marília que aparece no vocativo contempla-se a si mesma na cena pastoril, em que o eu poético se traveste de pastor enamorado. Os verbos no futuro hipotético criam uma duração indeterminada, sugerindo uma ação que se repete no tempo ou deslocando a ação para além do tempo. Transfigurada pela imaginação, Marília passeia pela floresta, empresta seu regaço para o sono do pastor, deixa-se toucar os cabelos de flores. Pela primeira vez, Marília atua como sujeito da ação ("irás a divertir-te na floresta"), protagonizando uma sucessão de cenas pastoris que representam a afetividade. Há uma certa itinerância. O leitor acompanha a sequência que vai do passeio de braços dados, passa pelo descanso na floresta e termina com a graciosa cena do toucado. Vale ressaltar o caráter imagético desse discurso, bem como a vividez e clareza com que a sequência é descrita visualmente.

A passagem realiza plenamente a rusticidade fingida que caracteriza o gênero bucólico. Com poucas tintas e muitos verbos de ação, o poeta cria uma sucessão de cenas

\footnotetext{
${ }^{66}$ Conforme lembra João Angelo Oliva Neto, pode-se mencionar aqui um repto do poeta latino Tibulo, na imagem da "cega paixão que o mundo arrasta" e das catástrofes que podem ocorrer enquanto o poeta se encontra no regaço da amada. (Informação oral, exame de qualificação, 29.03.2019.)
} 
pastoris em que pastor e pastora se movimentam e se tocam, finalizando o idílio com a ação, solitária, de gravar no tronco os louvores de Marília. Trata-se de uma inscrição poética que remata a estrofe e cristaliza novamente a ação, prenunciando o desfecho de toda a lira. A movimentação das personagens pastoris transforma-se novamente num discurso epidítico: cantar os louvores de Marília gravando-os no tronco.

A última estrofe avança ainda mais no tempo; ela se dá, hipoteticamente, num tempo mais longínquo do que o da estrofe anterior:

\title{
Depois que nos ferir a mão da Morte, Ou seja neste monte, ou noutra serra, Nossos corpos terão, terão a sorte De consumir os dous a mesma terra.
}

Unidos na eternidade, os pastores transformam-se em corpos a serem consumidos pela terra. Uma nova inscrição poética é gravada na lápide.

\author{
Na campa, rodeada de ciprestes, \\ Lerão estas palavras os Pastores: \\ "Quem quiser ser feliz nos seu amores \\ Siga o exemplo, que nos deram estes". \\ Graças, Marília bela, \\ Graças à minha Estrela!
}

Se na estrofe anterior o epigrama era apenas sugerido, agora suas palavras são reproduzidas para o leitor. A leitura da inscrição na campa compõe novamente uma cena pastoril, que enfeixa a anterior, descrita na sexta estrofe. Se na cena anterior se adivinhava a posteridade dos louvores de Marília no tronco onde o pastor os gravara, aqui ela se consuma na inscrição na lápide. As personagens, cuja concretude até há um minuto nos encantara, dissolvem-se e adquirem exemplaridade, tornando-se paradigma da felicidade no amor. Há uma recuperação do emparelhamento inicial do primeiro verso: eu e Marília, unidos para sempre pela fantasia do poeta, convertem-se em "estes". A resolução, inesperada, cristaliza todo o discurso do poema em dois versos. O movimento e as tensões vividas pelas relações entre o eu poético e Marília são convertidos em epigrama que os imobiliza no tempo. Outros pastores lerão os amores de Marília e Dirceu, na posteridade, sorrirão e seguirão caminho. Os dois últimos versos rematam as volutas vivenciadas pelo leitor no transcorrer do poema. Este converte-se também num pastor-leitor. O poema encerra-se placidamente. 


\section{2 - Aspectos da poética de Tomás Antônio Gonzaga}

Ando já com o juízo,

Marília, tão perturbado

que no mesmo aberto sulco

meto de novo o arado.

Certos procedimentos identificáveis na Lira I, 1 conferem unidade à poética de Tomás Antônio Gonzaga por estarem presentes em quase todas as suas liras. Passados mais de dois séculos de sua composição, as liras de Marília de Dirceu conservam, no plano lexical, poucos traços de época. A escolha vocabular sempre se faz em favor da simplicidade (em vez de "níveo", por exemplo, Gonzaga usará "branco" ou "cor da neve") e a preferência recai sempre sobre termos de uso corrente. ${ }^{67}$ São evidentes em Gonzaga os traços de simplificação, contenção de linguagem e recusa dos excessos, que regem de modo geral a produção poética do Arcadismo. Nota-se a conformidade com a lição de Luís António Verney (1746, p. 127) defendendo a simplicidade do discurso, contra os esquemas métricos, as adjetivações e afetações que vicejavam em Portugal. Ao defender a utilidade da retórica, Verney afirma que "o discurso de um homem despido de artifício não pode menos que ser um caos" (VERNEY, 1746, p. 126). ${ }^{68}$

A aparente simplicidade da expressão é reforçada pelo uso de poucos adjetivos (na Lira I,1 são sete para um total de quinze substantivos), pela preferência por substantivos concretos e por formas analíticas, como no primeiro verso da quarta estrofe de I,1 ("Os teus cabelos são uns fios d'ouro"). O emprego de substantivos concretos responde em grande parte pela evocação que a poesia de Gonzaga desperta no leitor. Tanto na composição do cenário pastoril (ao utilizar a tópica da poesia pastoral, como a sanfoninha, as ovelhinhas, o cajado, a fonte, o prado, o rio), como na pintura do retrato de Marília (ao mencionar a papoula, a rosa, a neve, o ouro), o poeta recorre a elementos de grande força pictórica.

\footnotetext{
${ }^{67}$ João Adolfo Hansen comenta o uso dos símiles em artigo: “A recusa do conceito engenhoso ou da agudeza conceptista, ou seja, a recusa da metáfora como base do conceito, é evidenciada na poesia árcade na preferência estatística pela comparação (...) que é explicitamente lógica: Marília é como (e não Marília é...). Esse procedimento poderia ser tomado como um índice geral dessa poesia, porque pode significar, como também já se viu, que ela já aparece como que descolada do pensamento neoescolástico e corporativista que fundamentava as agudezas no século XVII, em Portugal e no Brasil". HANSEN, João Adolfo. As liras de Gonzaga: entre retórica e valor de troca. Via Atlântica, n. 1, 1997, p. 48.

${ }^{68}$ VERNEY, L. A. Verdadeiro método de estudar. Valença [Nápoles]: Oficina de Antônio Balle, Tipografia Mutina, imp. 1746.
} 
O apelo à imaginação do leitor ocorre, entretanto, sobretudo na apresentação de cenas dinâmicas, em que a expressão direta se alia ao gosto pelo detalhe como nos versos "Irás a divertir-te na floresta, / Sustentada, Marília, no meu braço" (Lira I,1, vv. 51-52); “Toucarei teus cabelos de boninas" (Lira I,1, v. 57) ou "Na campa, rodeada de ciprestes,/ Lerão estas palavras os pastores" (Lira I,1, vv. 65-66). Note-se que na composição da cena pastoril o poeta apresenta ao leitor "o que acontece, como e onde" com grande concisão e precisão.

O despojamento de Gonzaga manifesta-se também no plano sintático. Apesar de empregar períodos longos, as pausas sintáticas geralmente coincidem com o final dos versos, dando fluência à leitura. $\mathrm{Na}$ Lira I,1, todas as pausas sintáticas estão colocadas no final dos versos. As estrofes apresentam o seguinte esquema sintático. 
Quadro 3 - Relação entre a extensão dos períodos gramaticais e a quantidade de versos na lira I,1.

\begin{tabular}{|c|c|}
\hline Estrofe 1 & 4 versos \\
\hline & 4 versos \\
\hline & 1 verso \\
\hline & 1 verso \\
\hline Estrofe 2 & 4 versos \\
\hline & 4 versos \\
\hline & 1 verso \\
\hline & 1 verso \\
\hline Estrofe 3 & 4 versos \\
\hline & 4 versos \\
\hline & 1 verso \\
\hline & 1 verso \\
\hline Estrofe 4 & 4 versos \\
\hline & 2 versos \\
\hline & 2 versos \\
\hline & 1 verso \\
\hline Estrofe 5 & 4 versos \\
\hline & 4 versos \\
\hline & 1 verso \\
\hline & 1 verso \\
\hline Estrofe 6 & 8 versos \\
\hline & 1 verso \\
\hline & 1 verso \\
\hline Estrofe 7 & 4 versos \\
\hline & 4 versos \\
\hline & 1 verso \\
\hline & 1 verso \\
\hline
\end{tabular}


Observamos que a disposição dos períodos nos versos obedece a um padrão, que é seguido nas estrofes $1,2,3,5$ e 7 . Nesses casos, o corpo do poema está dividido em dois períodos que ocupam quatro versos cada, seguido pelo estribilho, formado por duas orações distintas. Nas estrofes que não seguem este padrão, observamos uma clara motivação temática, a saber: na estrofe 3 , em que o poeta pinta o retrato de Marília, a divisão sintática do corpo do poema se faz em função da distribuição dos assuntos (um período ocupando quatro versos trata dos olhos e da cor da face de Marília; um segundo período ocupando dois versos trata dos cabelos e dos bálsamos que emanam do corpo da pastora e um último período ocupando dois versos enaltece os atributos de Marília como tesouro celeste). Na estrofe 6, um único período compreendendo oito versos no corpo do poema contém uma sequência de cenas pastoris.

Num estudo sobre Gonzaga, ao lembrar da poesia de Guarini, o estudioso João Adolfo Hansen elenca as características próprias dessa "poesia que se dá como efeito de falta de efeito, como simplicidade e naturalidade". ${ }^{69}$

\begin{abstract}
Retoricamente equidistante dos extremos do plebeísmo e do hermetismo, deve aparecer para o leitor como elegante, terna, clara, fácil e urbana. No caso árcade, esse meio-termo foi entendido como apto para figurar os ideais civis e civilizatórios de novos tipos urbanos da ilustração católica portuguesa, disfarçada sob a máscara ou o fingimento da simplicidade não vulgar e não afetada de pastores. Como qualidades que tornam a poesia adequada para figurar a conversação civil, estabelecem $\mathrm{o}$ compromisso ético de sabedoria civilizada e etiqueta galante. (HANSEN, 1997, p. 44-45.)
\end{abstract}

Em termos formais, a análise da lira I,1 põe em relevo um traço comum aos poemas de Marília de Dirceu: a construção estrófica. Gonzaga não adotou formas fixas, como fez Claudio Manuel da Costa com o soneto, ${ }^{70}$ mas plasmou uma forma poética que tem seu núcleo na estrofe. Trata-se de uma escolha adequada tanto à variedade como à

\footnotetext{
${ }^{69}$ HANSEN, João Adolfo. As liras de Gonzaga: entre retórica e valor de troca. Revista Via Atlântica, n. 1, mar. 1997.

${ }^{70}$ Hélio Lopes aponta a rigorosa obediência a uma mesma estrutura poética em Cláudio Manuel da Costa. Ao seguir a clássica padronização petrarquiana na distribuição rítmica dos quartetos $\mathrm{e}$ dos tercetos $(a b b a / a b b a / c d c / c d c)$, "falta à poesia de Cláudio o ritmo leve das redondilhas maiores tão queridas à lírica portuguesa" e abundantemente empregadas por Gonzaga. Os períodos longos de Cláudio, como orações subordinadas e sintaxe que formula o raciocínio, contrastam com a simplicidade de expressão de Gonzaga, ligeiro ao vazar seus versos em estrofes que apresentam grande variedade métrica e rítmica. LOPES, Hélio. Cláudio, o lírico de Nise. São Paulo: Editora Fernando Pessoa, 1974. P. 189 e 191.
} 
simplicidade do discurso gonzaguiano. A estrofe modelada pelo poeta pode ser analisada pelo uso do metro, da rima, das pausas sintáticas e dos estribilhos.

O quadro a seguir apresenta uma visão geral das liras de Gonzaga da primeira parte quanto à estrofe. A primeira coluna fornece o número da lira; a segunda, o número de estrofes que a compõem; a terceira apresenta as medidas dos versos (número de sílabas poéticas) que formam a estrofe; a quarta coluna mostra o esquema de rimas; e a última, o número de versos na estrofe. ${ }^{71}$

\footnotetext{
${ }^{71}$ Ver ALI, Manoel Said. Versificação portuguesa. Prefácio de Manuel Bandeira. São Paulo: Edusp, 1999. BANDEIRA, Manuel. "Versificação em língua portuguesa", in Enciclopédia Delta-Larousse, v. 6; Rio de Janeiro: Delta, 1964. MATTOSO, Glauco. O sexo do verso: machismo e feminismo na regra da poesia. S/1: s/ed., 2010.
} 
Quadro 4 - Esquema de versos, métrica e rima na estrofe gonzaguiana - Parte 1

\begin{tabular}{|l|c|c|l|c|}
\hline Lira & $\begin{array}{l}\text { Número de } \\
\text { estrofes }\end{array}$ & $\begin{array}{l}\text { Medidas dos } \\
\text { versos }\end{array}$ & $\begin{array}{l}\text { Esquema de rimas }^{\text {de versos }} \\
\text { na estrofe }\end{array}$ \\
\hline I-1 & 7 & $10 / 8$ & abab/cddc//ee & 10 \\
\hline I-2 & 9 & 7 & abac/deec & 8 \\
\hline I-3 & 4 & $10 / 7$ & abcb/deed & 8 \\
\hline I-4 & 12 & 5 & abcbd//ed & 7 \\
\hline I-5 & 8 & 5 & abcbdeefg//higjg & 14 \\
\hline I-6 & 5 & $10 / 6$ & abab/cdc & 7 \\
\hline I-7 & 4 & 7 & abca/deeb//fghg & 12 \\
\hline I-8 & 6 & 7 & abcbdc//efc & 9 \\
\hline I-9 & 8 & $10 / 6$ & abcbdc & 6 \\
\hline I-10 & 9 & 4 & abbc/deec & 8 \\
\hline I-11 & 6 & $10 / 6 / 5$ & abcb/defe//ghih & 12 \\
\hline I-12 & 9 & 4 & abbcd/effgd & 10 \\
\hline I-13 & 13 & 4 & abbcd/effd & 9 \\
\hline I-14 & 6 & $10 / 6$ & abba/cded & 8 \\
\hline I-15 & 4 & $7 / 3$ & abccb/defegh//ih & 13 \\
\hline I-16 & 5 & $7 / 5$ & abcb/cdedfg//hg & 12 \\
\hline I-17 & 10 & 4 & abbcbd/efgfd & 11 \\
\hline I-18 & 8 & $10 / 6$ & abc/dbc & 6 \\
\hline I-19 & 6 & $10 / 6$ & abab/cdc & 7 \\
\hline
\end{tabular}

\begin{tabular}{|l|c|c|l|c|}
\hline $\mathrm{I}-20$ & 5 & 5 & $\mathrm{abc} / \mathrm{dbc}$ & 6 \\
\hline $\mathrm{I}-21$ & 5 & 7 & $\mathrm{abcb} / \mathrm{ddefeg} / \mathrm{hg}$ & 12 \\
\hline $\mathrm{I}-22$ & 7 & $10 / 6$ & $\mathrm{abcb}$ & 4 \\
\hline $\mathrm{I}-23$ & 10 & 4 & $\mathrm{abcb}$ & 4 \\
\hline $\mathrm{I}-24$ & 6 & $10 / 6$ & $\mathrm{abcdc} / \mathrm{efe}$ & 8 \\
\hline $\mathrm{I}-25$ & 14 & 7 & $\mathrm{abbc} / \mathrm{dec}$ & 7 \\
\hline $\mathrm{I}-26$ & 4 & 7 & $\mathrm{abcb}$ & 4 \\
\hline $\mathrm{I}-27$ & 7 & $10 / 6$ & $\mathrm{abcbc} / \mathrm{ded}$ & 8 \\
\hline $\mathrm{I}-28$ & 7 & 5 & $\mathrm{abcb}$ & 4 \\
\hline $\mathrm{I}-29$ & 9 & 7 & $\mathrm{abccb}$ & 5 \\
\hline $\mathrm{I}-30$ & 4 & 7 & $\mathrm{abcb}$ & 4 \\
\hline $\mathrm{I}-31$ & 9 & 4 & $\mathrm{abbc} / \mathrm{deec} / \mathrm{fgc}$ & 11 \\
\hline $\mathrm{I}-32$ & 12 & 7 & $\mathrm{abcb}$ & 4 \\
\hline $\mathrm{I}-33$ & 9 & $7 / 4$ & $\mathrm{abcd} / \mathrm{bd} / / \mathrm{efgf}$ & 10 \\
\hline
\end{tabular}


Levantamento semelhante foi realizado nas liras da segunda parte de Marília de Dirceu.

Quadro 5 - Esquema de versos, métrica e rimas na estrofe gonzaguiana - Parte II

\begin{tabular}{|c|c|c|c|c|}
\hline Lira & $\begin{array}{l}\text { Número de } \\
\text { estrofes }\end{array}$ & $\begin{array}{l}\text { Medidas dos } \\
\text { versos }\end{array}$ & Esquema de rimas & $\begin{array}{c}\mathrm{N}^{\circ} \text { de versos } \\
\text { na estrofe }\end{array}$ \\
\hline III-1 & 11 & $10 / 5$ & $\mathrm{ab} / \mathrm{acb}$ & 5 \\
\hline II-2 & 7 & $10 / 6$ & $a b c b$ & 4 \\
\hline II-3 & 8 & 7 & $\mathrm{abbc} / / \mathrm{dc}$ & 6 \\
\hline II-4 & 9 & $10 / 6$ & $a b c b$ & 4 \\
\hline II-5 & 5 & $10 / 6$ & abcbdc & 6 \\
\hline II-6 & 7 & 4 & abbcd//ed & 7 \\
\hline II-7 & 6 & $6 / 10$ & $\mathrm{abc/bd} / / \mathrm{efe}$ & 8 \\
\hline II-8 & 7 & $10 / 6$ & abcbc/ded & 8 \\
\hline II-9 & 17 & 4 & abcdc & 5 \\
\hline II-10 & 9 & $10 / 6$ & $a b c b$ & 4 \\
\hline II-11 & 6 & $10 / 6$ & aba/cdc & 6 \\
\hline II-12 & 6 & 7 & $\mathrm{abcb} / \mathrm{dedf} / / \mathrm{gf}$ & 10 \\
\hline II-13 & 5 & $6 / 10$ & $\mathrm{abcb} / \mathrm{ded}$ & 7 \\
\hline II-14 & 7 & $10 / 6$ & $\mathrm{aba} / \mathrm{cdec}$ & 7 \\
\hline II-15 & 10 & 10 & $\mathrm{abcb} / \mathrm{dd}$ & 6 \\
\hline II-16 & 6 & 4 & abcbdbdef/gf & 10 \\
\hline II-17 & 6 & $6 / 10$ & abcb/dedff & 9 \\
\hline II-18 & 4 & 5 & abcbd/effd & 9 \\
\hline II-19 & 5 & $6 / 10 / 6$ & $\mathrm{abcb} / \mathrm{ded}$ & 7 \\
\hline II-20 & 13 & 7 & abcbde & 6 \\
\hline II-21 & 9 & $10 / 6$ & abcb & 4 \\
\hline II-22 & 6 & 5 & abbcd//efd & 8 \\
\hline II-23 & 8 & $10 / 6$ & abcb & 4 \\
\hline II-24 & 5 & $10 / 6$ & $\mathrm{abcb} / \mathrm{ded}$ & 7 \\
\hline II-25 & 6 & 4 & abcbdbef/ghhf & 12 \\
\hline II-26 & 9 & $10 / 6$ & abcb & 4 \\
\hline II-27 & 7 & 4 & abcbadef/gf & 9 \\
\hline II-28 & 6 & $6 / 10$ & abacdc & 6 \\
\hline II-29 & 5 & 7 & abcbdb & 6 \\
\hline II-30 & 10 & 4 & $a b c d b$ & 5 \\
\hline II-31 & 16 & $10 / 6$ & aba & 3 \\
\hline II-32 & 10 & 7 & abcbdb & 6 \\
\hline II-33 & 6 & $6 / 10$ & $\mathrm{abcb} / \mathrm{ded}$ & 7 \\
\hline II-34 & 10 & $10 / 6$ & abcb & 4 \\
\hline II-35 & 5 & 5 & abbcd/efgfd & 10 \\
\hline II-36 & 7 & $10 / 6$ & abcb & 4 \\
\hline II-37 & 10 & 7 & abcb & 4 \\
\hline II-38 & 15 & $6 / 10$ & abcbded & 7 \\
\hline
\end{tabular}


Observa-se que as 71 liras de Marília de Dirceu aqui estudadas variam quanto ao número de estrofes, quanto ao total de versos na estrofe, à medida dos versos e ao esquema de rimas empregado. Além disso, podem ou não apresentar estribilho. Cada lira contempla um modelo estrófico próprio, formado por um determinado número de versos, um esquema próprio de rimas e uma determinada medida para os versos. Cada estrofe apresenta, deste modo, um desenho único. O mapeamento da estrutura estrófica das 71 liras que constituem Marília de Dirceu demonstra a diversidade dos esquemas estróficos utilizados pelo poeta, pois cada lira apresenta uma estrutura formal própria, que raramente se repete. Este dado reforça a hipótese de uma composição deliberada para Marília de Dirceu como um livro unitário, com começo, meio e fim, e não como um conjunto de poemas.

Os dois fatores que determinam a extensão das liras são o número de estrofes que as compõem e o número de versos presentes em cada estrofe. Este modelo de composição estrófica permite que o poeta alongue ou encurte suas liras sem afetar a sua estrutura composicional. Também quanto à extensão, as liras de Gonzaga apresentam variedade, tanto em relação ao número de estrofes, quanto em relação ao número de versos em cada estrofe. lira mais breve de Marília de Dirceu é composta por quatro estrofes, e a mais extensa, por dezessete. As estrofes estão assim organizadas.

Quadro 6 - Extensão das estrofes e quantificação de seu emprego

\begin{tabular}{|c|c|c|c|}
\hline $\begin{array}{c}\text { Extensão da } \\
\text { estrofe }\end{array}$ & Parte I & Parte II & Total \\
\hline 3 versos & -- & 1 & 1 \\
\hline 4 versos & 6 & 9 & 15 \\
\hline 5 versos & 1 & 3 & 4 \\
\hline 6 versos & 3 & 8 & 11 \\
\hline 7 versos & 4 & 7 & 11 \\
\hline 8 versos & 6 & 2 & 8 \\
\hline 9 versos & 3 & 4 & 7 \\
\hline 10 versos & 3 & 3 & 6 \\
\hline 11 versos & 2 & - & 2 \\
\hline 12 versos & 4 & 1 & 5 \\
\hline 13 versos & 1 & - & 1 \\
\hline Total & 33 & 38 & 71 \\
\hline
\end{tabular}


A lira mais breve é formada por quatro estrofes de quatro versos, num total de 16 versos (Lira I, 26); e a mais extensa, por 13 estrofes de nove versos, num total de 117 versos (Lira I,13). O molde prevalente são as quadras (têm a extensão de quatro versos) 15 liras, seguidas por sextilhas (estrofes de seis versos) e septilhas (estrofes de sete versos), com 11 ocorrências cada. Em menor número, temos as oitavas (estrofes de oito versos), com oito ocorrências, nonas (estrofes de nove versos), com sete ocorrências e as décimas (estrofes de 10 versos), com seis ocorrências. A seguir, pode-se mencionar uma estrofe irregular de 12 versos, com cinco ocorrências e as quintilhas (versos de cinco sílabas), com quatro ocorrências. Há ainda a presença de outras estrofes irregulares (duas liras de 11 versos e uma lira de 13 versos), além de um terceto (estrofe de três versos). As liras, mesmo extensas, não perdem a unidade formal, pois cada uma é composta por um determinado número de estrofes rigorosamente iguais quanto ao número de versos, à metrificação e ao emprego de rimas.

A singularidade da forma poética de Marília de Dirceu vale a observação de que "na literatura de língua portuguesa, o nome lira é usado praticamente só para os poemas líricos de Tomás Antônio Gonzaga", ${ }^{72}$ embora seja relevante mencionar a Lira dos vinte anos, de Álvares de Azevedo (obra também estruturada em duas partes, vale lembrar).

A precisão, a elegância da pena gonzaguiana e seu domínio do fazer poético são unanimidade entre todos quantos leram seus versos. Escritos a um tempo em que a poesia e suas regras de composição eram patrimônio comum, depurados da leitura e releitura dos clássicos, os versos de Gonzaga apresentam desenvoltura.

Fernando Cristóvão refere a

forma como [Gonzaga] se manteve independente em relação às fontes: Anacreonte, Mosco, Horácio, Catulo, Propércio, Tíbulo, segundo Inocêncio (a); Virgílio, Teócrito, Petrarca, Marmontel, Anacreonte, Horácio, Catulo, Cláudio Manuel da Costa, Camões, segundo Alberto Faria (b). (CRISTÓVÃO, 1996)

Há autores que aproximam a forma poética de Gonzaga com a ode. Num dos trechos dos Autos da Devassa, em depoimento atribuído ao próprio poeta, lê-se que Gonzaga teria dito que "tão tranquilo estava que ia fazer uma ode" ${ }^{73}$ A formulação estrófica seguindo variados padrões métricos e rítmicos, a contida elegância e o decoro da linguagem sugerem uma aproximação com a ode. "Gonzaga deu admirável plasticidade à

\footnotetext{
${ }^{72}$ RODRIGUES, Antônio Medina. Literatura Portuguesa. Ensino Médio. São Paulo: Anglo Sistema de Ensino, 2010. p. 56-57.

${ }^{73}$ Autos da Devassa. Apud CANDIDO, 1970, p. 114.
} 
ode", resume Antônio Candido. ${ }^{74}$ É conhecida a imitação que a lira I,20 faz de uma ode de Anacreonte. ${ }^{75}$

\author{
Em uma frondosa \\ Roseira se abria \\ Um negro botão. \\ Marília adorada \\ O pé lhe torcia \\ Com a branca mão. \\ Nas folhas viçosas \\ A abelha enraivada \\ O corpo escondeu. \\ Tocou-lhe Marília, \\ Na mão descuidada \\ A fera mordeu.
}

Apenas lhe morde, Marília, gritando,

C'o dedo fugiu.

Amor, que no bosque

Estava brincando,

Aos ais acudiu.

Mal viu a rotura

E o sangue espargido,

Que a Deusa mostrou,

Risonho, beijando

$\mathrm{O}$ dedo ofendido,

Assim the falou:

Se tu por tão pouco

O pranto desatas,

Ah! dá-me atenção:

E como daquele

Que feres e matas

Não tens compaixão?

(Marília de Dirceu, Lira I, 20)

${ }_{74}^{74}$ CANDIDO, 1970, p. 109.

75 Ao arrolar as obras de autores franceses que constavam da livraria do conjurado Cônego Luís Vieira da Silva (a maior biblioteca da época em Minas Gerais, arrolada no Autos da Devassa), Eduardo Frieiro menciona uma tradução francesa de Anacreonte, sem especificar quem seria o tradutor: In: FRIEIRO, Eduardo. O diabo na livraria do cônego. 2. edição revista e aumentada. São Paulo: Editora Itatiaia/Edusp, 1981. p. 30. A biblioteca do cônego consistia de 270 obras com cerca de oitocentos volumes. 


\begin{abstract}
Amor um dia rosas colhia; não atentava que uma ocultava o leve insecto que suga o mel.

Trépida zune a abelha, e pune co'o vivo espinho o alvo dedinho d'esse indiscreto, com dor cruel.
\end{abstract}

Amor, gritando, parte chorando, vôa ao materno Regaço terno, e alça, mesquinho, querella tal:

"Ó mãi, socorro! "Vale-me! eu morro!... "Vê! Vê! que dôres! "N'aquelas flores "um dragãozinho "me fez o mal;

"fera mais brava, "mas que voava

"co'umas azinhas

"como estas minhas;

"abelha a chama

"o lavrador."

" - Se uma abelhinha

"tal dor te excita, -

diz Venus: - "pensa

"que dor intensa

"dão a quem ama

"farpões de amor.

(A lyrica de Anacreonte. Trad. Antônio Feliciano de Castilho) ${ }^{76}$

A emulação dos bons autores é patente. Correia $\operatorname{Garção~}^{77}$ pontua que "o poeta que não seguir os Antigos, perderá de todo o norte”. Francisco José Freire, o Cândido Lusitano, explica, em sua Arte poética, o valor da emulação:

\footnotetext{
${ }^{76}$ A lyrica de Anacreonte. Trad. Antônio Feliciano de Castilho. Paris: Typografia de Ad. Lainét et J. Havard, 1866. p. 31-32.

${ }^{77}$ Obras completas, vol. II, p. 135.
} 
não há verdade mais trivial e conhecida do que esta de que igualmente morrem os ricos e os pobres, nem esta proposição causa algum deleite a quem a ouve: mas se revestir esta verdade com ornato poético, dir-se-á com Horácio: mors aequo pulsat pede pauperum tabernas/ regumque turres. E ficará então nova, viva e deleitável, por virtude do novo hábito com que se expressou. (FREIRE, Arte poética ou regras da verdadeira poesia em geral..., t. I, p. 56-57)

A lira I, 22 traz a versão de Gonzaga para essa passagem de Horácio a que se refere o preceptista.

O tempo não respeita a formosura,

E da pálida morte a mão tirana

Arrasa os edifícios dos augustos,

E arrasa a vil choupana.

Cristóvão ${ }^{78}$ observou a presença de Horácio, Anacreonte, Virgílio, Teócrito e Petrarca, fundada mais na forma de imitar: “A imitação dos bons autores é feita por ele mais sobre os enunciados que sobre os processos de enunciação". Cristóvão acrescenta que Gonzaga adota o assunto do modelo ou se vale de "versos ou pensamentos isolados" dos autores clássicos e realiza "o aproveitamento de uma parte do enunciado de um modelo, expandindo-o".

Quanto à referência explícita a poetas antigos dentro da própria obra lírica de Gonzaga, as únicas que temos em Marília de Dirceu são as de Tasso e Petrarca, antecessores do Arcadismo na Itália. Na lira I, 22 o poeta se compara a seus antecessores:

Se não houvesse Tasso, nem Petrarca, Por mais que qualquer delas fosse linda, Já não sabia o mundo se existiram Nem Laura nem Clorinda.

Nas Cartas chilenas, anotamos uma referência a Virgílio, Camões e Tasso como leituras do personagem Dirceu:

O nosso bom Dirceu talvez esteja Com os pés escondidos no capacho; Metido no capote, a ler gostoso O seu Virgílio, o seu Camões e Tasso.

(Carta 3)

\footnotetext{
${ }^{78}$ Op. cit., p. 22-29.
} 
O crítico Alexandre Eulálio, ao comentar a relação de Gonzaga com os poetas que o antecederam, afirma que

Leitor atento dos clássicos gregos e latinos, dos mestres europeus consagrados pela Renascença e pelo Barroco, não se esquece dos contemporâneos imediatos dele; a uns e outros alude quando não os glosa deliberadamente ou cita nas liras. Entre os últimos - Pedro Garção, Basílio da Gama e Cláudio Manuel - recolhe e desenvolve sugestões num animado contraponto intertextual. (EULÁLIO, 1980, p. 11-12)

Uma outra característica que não passou despercebida aos estudiosos que se debruçaram sobre a lírica de Gonzaga é o traço popular de seus versos. Esta é a opinião de Luis de Sousa Rabelo:

Pela sua variedade estrófica, dos versos curtos, com rimas e estribilhos, pela simplicidade genuína do sentimento, esta obra afunda as suas raízes na tradição do lirismo popular e dos cancioneiros medievais. ${ }^{79}$

José Veríssimo lembra como Gonzaga deu às suas liras "as formas das canções italianas e também da redondilha portuguesa". ${ }^{80}$ Teófilo Braga recorre a um dado biográfico para enfatizar o aspecto melodioso dos versos do poeta, ao afirmar que o fato de Gonzaga ter passado a infância na Bahia "não deixou de influir na forma poética das liras suscitada pelo tom das modinhas baianas". ${ }^{81}$ De toda forma, "das nossas tradições poéticas nacionais, da nossa poesia popular, da modinha, em suma, viria a Gonzaga o que de inspiração popular há em sua poesia", defende Veríssimo ${ }^{82}$

Quanto à métrica dos versos, observa-se que Gonzaga se vale de cinco medidas diferentes, que contemplam as suas liras: versos de quatro sílabas, de cinco sílabas (redondilha menor), de seis sílabas, de sete sílabas (redondilha maior) e decassílabos. O engenho de Gonzaga manifesta-se tanto no manejo do verso curto, sincopado, quanto no do verso mais longo. Das 71 liras de Gonzaga, um grande número de liras apresenta versos de mesma medida (26 liras). As estrofes monométricas são compostas por versos de 10, 7 ,

\footnotetext{
${ }^{79}$ Luis de Sousa Rebelo. Verbete "Marília de Dirceu”. In: Coelho, Jacinto do Prado (org.). Op. cit. p. 609.

${ }^{80}$ VERÍSSIMO, José. Estudos de literatura brasileira. $4^{\text {a }}$ série. São Paulo: Edusp, 1977. p. 101.

${ }^{81}$ BRAGA, Teófilo. Filinto Elíseo e os dissidentes da Arcádia. Porto: Lello Irmãos. Apud VERÍSSIMO, José, op. cit. p. 101. A modinha é definida como "um gênero de romança de salão, em vernáculo, e inspirada, quanto à forma, na ária da ópera italiana", em vigor da segunda metade do século XVIII até aproximadamente 1850. (FERREIRA, Aurélio Buarque de Holanda. Novo dicionário da língua portuguesa. Rio de Janeiro: Nova Fronteira, 1978.

${ }^{82}$ A hipótese de Veríssimo pode ser relativizada por uma leitura que enfatize o caráter de "simplicidade afetada" própria do sistema retórico-poético a partir do qual Gonzaga inventa seus versos.
} 
5 e 4 sílabas poéticas. Não há nenhuma ocorrência de estrofes compostas unicamente por versos de seis sílabas. ${ }^{83}$

Entre as estrofes polimétricas, verificam-se as combinações de 10/8, 10/7, 10/6, 10/5 e ainda 7/5,7/4 e 7/3. A maior parte dessas liras que combinam metros diferentes (um total de 30) é formada por versos heroicos e seu quebrado (o verso de seis sílabas). Encontramos ainda uma combinação do decassílabo com a redondilha maior (verso de sete sílabas), como em I,3, com a redondilha menor (verso de cinco sílabas), como em II,1. A redondilha maior pode, por sua vez, combinar-se com a menor, como em I,16, com versos de quatro sílabas e também com versos de três sílabas, como em I,15. Essas medidas combinadas e a diversidade de metros empregados nas estrofes gonzaguianas lembram a poética de Camões em suas Canções. Gonzaga também combina três medidas diferentes, da qual é exemplo a lira I,11, que possui versos de dez, de seis e de cinco sílabas:

Não toques, minha Musa, não, não toques

Na sonorosa lira,

Que às almas, como a minha, namoradas,

Doces canções inspira;

Assopra no clarim, que, apenas soa,

Enche de assombro a terra,

Naquele, a cujo som cantou Homero, Cantou Virgílio a guerra.

Busquemos, ó Musa,

Empresa maior;

Deixemos as ternas

Fadigas de amor.

Pode-se indagar se Gonzaga não estaria, no poema como um todo, tentando metros antigos, gregos e latinos? O estudioso Wolfgang Kayser contesta a possibilidade de adaptação das métricas antigas para as línguas românicas:

A adaptação da métrica antiga das odes também foi tentada nas línguas românicas, ocasionalmente até com a aceitação do sistema quantitativo, i.é., reproduzindo as breves antigas por sílabas breves, e as longas por sílabas longas. Porém, tal como nas literaturas germânicas, onde se tentou a mesma coisa, não pode dar resultado essa tentativa. Nas românicas, foram infrutíferas, no fundo, todas as diligências para utilizar as medidas antigas por meio de uma imitação fiel dos acentos. A maneira românica de sentir o verso repugna tal fixação de todas as ársis e térsis. Na Itália, a discussão estendeu-se pelos séculos fora: Leon Batista Alberti, Ariosto, Trissino, Chiabera e Carducci são os mais conhecidos entre os que na discussão têm tomado parte ativa. (KAYSER, 1997)

\footnotetext{
${ }^{83}$ Nossa hipótese é que os versos de seis sílabas - os decassílabos quebrados - são correlacionados aos versos decassílabos, com os quais na maioria das vezes se combinam.
} 
Kayser refere ainda as tentativas feitas pelos poetas da Arcádia em Portugal: Antônio Correia Garção, Antônio Dinis da Cruz e Silva e Castilho. ${ }^{84}$

A diversidade manifesta-se também no uso que Gonzaga faz das rimas. Se a lira I,1 utiliza apenas versos rimados, há liras em que o uso da rima é mais esparso. Um exemplo é a lira I,15. Dos treze versos da estrofe, apenas oito apresentam rimas e os demais são versos brancos:

\begin{tabular}{lc} 
A minha bela Marília & $\mathrm{a}$ \\
Tem de seu um bom tesouro; & $\mathrm{b}$ \\
Não é, doce Alceu, formado & $\mathrm{c}$ \\
\multicolumn{1}{c}{ Do buscado } & $\mathrm{c}$ \\
Metal louro; & $\mathrm{b}$ \\
É feito de uns alvos dentes, & $\mathrm{d}$ \\
É feito de uns olhos belos, & $\mathrm{e}$ \\
De umas faces graciosas, & $\mathrm{f}$ \\
De crespos, finos cabelos, & $\mathrm{e}$ \\
E de outras graças maiores, & $\mathrm{g}$ \\
Que a natureza lhe deu: & $\mathrm{h}$ \\
Bens que valem sobre a terra, & $\mathrm{i}$ \\
E que têm valor no céu. & $\mathrm{h}$
\end{tabular}

Nas estrofes mais curtas, o emprego da rima alternada em apenas um par de versos $(a b c b)$ é recurso frequente: poemas mantêm esse esquema de rimas. A versatilidade da técnica poética de Gonzaga, no entanto, manifesta-se nas estrofes mais longas, em que um elaborado jogo de compensações combina as medidas dos versos, as rimas e as pausas sintáticas.

$\mathrm{Na}$ lira I,17, a combinação de versos rimados e brancos permite que se mantenham unidos sem se tornarem monótonos:

$\begin{array}{ll}\text { Minha Marília, } & \text { a } \\ \text { Tu enfadada? } & \mathrm{b} \\ \text { Que mão ousada } & \mathrm{b} \\ \text { Perturbar pode } & \mathrm{c} \\ \text { A paz sagrada } & \mathrm{b} \\ \text { Do peito teu? } & \mathrm{d} \\ \quad \text { Porém que muito } & \mathrm{e} \\ \text { Que irado esteja } & \mathrm{f} \\ \text { O teu semblante, } & \mathrm{g} \\ \text { Também troveja } & \mathrm{f} \\ \text { O claro céu. } & \mathrm{d}\end{array}$

\footnotetext{
${ }^{84}$ KAYSER, Wolfgang. Análise e interpretação da obra literária (Introdução à Ciência da Literatura). Trad. Paulo Quintela. Coimbra: Arménio Amado, 1967, v. I, p. 133-134.
} 
Em outros, no entanto, a utilização da rima é mais abundante: todos os versos ou a maioria deles são rimados. Vejamos no poema I,10 como a similaridade das duas partes da estrofe é reforçada pela identidade sonora dos últimos versos de cada parte. Em cada quarteto, o primeiro verso é branco, o segundo e o terceiro rimam entre si e o quarto rima com o oitavo.

$\begin{array}{ll}\text { Se existe um peito, } & \text { a } \\ \text { Que isento viva } & \text { b } \\ \text { Da chama ativa, } & \text { b } \\ \text { Que acende Amor, } & \text { c } \\ \quad \text { Ah! Não habite } & \text { d } \\ \text { Neste montado, } & \text { e } \\ \text { Fuja apressado } & \text { e } \\ \text { Do vil traidor. } & \text { c }\end{array}$

A versificação de Gonzaga foi um dos pontos que mais chamou a atenção de seus críticos. Joaquim Norberto de Souza já observava as regras de harmonia implícitas na maneira de versificar de Gonzaga:

Tanto na primeira como na segunda parte de suas liras, seguiu sempre Tomás Antônio Gonzaga o emprego das (rimas) consoantes, observando, à maneira dos italianos e franceses, certas regras acerca da colocação das rimas agudas e graves, sendo que nas composições de arte maior ${ }^{85}$ apenas empregou estas últimas. Nas composições de arte menor usou de umas e de outras intercaladamente, mas sempre debaixo de certa ordem, isto é, às rimas graves seguem as agudas, e é com essas que fecha os seus períodos ou estrofes. Há por assim dizer uma simetria tão constante que, estabelecida a ordem de colocação das rimas graves e agudas na primeira estrofe de uma lira, jamais altera e vai assim até o fim, observando restritamente o preceito a que se impusera. Nota-se ainda mais que entre os milhares de versos que formam a primeira e a segunda parte de suas liras não há um só que seja esdrúxulo, quer livre quer rimado. ${ }^{86}$

\footnotetext{
${ }^{85}$ A lista a seguir indica alguns conceitos que utilizamos presentes em MATTOSO, Tratado de versificação: verso alexandrino, verso de doze sílabas. Verso assinarteto: verso composto de duas partes com métricas distintas. Verso branco: verso sem rima. Verso de arte-maior: verso de oito ou mais sílabas com pausas na terceira, sexta e nona sílabas; arte-maior. Verso de arte-menor: verso que possui menos de oito sílabas, sem esquema rigoroso de acento; arte-menor. Verso de pé quebrado: verso em que a métrica e/ou o ritmo fogem a qualquer regra ou convenção, sem se importar com número de sílabas ou com sua tonicidade. Verso livre: verso sem rima, sem regularidade métrica. Verso métrico: cada uma das linhas que formam um poema quando, como no grego e no latim, as palavras que o compõem são escolhidas segundo a quantidade longa ou breve de suas sílabas. Verso solto: verso branco colocado entre versos rimados. Versos emparelhados: versos que rimam dois a dois. Versos encadeados: versos em que a última palavra do primeiro deles rima com uma palavra do meio do verso seguinte. Versos interpolados: versos que rimam entre si, mas permeados de um até seis versos de rima diferente. Versos rimados: versos em que as palavras finais apresentam rima consoante.

${ }^{86}$ SOUZA, Joaquim Norberto de. Introdução a Marília de Dirceu, 1862, p. 11.
} 
Tal fato corrobora a presença de um traço acentuado da norma na poética de Gonzaga. A simetria entre as duas partes da estrofe pode ser conseguida também pela disposição das rimas, como em II, $28(a b a / c d c)$ :

Sou tronco e rocha, ó bela, $\quad$ a

Que açoita o Sul, que brama, b

E o Mar, que se encapela. a

Não temas que do rosto a cor se mude: c

Vence as rochas e os troncos d

A sólida virtude.

Todas as estrofes mais longas apresentam divisão interna, proporcionada ora pelo metro, ora pela rima, ora por pausas sintáticas, ou ainda por uma combinação entre os três elementos. A estrofe da lira II, 7 fornece um bom exemplo dessa combinação.

Meu prezado Glauceste,

Se fazes o conceito,

Que, bem que réu, abrigo

A cândida Virtude no meu peito;

Se julgas, digo, que mereço ainda

Da tua mão socorro;

Ah! Vem dar-mo agora,

Agora, sim, que morro!

Nela podemos identificar diferentes divisões internas, segundo o critério utilizado. Do ponto de vista métrico, a estrofe possui versos decassílabos e versos de seis sílabas. Podemos dividir os oito versos da estrofe em três partes: uma de dois versos (de seis sílabas), uma de três (decassílabos) e mais uma de três versos (de seis sílabas). Entretanto, se considerarmos o esquema de rimas, observamos que a estrofe divide-se em duas partes simétricas, de quatro versos: abcb/defe. Se analisada de acordo com as pausas sintáticas, a estrofe se divide novamente em três partes, desta vez de quatro, dois e mais dois versos. O efeito geral extraído dessa variedade a reforça a dramaticidade do tema tratado.

Há liras que apresentam versos que rimam com versos de outras estrofes. Na lira II, 20, por exemplo, os últimos versos de todas as treze estrofes rimam entre si (abcbde/ abcbde/ abcbde e assim por diante).

Se me visses com teus olhos

Nesta masmorra metido, De mil ideias funestas

E cuidados combatido, Qual seria, ó minha bela, Qual seria o teu pesar? 


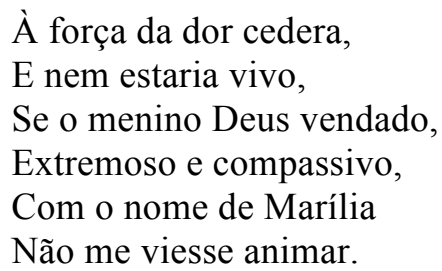

As rimas também podem incorporar o estribilho ao corpo da estrofe, como ocorre nos dois últimos versos de cada estrofe da Lira I,16.

.Eu, Glauceste, não duvido

Ser a tua Eulina amada

Pastora formosa,

Pastora engraçada.

Vejo a sua cor de rosa,

Vejo o seu olhar divino,

Vejo os seus purpúreos beiços,

Vejo o peito cristalino;

Nem há cousa que assemelhe

Ao crespo cabelo louro.

Ah, que a tua Eulina vale,

Vale um imenso tesouro!

Ela vence muito, e muito

À laranjeira copada,

Estando de flores,

$E$ de frutos ornada.

É, Glauceste, os teus Amores;

E nem por outra Pastora,

Que menos dotes tivera,

Ou que menos bela fora,

O meu Glauceste cansara

As divinas cordas de ouro.

Ah! que a tua Eulina vale,

Vale um imenso tesouro!

Sim, Eulina é uma Deusa;

Mas anima a formosura

De uma alma de fera

Ou inda mais dura.

Ah! quando Dirceu pondera

Que o seu Glauceste suspira,

Perde, perde o sofrimento,

E qual enfermo delira!

Tenha embora brancas faces,

Meigos olhos, fios de ouro,

A tua Eulina não vale,

Não vale imenso tesouro.

O fuzil, que imita a cobra,

Também aos olhos é belo: 
Mas quando alumeia,

Tu tremes de vê-lo.

Que importa se mostra cheia

De mil belezas a ingrata?

Não se julga formosura

A formosura, que mata.

Evita, Glauceste, evita

O teu estrago, e desdouro;

A tua Eulina não vale,

Não vale imenso tesouro.

A minha Marília quanto

À natureza não deve!

Tem divino rosto,

$\mathrm{E}$ tem mãos de neve.

Se mostro na face o gosto,

Ri-se Marília contente;

Se canto, canta comigo;

E apenas triste me sente,

Limpa os olhos com as tranças

Do fino cabelo louro.

A minha Marília vale,

Vale um imenso tesouro.

Há liras em que o estribilho apresenta autonomia sonora, isto é, tem seu próprio esquema de rimas, independente da estrofe a que se liga. Ainda assim, a presença do estribilho confere unidade aos poemas mais longos e mantém a função principal de matizar $\mathrm{o}$ andamento dos versos.

O largo emprego do estribilho por Gonzaga também é marcado pela variedade. Há liras que utilizam o estribilho e aquelas que o dispensam. Os estribilhos também variam em extensão, podendo ocupar 2, 3, 4 ou 5 versos. Quanto à sua relação com os demais versos da estrofe, o estribilho pode representar uma continuidade, aproximando-se dos outros versos no plano semântico, ou mostrar certa autonomia, relacionando-se com os demais versos da estrofe de diversas maneiras, seja por afastamento ou por contraste. Em todos os casos, pode-se afirmar que o estribilho matiza a expressão, ocupando função importante nas liras, como veremos adiante.

Há também outro critério pelo qual se pode analisar os estribilhos: eles podem ser iguais em todas as estrofes ou podem apresentar pequenas alterações ao longo da lira.. Frequentes são os estribilhos de apenas dois versos, como na Lira I,16, que reproduzimos acima. O estribilho pode, no entanto, dilatar-se por todo um quarteto, como em I, 33 :

Ah! pinta, pinta

A minha bela!

E em nada a cópia

Se afaste dela. 
Há também estribilhos de três versos, como em II, 22,

Mas ah! Que não treme

Não treme de susto

O meu coração.

Como também depreendemos nos dois últimos exemplos, o estribilho pode ser exclamativo e enfático, o que acarreta uma mudança no andamento do poema. Há estribilhos em que a forma exclamativa é fortemente enfatizada. O recorte do estribilho dáse não apenas pela ênfase, mas também por meio da repetição de termos, trechos de versos e mesmo versos inteiros. A repetição matiza o estribilho, modulando a expressão. No exemplo seguinte, o apelo do eu poético adquire contornos dramáticos:

\footnotetext{
Ah! Socorre, Amor, socorre

Ao mais grato empenho meu!

Voa sobre os astros, voa

Traze-me as tintas do Céu. (I, 7)
}

Nesta lira, a repetição do termo "socorre" é duplicada pela repetição do termo "voa", que precisa o tipo de socorro que o poeta pede. A dicção apelativa e imprecativa do estribilho é assim valorizada. Nessa mesma lira, observamos que o estribilho é modulado ainda mais ativamente se levarmos em conta a construção do poema. Isto se dá por uma alteração do seu teor ao final da lira, em vista do transcorrer do enunciado. Na última estrofe o estribilho altera-se com uma elocução conclusiva:

\footnotetext{
Vai-te, amor, em vão socorres Ao mais grato empenho meu: Para formar-lhe um retrato Não bastam as tintas do Céu.
}

O estribilho pode sofrer uma torção e redundar no seu contrário, como em II, 16:

Mas inda sofro

A viva dor.

E logo a seguir:

Eu já não sofro A viva dor.

Nesta lira, a alteração do estribilho corta a lira ao meio, em três estrofes afirmativas e três negativas. 
Na Lira II, 12, o estribilho mantém-se inalterado nas cinco primeiras estrofes:

Ah! Marília, que tormento

Não tens de sentir saudosa!

Não podem ver os teus olhos

A campina deleitosa,

Nem a tua mesma aldeia,

Que tiranos não proponham

À inda inquieta idéia

Uma imagem de aflição.

Mandarás aos surdos Deuses

Novos suspiros em vão.

Quando levares, Marília,

Teu ledo rebanho ao prado,

Tu dirás: Aqui trazia

Dirceu também o seu gado.

Verás os sítios ditosos

Onde, Marília, te dava

Doces beijos amorosos

Nos dedos da branca mão.

Mandarás aos surdos Deuses

Novos suspiros em vão.

Quando à janela saíres,

Sem quereres, descuidada,

Tu versa, Marília, a minha

E minha pobre morada.

Tu dirás então contigo:

Ali Dirceu esperava

Para me levar consigo;

E ali sofreu a prisão.

Mandarás aos surdos Deuses

Novos suspiros em vão.

Quando vires igualmente

Do caro Glauceste a choça,

Onde alegre se juntavam

Os poucos da escolha nossa,

Pondo os olhos na varanda

Tu dirás, de mágoa cheia:

Todo o congresso ali anda,

Só o meu amado não.'

Mandarás aos surdos Deuses

Novos suspiros em vão.

Quando passar pela rua

O meu companheiro honrado,

Sem que me vejas com ele

Caminhar emparelhado,

Tu dirás: Não foi tirana

Somente comigo a sorte;

Também cortou desumana

A mais fiel união. 
Mandarás aos surdos Deuses

Novos suspiros em vão.

Na sexta e última estrofes, ele soma à sua voz a voz do interlocutor:

Numa masmorra metido, Eu não vejo imagens destas, Imagens, que são por certo

A quem adora funestas.

Mas se existem separadas

Dos inchados, roxos olhos,

Estão, que é mais, retratadas

No fundo do coração.

Também mando aos surdos Deuses

Tristes suspiros em vão.

Com este procedimento, a suposição do eu poético de que Marília suspira pela sua triste condição é neste momento fundamentada e explicada.

Em determinadas liras, como em II,3, o estribilho modifica-se a cada estrofe, referendando o tema de cada uma.

Sucede, Marília bela,

À medonha noite o dia;

A estação chuvosa e fria

À quente, seca estação.

Muda-se a sorte dos tempos;

Só a minha sorte não?

Os troncos nas Primaveras

Brotam em flores viçosos;

Nos invernos escabrosos

Largam as folhas no chão.

Muda-se a sorte dos troncos;

Só a minha sorte não?

Aos brutos, Marília, cortam

Armadas redes os passos;

Rompem depois os seus laços,

Fogem da dura prisão.

Muda-se a sorte dos brutos;

Só a minha sorte não?

Nenhum dos homens conserva

Alegre sempre o seu rosto;

Depois das penas vem gosto,

Depois de gosto aflição.

Muda-se a sorte dos homens;

Só a minha sorte não?

Aos altos Deuses moveram 
Soberbos Gigantes guerra;

No mais tempo o Céu e a Terra

Lhes tributa adoração.

Muda-se a sorte dos Deuses;

Só a minha sorte não?

Há de, Marília, mudar-se

Do destino a inclemência;

Tenho por mim a inocência,

Tenho por mim a razão.

Muda-se a sorte de tudo;

Só a minha sorte não?

O tempo, ó Bela, que gasta

Os troncos, pedras, e o cobre,

$O$ véu rompe, com que encobre

À verdade a vil traição.

Muda-se a sorte de tudo;

Só a minha sorte não?

Qual eu sou verá o mundo;

Mais me dará do que eu tinha,

Tornarei a ver-te minha;

Que feliz consolação!

Não há de tudo mudar-se;

Só a minha sorte não.

Deste modo, a interrogação da primeira estrofe ("Muda-se a sorte dos tempos; só a minha sorte não?”) serve de paradigma aos outros estribilhos, em que a palavra /tempos/ é sucessivamente trocada por /troncos/, /brutos/, /homens/, /deuses/, em gradação. O estribilho da sexta estrofe resume as questões levantadas nas cinco anteriores: "Muda-se a sorte de tudo; só a minha sorte não?" e será sustentado sem mudanças por mais uma estrofe. Na última, a interrogação transforma-se numa exclamação de tom conclusivo que reformula o conteúdo dos estribilhos anteriores: "Não há de tudo mudar-se,/só a minha sorte não!”.

A variedade da fatura poética de Gonzaga é patente no campo da sonoridade. No plano fonológico notamos, além da rimas consoantes em final de verso, o uso da aliteração (tosco trato, minha Marília, tendo tantos, palavras os pastores) e o de rimas internas toantes (vaqueiro/alheio, gado/trato). Os recursos fonológicos são usados com função expressiva, como é o caso do $r$ intercalado, que reforça a rusticidade aludida no plano semântico em "de tosco trato, de expressões grosseiro", em que as consoantes iniciais do encontro consonantal se alternam, ou o outro caso em que o acúmulo de nasais reproduz as 
ondulações das águas na fonte em "eu vi o meu semblante numa fonte/ dos anos inda não está cortado".

Se a intencional simplicidade vocabular faz-se acompanhar de um discreto uso de figuras de linguagem, no plano da construção as figuras são fortemente empregadas: emparelhamento de palavras da mesma classe gramatical ("papoula ou rosa", "delicada e fina”), duplicação de sintagmas em construções disjuntivas ("Ou seja neste monte ou noutra serra”), enumeração (“dá-me vinho, legume, fruta, azeite”) e o abundante emprego da repetição: "Nossos corpos terão, terão a sorte", "acabe, acabe a peste matadora" ${ }^{87}$

Os efeitos que Gonzaga obtém da modulação de seus versos são extraídos sobretudo pela flexibilidade sintática, que permite uma infinidade de efeitos expressivos. São frequentes as inversões, desde a simples anteposição do substantivo ao adjetivo ("alheio gado", "tosco trato", "clara fonte"), passando pela inversão do consequente e do antecedente ("para glória de amor igual tesouro" ou "lerão estas palavras os pastores") até a inversão total da ordem da oração: "que inveja até me tem o próprio Alceste". Há hipérbatos mais violentos, cobrindo dois versos: "acabe, acabe a peste matadora/ sem deixar uma rês, o nédio gado". Em certos casos, o hipérbato adquire a forma mais forte da anástrofe: "dos frios gelos e dos sóis queimado", "do que tenho ser senhora” ou "dos anos inda não está cortado".

Notamos ainda a presença de orações restritivas, intercaladas na formulação direta.

c'os filhos, se os tivermos, à lareira

Ou ainda:

entre as falsas histórias, que contares, lhe contarás a minha, verdadeira.

A antítese, nesse último caso, torna a formulação oblíqua. ${ }^{88} \mathrm{~A}$ lira I,1, inteiramente vazada no decassílabo, deixa entrever o peculiar recorte rítmico de Gonzaga. Recursos

\footnotetext{
${ }^{87}$ Trata-se da figura retórica da epizeuxe, que consiste em repetir seguidamente a mesma palavra para simplificar, imprimir compaixão ou exortar.

${ }^{88} \mathrm{O}$ estudioso Marques Braga estabelece uma comparação entre Gonzaga e o poeta humanista Antônio Ferreira: "Um dos poetas que mais se aproximam de Gonzaga em termos de elaboração sintática é o português Antônio Ferreira. Recortes rítmicos muito semelhantes aos de Gonzaga estão presentes nos Poemas lusitanos. Rica pontuação, presença de orações exclamativas e interrogativas, efeitos de interrupção e pausa fazem parte de sua poética. Neste quarteto, por exemplo, podemos notar o emprego da ordem invertida, a simetria no primeiro verso e o efeito de acréscimo no último: "Em vossos peitos sãos, limpos ouvidos/Caiam meus versos, quais me Febo inspira!/Eu desta glória só fico contente,/que a minha terra amei,
} 
como a repetição e a inversão agilizam o verso, permitindo ao poeta deslocar os acentos secundários e mudar a ênfase dos enunciados. Ao intercalar o vocativo, no exemplo abaixo, o poeta cria um efeito de suspense para o leitor, retardando a informação:

É bom, minha Marília, é bom ser dono

De um rebanho que cubra monte e prado.

Neste outro caso, o mesmo recurso reforça o sentido de "suspensão" que o poeta expressa:

Sustentada, Marília, nos meus braços

Frequentemente os pontos de exclamação ou de interrogação, assim como as aspas e os hifens, modulam o discurso para produzir efeitos de sentido. Como já observamos, há emprego de inversões, repetições e intercalações. No plano semântico, podemos ressaltar o uso de orações negativas e das litotes.

Eu, Marília, não sou algum vaqueiro Que viva de guardar alheio gado.

$\mathrm{Ou}$

Eu vi o meu semblante numa fonte

Dos anos inda não está cortado.

O contraste é obtido não apenas pela oposição, negação ou comparação, como nos casos acima, mas também pela comparação implícita. Aqui, a vivacidade do discurso é reforçada pela comparação subentendida,

Os pastores que habitam este monte

Respeitam o poder do meu cajado.

O mesmo ocorre quando é mencionado Alceste, cuja presença introduz um elemento de comparação ainda mais forte.

Com tal destreza toco a sanfoninha

Que inveja até me tem o próprio Alceste.

Há emprego de comparações, imagens e hipérboles.

e a minha gente!”. In FERREIRA, Antônio. Poemas lusitanos. Pref. e notas do prof. Marques Braga, v. I. Lisboa: Sá da Costa, 1939. 
Os teus olhos espalham luz divina

A quem a luz do sol em vão se atreve.

Neste outro exemplo, a intensificação é conseguida por uma duplicação da comparação.

Porém, gentil Marília, o teu agrado

Vale mais que um rebanho e mais que um trono.

A comparação pode acolher uma hipérbole.

Ah! Não fez o Céu, gentil pastora,

Para Glória de amor igual Tesouro.

A hipérbole logo adiante adquire um cunho dramático.

Acabe, acabe a peste matadora,

Sem deixar uma rês, o nédio gado.

Note-se como a comparação está implícita na negação. A dificuldade em apreender a complexidade do discurso de Gonzaga está em que, aparentando uma forjada "naturalidade", ele não utiliza apenas figuras explícitas, mas faz uso de recursos não reconhecíveis à primeira vista. A elaboração semântica parece dar-se num momento anterior ao da enunciação, e todas as operações mentais envolvidas se dissolvem em orações declarativas e lisas sintaticamente. Nas palavras de Alexandre Eulálio, Gonzaga "as mais das vezes leva a palma dos pares pelo caráter aliciante, incisivo e sedutor, das soluções estilísticas que recorta, - pois a firmeza da garra gonzaguiana, servida por uma singular euforia imaginativa, torna quase sempre lapidar a elocução dele““ 89

Em outras liras, no entanto, a presença da rima em todos os versos confere grande coesão à estrofe. Em I,10, a similaridade formal das duas partes da estrofe é reforçada pela identidade sonora dos dois últimos versos de cada parte:

\begin{tabular}{ll} 
Se existe um peito, & $\mathrm{a}$ \\
Que isento viva & $\mathrm{b}$ \\
Da chama ativa, & $\mathrm{b}$ \\
Que acende Amor, & $\mathrm{c}$ \\
\multicolumn{1}{c}{ Ah! não habite } & $\mathrm{d}$ \\
Neste montado, & $\mathrm{e}$ \\
Fuja apressado & $\mathrm{e}$ \\
Do vil traidor. & $\mathrm{c}$
\end{tabular}

\footnotetext{
${ }^{89}$ EULÁLIO, 1983, p. 12.
} 
A semelhança entre as duas partes da estrofe pode ser conseguida também por efeito de simetria, como em II, $28(a b a / c d c)$ :

$\begin{array}{cc}\text { Sou tronco e rocha, ó bela, } & \mathrm{a} \\ \text { Que açoita o Sul, que brama, } & \mathrm{b} \\ \text { E o Mar, que se encapela. } & \mathrm{a} \\ \text { Não temas que do rosto a cor se mude: } & \mathrm{c} \\ \text { Vence as rochas e os troncos } & \mathrm{d} \\ \text { A sólida virtude. } & \mathrm{c}\end{array}$

As estrofes mais longas revelam nítida divisão interna, proporcionada ora pela rima, ora por pausas sintáticas ou ainda por uma combinação de ambos. A primeira estrofe da lira II,7 é um bom exemplo de como esses elementos se combinam numa mesma arquitetura poética:

\begin{tabular}{ll} 
Vou retratar a Marília, & $\mathrm{a}$ \\
A Marília, meus amores; & $\mathrm{b}$ \\
Porém como? se eu não vejo & $\mathrm{c}$ \\
Quem me empreste as finas cores? & $\mathrm{b}$ \\
Dar-mos a terra não pode; & $\mathrm{d}$ \\
Não, que a sua cor mimosa & $\mathrm{e}$ \\
Vence o lírio, vence a rosa, & $\mathrm{e}$ \\
O jasmim e as outras flores. & $\mathrm{b}$ \\
\multicolumn{1}{|c}{ Ah! socorre, Amor, socorre } & $\mathrm{a}$ \\
Ao mais grato empenho meu! & $\mathrm{b}$ \\
\multicolumn{1}{c}{ Voa sobre os astros, voa, } & $\mathrm{c}$ \\
Traze-me as tintas do Céu. & $\mathrm{a}$
\end{tabular}

Se analisarmos as rimas utilizadas pelo poeta, veremos que o corpo da estrofe e o estribilho sugerem descontinuidade. $\mathrm{O}$ estribilho tem autonomia rimática, não se ligando a nenhum outro verso da estrofe. Considerando apenas o corpo da estrofe, notamos que o poeta utiliza apenas duas diferentes rimas, a que aproxima os versos 2, 4 e 8 , e a outra que aproxima os versos 6 e 7. Entre eles estão versos soltos. Considerando as pausas sintáticas, podemos fazer outro agrupamento. Os dois primeiros versos, assim como o terceiro e o quarto podem ser considerados dois dísticos, enfeixando o primeiro o problema colocado pelo poeta, e o segundo, a tentativa de solução. Os dois pares de versos integram um mesmo período, porém se distinguem pelo tom declarativo e interrogativo, respectivamente. A seguir, temos um quarteto preenchido por um único período, que descreve a formosura de Marília.

Em termos formais, o volume Marília de Dirceu (formado por dois livros) revela unidade, como já vimos, com estrofes perfeitamente homogêneas em sua estrutura, costuradas ou não pelo estribilho. Em termos temáticos, são fatores aglutinantes do poemaa 
fidelidade ao imaginário pastoril e a presença de Marília, por outro. O que vale para a lira I,1 vale, podemos inferir, para a poética de Tomás Antônio Gonzaga em geral. A interpretação literal da lira I,1 não oferece maiores dificuldades. Ao analisar outra lira de Gonzaga, a II,15, Antônio Candido comenta como, em Gonzaga "a tonalidade geral do discurso corresponde à simplicidade do assunto" (CANDIDO, 2005). O estudioso nota o enunciado direto, a objetividade e a ausência de linguagem figurada. Acrescenta, entretanto, que à força da alegoria pastoril, "no seu todo o poema é figurado".

Graças à própria natureza da poesia pastoril, que pressupõe uma visão que se pode chamar de alegórica da vida. De fato, nele existe, sob a expressão direta, um sistema complexo de significados indiretos (...), pois ela reduz homens cultos, de bom nível social, a uma condição de modesta rusticidade, que é simulada. O leitor entra no jogo e finge acreditar, sabendo que a simplicidade não é apenas relativa, mas altamente convencional, pois há uma contradição básica, deformadora, entre o plano explícito e o plano implícito.

"Eu, Marília, não fui nenhum vaqueiro

Fui honrado pastor da tua aldeia"

Significa alegoricamente: "Eu, Marília, não fui uma pessoa de condição social inferior, mas alguém que exercia alto cargo público, e como tal era respeitado na tua vila". ${ }^{90}$

Embora note-se um fundo biográfico em sua observação, o estudioso mostra, ainda, que "a simplicidade da expressão corresponde à simplicidade da alegada condição social, mas com um elemento implícito de distorção, que é a alegoria, funcionando como disfarce da condição verdadeira". ${ }^{91}$ Haveria um conflito entre a rusticidade do assunto e o refinamento efetivo do emissor do enunciado, que Candido chama de "curioso disfarce". ${ }^{2}$

Levando em conta o caráter convencional desta poesia, podemos compreender melhor como o leitor é arrastado para dentro do poema, entrando em contato direto com a realidade fingida. Para dar forma ao idílio pastoril, o poeta faz-se pastor, vivendo em casal, tirando do rebanho e dos roçados seu sustento, tocando a sanfoninha e vivendo entre outros pastores. $\mathrm{O}$ enunciador instaura um discurso apoiado numa interlocutora - Marília -, o que dá um tom singular à poética de Gonzaga. De certa forma, Marília ocupa o lugar do leitor, a quem o poema é endereçado. O registro da interlocução (em que Marília não se manifesta explicitamente) se mantém no transcorrer de todo o poema I,1, porém adquire diversos matizes, como veremos adiante.

\footnotetext{
${ }^{90}$ CANDIDO, Antônio. Na sala de aula, p. 23.

${ }^{91}$ Idem, p. 24

${ }^{92}$ Idem, ibidem.
} 
A interlocução permite um contraponto, no qual o foco se concentra ora num ora noutro interlocutor. É significativo que essa lira seja de Marília de Dirceu: o poeta se apresenta ao leitor de maneira dissimulada, oblíqua, fingindo estar falando diretamente com Marília. O leitor é introduzido a este universo fabulado - a alegoria pastoril - como se sempre nele tivesse estado. Trata-se de um jogo cujas regras estão dadas de antemão: um diálogo entre pastores, entre iguais.

Certos aspectos da poética de Tomás Antônio Gonzaga só se esclarecem com a leitura integral da lira $\mathrm{I}, 1$, estrofe a estrofe. $\mathrm{O}$ assunto desta lira parece se constituir à medida que o poema avança. A produção de sentido depende da leitura sequencial do poema e da maneira como as estrofes se encadeiam umas com as outras.

Gonzaga faz coincidir o plano do enunciado com o plano da enunciação. Por isso, o poema se constrói no presente, no momento da leitura, o que responde em parte pelo caráter vívido e vigoroso da poética de Gonzaga. Nesta lira, há um enunciador que organiza o discurso, dividindo os assuntos e organizando-os nas estrofes. que é ao mesmo tempo a persona poética, que evoca, sonha, lembra, deseja, duvida ou imagina. Tudo isto é encenado no momento da leitura diante do leitor e com sua participação. Cada estrofe apresenta certa autonomia de sentido, mas sua sequência dentro da lira gera tensão e movimento.

Um dos aspectos desta modulação do discurso (em diferentes "atitudes” poéticas) se faz por meio da sintaxe, no uso dos tempos verbais. Os verbos criam recuos ou avanços, e possibilitam representar as diferentes atitudes da persona poética - o desejo, a memória, a racionalidade, que permite a formulação de hipóteses e suposições. Por trás da aparente simplicidade do que é dito, há um jogo de tensões internas, em que versos e estrofes se referem uns aos outros e se refazem, em que o que é afirmado é depois negado, problematizado ou reelaborado. Esta dinâmica combina-se com a dinâmica da interlocução, o que dá uma medida da complexidade estrutural do discurso de Gonzaga.

O estribilho também desempenha papel importante na composição das liras, pois, em alguns casos, permite a transição de uma estrofe à outra. Ele também pode instaurar um discurso paralelo, em outros casos, que amortiza as descontinuidades entre as estrofes e faz ressoar as mesmas notas básicas em toda a lira. Num movimento dialético, no entanto, o sentido de cada estrofe modifica o sentido do estribilho, nuançando seu significado.

Tomaremos a lira I,1 como programática pois ela define a poética de Marília de Dirceu e a matéria, a invenção e a elocução de seu discurso. Na primeira estrofe, a persona poética fala de si mesma e de sua condição material e social. O entorno é criado para que 
este eu possa se projetar dentro dele: "não sou algum vaqueiro que viva de guardar alheio gado". O poeta cria a figura do pastor rústico apenas para dela se afastar. Ele não se limita a introduzir o cenário pastoril e colocar-se dentro dele. Seu disfarce poético necessita ser singularizado.

Em termos de ponto de vista, o eu poético se coloca numa esfera doméstica, proprietário de seu casal - sua propriedade rústica. Num tom sereno e contido, o eu poético vai explicitar quem é e como vive, ao leitor e a Marília, usando o tempo presente dos verbos. A segunda estrofe reforça e amplifica aquilo que foi estabelecido na primeira. A placidez do discurso, feito de longas orações, permanece. Partindo de sua própria habitação, o poeta amplia seus domínios. Sai de casa para tratar dos "pastores que habitam este monte". Introduz a fonte e passa a povoar o espaço poético de figuras que participam da cena pastoril. Ao mesmo tempo que compõe este cenário, elenca outras personagens para criar situações de interlocução: outros pastores e Alceste. Esta estrofe, como a precedente, se organiza em torno do presente. Vale lembrar que o presente é o tempo/aspecto verbal que favorece o discurso em tom encomiástico. $\mathrm{O}$ tempo é amplificado, pois sugere um cotidiano, uma continuidade: "com tal destreza toco", isto é, costumo tocar a sanfoninha. Há um presente contínuo, já embutido na primeira estrofe. $\mathrm{O}$ movimento é de expansão temporal e espacial.

$\mathrm{Na}$ terceira estrofe, o poeta problematiza esta situação harmônica que havia descrito anteriormente. $\mathrm{O}$ movimento de expansão é bruscamente interrompido. $\mathrm{O}$ pastor que falava de si mesmo coloca-se em presença da interlocutora; o andamento do discurso torna-se mais rápido e mais entrecortado. Os volteios manifestam-se num discurso argumentativo que abruptamente irrompe:

\footnotetext{
Mas tendo tantos dotes da ventura, Só apreço lhes dou, gentil pastora, Depois que teu afeto me segura Que queres do que tenho ser senhora.
}

Aquilo que foi afirmado anteriormente, à guiza de explicitude e apresentação (a descrição dos dotes da ventura) transforma-se num argumento para a interlocutora. $\mathrm{O}$ emissor exibe a Marília seus bens e seus dotes para depois usá-los a seu favor. Desqualifica-os, como estratégia argumentativa, ao requisitar o afeto da interlocutora e ao mesmo tempo oferece-lhe todos os seus bens. O falso desapreço a seus dotes e seus bens serve apenas para requisitar o afeto de Marília, para mobilizá-la. O enunciado anterior é 
sumariado, o que foi afirmado nas duas estrofes anteriores transforma-se numa oração subordinada. Há uma expectativa de resposta de Marília a essa oferta.

O que parecia uma descrição isenta, apesar de certa vaidade, transforma-se em galanteio - uma estratégia de conquista do eu poético que, travestido de pastor, exibe-se para sua amada. O pastor se oferece, junto com todos os seus bens, ou melhor, por intermédio de seus bens, à amada. Ao chamá-la pelo nome ("gentil pastora", "minha Marília”) explicita a identidade da interlocutora. A terceira estrofe problematiza uma situação de equilíbrio e harmonia, cria uma tensão entre eu poético e destinatária. $\mathrm{O}$ foco, ao deslizar para a interlocutora, esclarece ao leitor seu verdadeiro papel: Marília é uma pastora, amada do poeta. Ao mesmo tempo, o eu poético adensa o enunciado, ao trasladarse de aspectos exteriores e materiais para aspectos interiores e afetivos. Ele estabelece uma hierarquia: "teu agrado vale mais que um rebanho", e resvala para a hipérbole: "e mais que um trono".

Mantendo o discurso apoiado na interlocutora, o poeta passa então a pintar-lhe um retrato na quarta estrofe. Vale mencionar que, das sete estrofes da lira, esta é a que ocupa a posição central. A persona poética passa de pastor a pintor, seguindo o preceito de Horácio. ${ }^{93}$ Com riqueza de imagens, voltado para a segunda pessoa ("teus olhos", "te cobre as faces", "teus cabelos", "teu lindo corpo") e em tom descritivo, põe-se a louvar as qualidades físicas de Marília. A descrição à primeira vista é objetiva, porém todos os traços da amada são imaterializados, são abstratos, tomados à tradição poética. Marília aparece como detentora de uma formosura abstrata. O poeta faz dela um retrato supostamente físico, mas que não é senão sua glorificação espiritual, voltada para o olhar, a luminosidade. A "Senhora de que tenho" torna-se agora "Tesouro para a Glória do amor". A pintura da amada traça um perfil fora do espaço e do tempo. O tom elevado cria um momento de suspensão dentro do poema. A única ação é a ação verbal de descrever,

\footnotetext{
${ }^{93}$ A expressão deriva de Horácio, que a utiliza em sua Arte Poética com o significado de "como a pintura, a poesia": "Ut pictura poesis: erit quae si propius stet./Te capiat magis: et quaedam si longius abstes./Haec amat obscurum, volet haec sub luce videri.// Judicis argutum quae non formidat acumen:/ Haec placuit semel, haec decies repetita placebit". "A ideia parece ter nascido originariamente com Simónides de Ceus, segundo conta Plutarco citando-o: 'A pintura é uma poesia muda, e a poesia uma pintura falante.' Aristóteles pronunciou-se no mesmo sentido na sua Poética ao definir diversos processos de imitação, logo no primeiro capítulo e, sobretudo, ao afirmar um pouco mais adiante: 'o poeta imita como o pintor ou qualquer outro criador de figuras.' Cícero também não foi indiferente ao paralelismo das duas artes quando encarou a função do "retrato" no uso oratório. E do mesmo modo Quintiliano, que recomendava ao futuro orador o estudo do desenho e da geometria, não só pelo carácter utilitário do estudo das linhas, mas pela afinidade estreita que mantinha com a arte oratória." (CRISTÓVÂO, 1981, p. 53-54.) A popularidade da comparação expande-se no Classicismo e no Neoclassicismo, e se transforma em preceito seguido por diversos poetas.
} 
louvar, glorificar, o que contrasta com a argumentação da estrofe anterior. A pintura da amada, em que Marília reina soberana, é um momento de certo modo isolado dentro do poema. Podemos até afirmar que se trata de seu clímax.

Após este momento, o eu poético começa a refazer seu percurso. A dicção argumentativa da quinta estrofe retoma o discurso da estrofe anterior do retrato. O poeta retorna ao plano material, ao mencionar seus bens, a plantação e o gado. A materialidade, porém, retorna para ser negada. Há um movimento para o coletivo e o genérico. Desindividualizam-se os elementos naturais: "ovelhinha", "vinho", "legume", "fruta", "azeite" tornam-se agora "gado" e "sementeira". O poeta abdica de seus bens, imaginando os campos semeados destruídos e o gado dizimado, introduzindo, deste modo, um elemento de desequilíbrio no harmonioso cenário pastoril. A possibilidade de perder os seus bens por meio de uma cheia devastadora ou da peste contrapõe-se à harmonia entre eu poético e o entorno meticulosamente construído nas duas primeiras estrofes. Este cenário de felicidade, que antes o poeta afirmara, é agora desqualificado. Seus bens agora são colocados no mesmo plano das "paixões que o mundo arrasta". A felicidade que antes declarara ("os dotes da ventura") na posse de seus bens e na vida grada junto aos seus iguais (Alceste e os demais pastores) torna-se insignificante em relação à presença de Marília.

Para viver feliz, Marília, basta

Que os olhos movas, e me dês um riso.

O conteúdo desses versos resulta do contraste entre a vida ideal pintada nas duas primeiras estrofes (eu poético/entorno) e a presença espiritual da amada, pintada na quarta estrofe, e aprofunda o argumento da primeira estrofe. Marília agora não apenas precisa assenhorar-se dos bens dele, mas estar além deles, em novo plano. É importante notar que Marília é descrita nesta quinta estrofe como personagem: ela é flagrada em movimento e expressando-se por meio do riso e do mover dos olhos. Os bens materiais são deixados para trás em razão de sua presença.

A sexta estrofe reelabora a alegoria pastoril, projetando uma nova realidade num terreno distante, no futuro. $\mathrm{O}$ eu poético pinta-se a si mesmo como pastor, em convivência com a interlocutora, também transformada em pastora. Os quadros de enleio amoroso são itinerantes; as personas e e e $t u$ deslocam-se pelo cenário idealizado.

Eu e tu são o eu poético e a interlocutora, ao mesmo tempo desdobrados em pastor e pastora. Entrelaçando-os, o poema de certa forma resolve a tensão que o sustentava - 
essa oscilação de foco ora num ora noutro dos interlocutores. O emparelhamento inicial se refaz. Os dois últimos versos desta estrofe criam, requintadamente, uma equivalência, também, entre o pastor que vive o idílio pastoril e o poeta que louva a amada:

Toucarei teus cabelos de boninas

No tronco gravarei os teus louvores

$\mathrm{Na}$ última estrofe, finalmente, os pastores aparecem como "nós". O idílio, consumado já, transforma o casal em exemplo e modelo. O poema torna-se ainda mais prospectivo, remetendo a um futuro distante, ainda mais longínquo que o da estrofe anterior: "depois que nos ferir a mão da morte". O entorno passa a ser habitado por novos pastores, convertidos momentaneamente em leitores do idílio de Dirceu e Marília.

O poema sugere o movimento de expansão. Esta expansão manifesta-se também espacialmente: do "próprio casal" ao "neste monte" e à "floresta". O locus amplia-se e vaise tornando-se menos determinado; na última estrofe a localização espacial é indiferente (“ou seja neste monte ou noutra serra"), o espaço se universaliza.

Reafirmamos que o que vale para a lira I,1 vale para a poética de Tomás Antônio Gonzaga em geral. Marília de Dirceu se constitui, basicamente, das mesmas tensões que marcam a lira I,1, Embora as estrofes da lira I,1 revelem eventual autonomia de sentido, tornam-se mais ricas e significativas, lidas umas em relação às outras ou, mais precisamente, lidas sequencialmente. De modo análogo, cada lira gonzaguiana possui autonomia de sentido, porém o que torna sólida e significativa a poética de Marília de Dirceu é o fato de que se trata de uma composição, em que as liras referem-se umas às outras. Este jogo de referências é o que torna Marília de Dirceu mais do que uma antologia de poemas do mesmo autor.

Além da constância do imaginário pastoril, vimos como o fator aglutinante das liras (de Marília de Dirceu) é a presença de Marília, posta em tensão com o eu poético. Em I,1, é importante notar como Marília vai-se constituindo à medida que o poema avança, em virtude do relacionamento que estabelece com o eu poético. Embora as torções que ligam uma estrofe à outra permitam visualizar diversas nuanças nesta relação, é possível assinalar claramente três momentos principais: o da interlocução, mais evidente na primeira estrofe, o da quarte estrofe, em que a efígie de Marília é pintada, e o da sexta estrofe, em que ela participa do idílio pastoril. Podemos discernir, desde já, três figuras para Marília: a interlocutora, a figura de retrato e a personagem da cena pastoril. 
CAPÍTULO 3. A força de Marília bela

O meu discurso,

Marília, é reto;

a pena iguala

ao meu afeto;

o amor que nutro

ao teu aspecto

e ao teu semblante,

é singular. 
A presença de Marília não apenas povoa e unifica a lírica gonzaguiana, como reforça seu caráter compósito. Fernando Cristóvão concorda que “a unidade e a beleza especiais dos poemas de Gonzaga lhes advém muito do facto de se apresentarem como múltiplas facetas duma força aglutinante - o tema de Marília” (CRISTÓVÃO, 1981, p. 39). Temos uma persona poética - o pastor Dirceu - a partir da qual se organizam pessoas, tempos e espaços da composição. Seja na campina verdejante, junto de uma fonte clara, ou no cárcere sombrio, a persona poética modula seus argumentos, devaneios e estados imaginários em projeções futuras ou remissões ao passado, diante da interlocutora, em presença dela e do leitor. Esses movimentos se desenrolam no tempo presente, no tempo da enunciação, e vão se tornando "experiência incrustada na sensibilidade". 94 O fato de Marília constituir-se como núcleo organizador da obra poética de Gonzaga foi explicado por Crístóvão (1981, p. 15): “a quase totalidade dos refere-se direta ou indiretamente a Marília, e dela recebe nova força interpretativa. Lidos isoladamente, perdem muito dessa ressonância conotativa”.

Em termos gerais, podemos situar a composição gonzaguiana no gênero lírico e idílico-bucólico, mas sabemos que ela apresenta elementos de gêneros fronteiriços, como a elegia e a poesia epigramática. ${ }^{95}$ Entre suas tópicas principais, podemos citar a tópica do convite amoroso, da brevidade da vida (o carpe diem), do locus amoenus, da perenidade da poesia, da formosura da amada e muitas outras. A elaboração do discurso gonzaguiano pode ser compreendida examinando-se as quatro partes da retórica, conforme $\mathrm{o}$ ensinamento de Aristóteles, sumarizado por Olivier Reboul (1998, p. 43-44): inventio ou invenção, a escolha dos conteúdos do discurso; dispositio ou disposição, organização dos

\footnotetext{
94 A expressão é de Antônio Candido: "esses movimentos do poema penetram no subconsciente do leitor devido a uma espécie de sedimentação dos modos e tempos verbais, que primeiro nos puxam para o passado, depois nos atiram para o futuro. $\mathrm{O}$ argumento se torna assim experiência incrustada em nossa sensibilidade (...)" . (grifos nossos). In: CANDIDO, 1985, p. 26.

95 A questão do gênero é matéria bastante complexa, sobre a qual não vamos nos aprofundar. Segundo João Angelo Oliva Neto, "a questão começa nos antigos, mas passa por autores posteriores, como os italianos. Quanto aos antigos, o poema [de Gonzaga] se relaciona com vários gêneros confins. Em geral a confinidade se dá por causa da matéria amorosa. Há um gênero que domina, do ponto de vista da elocução, da métrica, que é o gênero lírico ("lira" está como se fosse "ode", que é uma peça, uma unidade do gênero lírico). Assim, a moldura maior é lírica, sobretudo por causa da polimetria (o gênero da lírica é polimétrico). Toda elegia, por sua vez, tem apenas um metro, o dístico, e do ponto de vista da invenção pode corresponder a variados temas. Ou seja, em Tomás Antônio Gonzaga, a matéria ou invenção é bucólica e também pastoril, mas a maneira de dizer - a elocução e a disposição - é lírica. (Informação fornecida durante arguição oral, São Paulo, em 18/12/2020.)
} 
conteúdos num todo estruturado e elocutio ou elocução, a expressão adequada dos conteúdos (para fins de nossa análise, deixamos de lado a quarta parte, a pronuntiatio). A inventio em Marília de Dirceu assenta na escolha do assunto ou tema - o amor, o que inscreve o poema no gênero lírico. Trata-se de cantar exclusivamente a amada Marília e sua formosura. Para cantar Marília, no entanto, o poeta recorre a tópoi e temas da poesia pastoral, inscritos na longa tradição do gênero bucólico. Mas não se trata apenas de cantar Marília e sua formosura ("uma beleza em que ponha o seu cuidado"); trata-se de emparelhar dois pastores: Dirceu e Marília, enunciador e destinatária. Ao afeto da pastora corresponde o éthos de seu cantor. Seria oportuno lembrar que o discurso de Marília de Dirceu pode ser considerado epidítico, pois nele se louvam os atributos da pastora, ou seja, sua formosura e gentileza. Ao considerar os modos do discurso, Aristóteles designou como epidíticos os discursos que têm como matéria o elogio e a censura, a virtude e o vício. São aqueles em que "o tempo principal é o presente, visto que todos louvam ou censuram eventos atuais, embora muitas vezes também argumentem evocando o passado e conjecturando sobre o futuro" (ARISTÓTELES, 1358b, Retórica, p. 22). A "rusticidade fingida" da poesia bucólica de Marília de Dirceu, por sua vez, inscreve-se numa longa tradição poética. Segundo Alexandre Hasegawa, ${ }^{96}$ as origens do gênero bucólico remontam ao próprio Homero, que cantou os pastores conduzindo seus rebanhos ao som da siringe, em sua Ilíada (XVIII, v. 520-529). A partir daí, o gênero firmou-se com a contribuição de Teócrito, em seus Idílios, de Moscho e Bion. As Éclogas de Virgílio, no século I a.C., marcaram a consolidação do gênero, que alcançou seu nível mais elevado. Nas dez bucólicas que formam o poema virgiliano, os pastores apresentam-se como cantores, poetas e músicos; o cenário pastoril (o locus amoenus) constitui-se plenamente e vários dos principais topoi já estão estabelecidos, como o carpe diem, o fugere urbem e tantos outros. A oposição ente "avena" e "tuba" representa, alegoricamente, a diferença entre o gênero bucólico e épico, e é uma tópica retomada graciosamente por Gonzaga, ao solicitar às musas um instrumento adequado ao seu cantar:

Abaixa um pouco o tom, ó Musa, Dirceu não pode tanto. ${ }^{97}$

\footnotetext{
96 HASEGAWA, Alexandre Pinheiro. Os limites do gênero bucólico em Vergílio: um estudo das éclogas dramáticas. São Paulo: Humanitas, 2011, p. 13.

${ }_{97}$ É interessante notar, no entanto, que em Gonzaga é recorrente a presença de deuses próprios da poesia épica, como Jove, Juno, Marte, Vênus, enquanto é escassa a presença dos deuses menores que caracterizam a poesia bucólica (ninfas, faunos, sátiros, etc.).
} 
Observamos como o modo próprio da poesia bucólica ou pastoral é a dicção humilis. ${ }^{98}$ A Rota Virgilli, ${ }^{99}$ elaborada na Parisiana Poetria pelo gramático medieval João de Garlândia, classifica as Bucólicas de Virgílio como pertencente ao estilo humilde. Os poemas de matéria pastoral são aqueles de tênue elocução, tanto pela qualidade do assunto quanto das personagens. Podem-se atribuir esses cantos rústicos ao pastor-poeta Dáfnis, e mesmo ao deus Apolo (Febo) que se tornou pastor de gado após ser expulso do Olimpo. Embora diversas passagens argumentativas também façam parte deste discurso, a apóstrofe lírica pode ser tomada como procedimento linguístico e retórico que o sustenta.

\subsection{O nome de Marília}

Sem pretender, evidentemente, traçar uma genealogia exaustiva do nome de Marília, é possível delinear dentro da tradição do gênero lírico de matéria bucólica-pastoral a formulação de Marília como um protótipo de pastora. A mais antiga referência ao nome $^{100}$ Marília encontra-se em Teócrito (c.310 a.C. - 250 a.C.), considerado o pai da poesia bucólica. No Idílio III do poeta de Siracusa, o nome da pastora $(A \mu \alpha \rho v \lambda \lambda \iota \delta \alpha$, em grego) figura já no primeiro verso. A persona poética pede ao cabreiro Títiro que leve suas cabritas ao pasto e põe-se a cantar Amarílis.

Seresta farei a Amarílis: no entanto, as minhas cabritas pastam lá pelo monte, e Títiro é quem as conduz.

Títiro, ó meu bem amado, pasta as minhas cabritas,

E leva-as pra junto da fonte, Títiro: e aquele macho

- o líbio, o fulvinho - cuida que não te dê uma chifrada. ${ }^{101} 5$

A seguir, no verso 6 desta mesma écloga, o nome da pastora aparece no vocativo acompanhado de seu epíteto ("graciosa").

\footnotetext{
${ }^{98}$ Ao ressaltar a importância de estabelecer o genus dicendi para ler os poetas, Alexandre Hasegawa demonstra como o gênero bucólico é considerado humilis, ou baixo, chão, por todos os gramáticos e retores que se debruçaram sobre o tema, entre eles os gramáticos latinos Probo, Donato, Sérvio e Filargílio, que fizeram a descrição do gênero bucólico. Cf: HAGESAWA, 2011, p. 34 e sgs.

${ }^{99}$ In: GARLAND, John of. The Parisiana Poetria, Edited with introduction, translation and notes by Traugott Lawler. New Haven and London: Yale University Press 1974, p. 40-41.

${ }^{100}$ É possível que Marília seja um parônimo, um nome inventado por semelhança, e não derivado direto de Amarílis, uma vez que não se tem segurança sobre a origem etimológica do nome Marília.

${ }^{101}$ Utilizaremos para os Idílios de Teócrito a tradução de Érico Nogueira. In: Verdade, contenda e poesia nos Idílios de Teócrito. São Paulo: Humanitas, 2012.
} 
Graciosa Amarilis, por que, debruçando-te nesta caverna, não me chamas mais, a mim, teu benzinho? Odeias-me? Acaso, de perto, pareço ter narigão adunco, ninfa, e barbicha de bode? Acabas levando-me à forca. Olha, trago para ti dez maçãs, colhi-as de lá donde mandaste colher, e amanhã te trarei outras mais.

Amarílis também é referida no verso 22 deste mesmo idílio, em que o pastor-poeta lhe trança uma coroa de flores:

Esta coroa me fazes desfiar em fiozinhos agora, a qual, Amarílis amada, de hera que é, te reservo, trançada de aipo oloroso mais botõezinhos de rosa.

Note-se que o nome é acompanhado de seus epítetos ("graciosa Amarílis": “Amarílis amada”), como fará vinte séculos depois Tomás Antônio Gonzaga em suas liras. No Idílio IV, Amarílis também é citada nos versos 36 e 38. Trata-se de um diálogo entre Bato e Córidon. Bato lamenta que o pastor Córidon não toque mais a siringe, ao que Córidon protesta, afirmando que um músico é capaz de cantar muitos temas.

Não, pelas Ninfas, não mesmo; porquanto, partindo pra Pisa, deixou-a para mim de presente, e eu, bem ou mal, sou músico, 30 Canto o elogio de Crotona - "Que bela cidade é Zacinto..." -, e do Lacínio oriental, onde Égon, o tal pugilista, embora só, deglutiu oitenta empadas inteiras; pra onde um touro, erguendo-o pelos cascos, do monte trouxe e o deu a Amarilis: então as outras mulheres alto gritaram, porém o vaqueiro morreu de rir.

Na sequência, Bato invoca Amarílis, a quem não pode esquecer, e lamenta seu destino com a morte da pastora.

Ó graciosa Amarílis, só de ti, mesmo morta, Não vou me esquecer: como as cabras tão caras a mim, tu te foste. 40 Ai, como é duro, decerto, o fado que a mim me tocou. 
Alguns elementos estilísticos da obra inaugural como a invocação à pastora e seu nome acompanhado por epítetos referidos à sua formosura podem ser reconhecidos em Marília de Dirceu. A persona poética do pastor-cantor dirige-se a ela. Também o cenário pastoral está plenamente configurado: campos, fontes, regatos, árvores e flores, em meio aos quais os pastores nas pausas de seus afazeres se divertem em porfias de canto cantando suas amadas. Para tal, utilizam tópicas sobre como tecer uma coroa de flores ou oferecer presentes a Amarílis.

No mundo latino, a referência mais conhecida a Marília é a personagem Amarílis (Amaryllis, no original latino) que comparece à primeira estrofe da Bucólica I de Virgílio. Trata-se de um poema dramático que encena o diálogo entre dois pastores, Títiro e Melibeu. Melibeu dirige-se ao pastor Títiro, que canta sob a sombra de uma faia.

Ó Títiro, deitado à sombra de uma vasta faia, aplicas-te à silvestre musa com uma frauta leve; nós o solo da pátria e os doces campos nós deixamos; nós a pátria fugimos: tu, na sombra vagaroso, fazes a selva ecoar o nome de Amarílis bela. ${ }^{102}$

Nota-se que o epíteto "formosam" associado à Marília ("formosam Amarilis") aparece já nesta passagem, traduzida como "Amarílis bela". Títiro, o pastor que canta Marília, está descansando embaixo de uma faia e toca uma "frauta leve". Tanto a árvore que simboliza a poesia pastoral, bem como o instrumento do pastor se fazem presentes. Em Marília de Dirceu, o pastor convida Marília a descansar "à sombra deste cedro levantado" (lira I, 19).

Enquanto pasta alegre o manso gado,

Minha bela Marília, nos sentemos

À sombra deste cedro levantado.

Um pouco meditemos

$\mathrm{Na}$ regular beleza,

Que em tudo quanto vive nos descobre

A sábia natureza.

Se a flauta, a siringe ${ }^{103}$ e a lira tanto servem como instrumentos do pastor, podendo representar o próprio gênero bucólico, em Gonzaga temos a sanfoninha, instrumento

\footnotetext{
${ }^{102}$ Utilizaremos para as Bucólicas de Virgílio a tradução de Péricles Eugênio da Silva Ramos. In: VIRGíLIO, Bucólicas. Tradução e notas de Péricles E. S. Ramos. Introdução de Nogueira Moutinho. São Paulo: Melhoramentos/Ed. Universidade de Brasília, 1982.
} 
mencionado na lira de abertura ("Com tal destreza toco a sanfoninha,/ Que inveja até me tem o próprio Alceste", I,1, vv. 15 e 16). Qual a origem poética da sanfoninha que Dirceu toca com destreza? Algumas hipóteses sobre o sentido dos vocábulos "sanfona" ou "sanfoninha" em matéria poética pastoral podem ser feitas. O Vocabulário portuguez e latino de Rafael Bluteau registra que "sanfonha” significa "frauta pastoril”.

Derivase do italiano Sampogna (que no dito idioma se pronuncia, como se estivera escrito, Samponha.) (BLUTEAU, 1756, p. 469).

O dicionarista dá-lhe também o significado de "fístula pastoral". ${ }^{104}$ Já o termo “sanfonina” tem a seguinte acepção:

SANFONINA, ou çanfonina. Querem que se derive de Sinfonia, que não só quer dizer união de vozes, [...] mas também é instrumento musical [..]. Sanfonina pois é instrumento commum nos cegos, que o tãgem ao povo para ganhar a vida. Tem no ventre quatro cordas, duas das quaes se pódem reduzir a unisono, \& a oytava, as outras duas estendidas por fóra, fazem hum perpetuo monocordo com toda a variedade de sons, por meyo de huñas teclas, \& em cima huña roda de pao muyto lysa, que a maõ direyta move circularmente, $\&$ tocando a mão esquerda as teclas, faz hum som agradavel. (BLUTEAU, Id., ib.)

O dicionário contemporâneo traz a definição de "sanfona" como instrumento muito antigo, de cordas de tripa, que se tange por meio de uma manivela e que também é denominado sanfonha. ${ }^{105}$ Note-se que a acepção de "sanfonina" adotada por Bluteau se assemelha à nossa moderna "sanfona" ou até uma espécie de realejo. Para demonstrar seu uso no século XVI o erudito aponta versos de Luís de Camões, que empregou o termo na Écloga 6:

Ouvi da minha humilde Sanfonina

A harmonia, que vós já levantais

\footnotetext{
${ }^{103}$ A siringe é a flauta produzida com o colmo da cana; flauta de Pã. A lira é o símbolo. Hermes roubou uma vaca de Apolo e Zeus ordenou que a devolvesse. Hermes então começou a tocar a lira, que acabara de inventar. Em agradecimento, Apolo devolveu o animal a Hermes em troca da lira.

${ }^{104}$ Fístula. Do latim fistula-, "fístula, canal". 3. poético Flauta pastoril. In: Dicionário infopédia da língua portuguesa. Porto: Porto Editora, 2003-2019. Disponível em: https://www.infopedia.pt/dicionarios/linguaportuguesa/fístula. Acesso em: out. 2019.

${ }^{105}$ In Dicionário infopédia da lingua portuguesa [em linha]. Porto: Porto Editora, 2003-2019. Disponível em: https://www.infopedia.pt/dicionarios/lingua-portuguesa/sanfona. Acesso em: out. 2019.
} 
A "sanfona" também foi utilizada pelo poeta napolitano Sannazzaro (1458-1530), em sua obra-mestra Arcadia. Rita Marnoto observou essa ocorrência na cena final do romance pastoril.

Sannazaro deixou a flauta pastoril naqueles montes. A sua melodia, porém, ficou gravada para todo o sempre na memória dos seus leitores. Muitos foram os poetas que partiram em busca dessa sanfona, e que experimentam as suas sonoridades - Tasso, Giraldi Cinzio, Spenser, Sidney, Belleau, Ronsard, Jorge de Montemor, Gil Polo, Gálvez de Montalvo, Cervantes, Sá de Miranda, Antônio Ferreira, Camões, ou Frei Álvares do Oriente, entre muitos outros. O ciclo prolongou-se a partir das páginas da Arcadia - mas para além delas. ${ }^{106}$

O significado dos vocábulos relacionados aos instrumentos pastoris também é discutido por Georges Cirot. ${ }^{107} \mathrm{O}$ estudioso discorre sobre o uso do termo "zanfoña" e "zampoña", e outros vocábulos que se referem à música na poesia bucólica, referindo a dificuldade de figurar os instrumentos citados pelos poetas bucólicos. Se a sanfona pode ser tomada por "flauta pastoril" na lira I,1, é pertinente lembrar que na lira II,1 sua acepção está mais próxima daquela de "sanfona".

Retomemos a primeira Bucólica de Virgílio. No verso 30, Amarílis é referida novamente:

A liberdade que me viu ocioso, tarde embora, Quando, ao fazer a barba, esta caía já mais branca; Viu-me contudo e me chegou depois de longo tempo, Ao tempo de Amarílis e depois de Galateia.

No verso 36, Amarílis é mencionada como vocativo:

\footnotetext{
${ }^{106}$ In: MARNOTO, Rita. A Arcadia de Sannazaro e o bucolismo. Pref. de Aníbal Pinto de Castro. Coimbra: Gabinete de Publicações da FLUC, 1996, p.141. No prefácio ao estudo de Marnoto, o estudioso Aníbal P. refere que o estudo propicia "o melhor conhecimento de um dos mais ricos filões de produção de toda a Literatura Portuguesa, desde o primeiro quartel do século XVI, quando Sá de Miranda, lá nos lazeres da sua dourada mediania horaciana fruida em Terras de Basto, lia com o amigo Antônio Pereira, de alcunha o Marramaque, as páginas de peregrina beleza em que se narravam e cantavam as ditas e desditas dos 'pastores italianos/ do bom velho Sannazaro', ao mesmo tempo que se deliciavam com os amores de Orlando, ficcionados nas páginas das grandes epopeias ferraresas de Ariosto e de Boiardo, com a sublimação da vivência amorosa pela via neoplatonista discutida nos diálogos travados pelas damas galantes e pelos gentis homens reunidos por Bembo no Castelo de Asolo, ou com as penas de amor que, aqui mais perto, desferiam das suas sanfonas os zagais de Juan Boscán e Garcilaso de La Vega”. Id., ib., p.7. (grifos nossos).

${ }^{107}$ CIROT, Georges. Zanfoña et Zampoña. In: Bulletin Hispanique, t. 43, n. 2, 1941. p. 152-161.
} 
Por que tristonha os deuses invocavas, Amarílis,

e para quem nas árvores deixavas pender frutas?

Na Bucólica II, Marília é apresentada no verso 14, no momento em que Córidon, o pastor, reflete sobre sua paixão não correspondida por Aléxis.

Não seria melhor sofrer as iras aflitivas e o soberbo desprezo de Amarílis? ou Menalcas, moreno embora seja ele, quando tu és alvo?

Nos versos 51 e 52 da Bucólica II, o nome de Amarílis é novamente invocado, como "Amarílis minha":

E frutos brancos, de lanugem branda, eu colherei, e essas castanhas que a Amarílis minha tanto amava;

O pastor-poeta, por sua vez, descreve a si mesmo nos versos 20 a 27, da Bucólica II, de Virgílio, com a mesma tópica que utilizará o eu poético de Marília de Dirceu. A propriedade, o rebanho, o leite, as proezas no canto e a bela aparência testemunhada pela imagem espelhada na água são usados como argumentos para atrair o afeto de Aléxis, no primeiro, e de Marília, no segundo. Em Virgílio:

Tu me desprezas, nem indagas quem sou eu, Aléxis, quantos rebanhos tenho, quanto leite cor de neve; erram nos montes da Sicília as minhas mil cordeiras; não me falta no estio leite fresco, nem no inverno; eu canto o que cantava habitualmente Anfião de Dirce no ático Aracinto, se chamava os seus rebanhos. E não sou tão feio assim: vi-me na praia, há pouco tempo, 25 com o mar tranquilo sob o vento: não receio Dáfnis, sendo tu mesmo o juiz, se não enganam as imagens.

\section{E em Tomás Antônio Gonzaga.}

Tenho próprio casal e nele assisto;

Dá me vinho, legume, fruta, azeite; Das brancas ovelhinhas tiro o leite, E mais as finas lãs de que me visto.

Eu vi o meu semblante numa fonte: 
Dos anos inda não está cortado;

Os Pastores, que habitam este monte,

Respeitam o poder do meu cajado.

Com tal destreza toco a sanfoninha,

Que inveja até me tem o próprio Alceste:

Ao som dela concerto a voz celeste

Nem canto letra que não seja minha.

Lira I, 1

O tradutor e comentador Péricles Eugênio da Silva Ramos lembra que a descrição nos versos das Bucólicas II de Virgílio remonta a Teócrito:

[...] os comentaristas, em linhas anteriores, citam versos de Teócrito, não muito próximos, como precedente. Mas aqui o paralelo é mais estreito. 'Eu sou rico, eu canto bem, eu não sou tão feio'; os dois desdobramentos de acordo com Teócrito, XI, 34-40, e o terceiro, segundo o mesmo autor, VI, 34-38, todos relativos a Polifemo, o ciclope apaixonado por uma nereida. ${ }^{108}$

O nome "Dirceu” também teria sido extraído da segunda Bucólica de Virgílio.

eu canto o que cantava habitualmente Anfião de Dirce no ático Aracinto, se chamava os seus rebanhos. ${ }^{109}$

Outro poeta latino, Ovídio, em sua $A$ arte de amar, ${ }^{110}$ cita Amarílis em duas passagens. Na primeira, ao revelar os presentes que se deve dar às amantes, lembra que Amarílis apreciava uvas e castanhas, sugerindo o valor da humildade.

Não aconselho que dês presentes caros à tua amante;

Dá os modestos, mas oportunos,

e sejas hábil na simplicidade.

Quando os campos estiverem fartos, quando os ramos se inclinam com o peso, Que um garoto leve frutos em um cesto;

Poderás dizer que te foram enviados do campo,

se quiseres, ainda que os tenhas comprado na via Sacra;

Que ele leve as uvas, as castanhas que Amarilis amava

(Mas que ela agora já não ama); ${ }^{111}$

\footnotetext{
${ }^{108}$ Op. cit., p. 51.

109 No original latino: Canto, quae solitus, si quando armenta uocabat,/ Amphion Dircaeus in Actaeo Aracyntho. (Virgílio, op. cit., p. 46). Por analogia, "Dircaeus" teria se tornado "Dirceu", como já apontara Alberto Faia em nota à sua edição de Marília de Dirceu.

110 Tradução utilizada: SILVEIRA, Maria da Conceição. A comparação semântica como estratégia discursiva na Ars Amatoria, de Ovídio (Mestrado). Orientador: Carlos Antônio Kalil Tannus. Rio de Janeiro, Faculdade de Letras da UFRJ, 2003. 164 fls.

${ }^{111}$ Ovídio, Arte de amar, vv. 261-268.
} 
Num outro momento, Ovídio descreve as cores com que se adornam as mulheres:

Aquela imita o açafrão (a deusa do orvalho

Cobre-se com um manto de açafrão

Quando atrela seus cavalos luminosos);

Esta, a murta de Pafos, aquela outra as ametistas cor de púrpura,

As alvas rosas ou o grou da Trácia.

Não faltam tuas castanhas, Amarílis, nem as amêndoas,

E a cera que deu seu nome a tecidos. ${ }^{12}$

Verificamos que na poesia bucólica o nome de Marília pertence a uma tópica de longa duração, revisitada e apropriada por autores de Teócrito a Bocage. No Renascimento, Marília foi personagem de vários poetas, não apenas portugueses. Edmund Spencer (1552-1599) compôs o longo poema Colin Clouts Come Home Again. reunindo pastoras e pastores em sua Arcádia imaginada. Marília está presente em duas passagens importantes.

Amyntas quite is gone, and lies full low, Hauing his Amaryllis left to mone.

Helpe, $\mathrm{O}$ ye shepheards helpe ye all in this, Helpe Amaryllis this her losse to mourne: Her losse is yours, your losse Amyntas is, Amyntas floure of Shepheards pride forlorne:

Nesta outra passagem, Amaryllis é comparada a Phyllis e Charyllis:

Ne lesse paiseworthie are the sister three,

The honor of the noble familie:

Of which I meanest boast my selfe to be, And most that vnto them I am so nie.

Phyllis, Charyllis, and sweet Amaryllis:

(...)

But Amaryllis, whether fortunate,

Or else vnfortunate may I aread.

That freed is from Cupids yoke by fate,

${ }^{112} I d$., ib., vv. 178 a 184. 
Na Península Ibérica, Fernando Herrera (1534-1597) dedicou uma écloga a Amarilis em que os pastores lamentam sua morte. Nas éclogas e sonetos portugueses quinhentistas, a presença de pastoras cujo nome é Marília também é abundante. ${ }^{113} \mathrm{Na}$ écloga V de Diogo Bernardes, o enunciador dirige-se à pastora Marília, instando-a para que não se esqueça de Silvio. Já aqui ocorre o apelo exortativo, em que o poeta se dirige diretamente à amada:

Assi Marília minha, não t'esqueças De Sílvio, o mesmo Sílvio me dizia, Que nunca negue cousa que me peças.

Por ti entre serpentes andaria seguro, por ti ledo, \& sem temor

${ }^{113}$ A pesquisadora Ana Filipa Gomes Ferreira chama atenção para a voz feminina em algumas das éclogas portuguesas, mostrando como várias éclogas seguem o modelo virgiliano da segunda Bucólica. 
Per antre fogo, \& ferro passaria.

Criou Amor em mim um novo Amor,

Um coração tão novo que sem ti

Sente, no mor descanso maior dor.

Naquele mesmo ponto em que te vi,

Fosse força d'Amor, fosse d'estrelas, [fl. 18r]

O gosto de mais ver logo perdi.

Muitas ovelhas tenho, \& as mais delas

Parem de cada parto dous cordeiros,

O leite também é dobrado nelas.

Tenho cem cabras mais, que dous rafeiros

Um malhado de negro, outro de branco

Nos vales guardam sempre, $\&$ nos outeiros.

Pois tanger, \& cantar, poucos em campo

Ousam entrar comigo, porque sabem

Que tais dous mestres tive, Alcipo, \& Franco

Inda que de gabar-me, me desgabem,

Gabo-me, porque saibas que não erras

Em querer que meus males já se acabem.

Viveremos aqui antr'estas serras

Contentes, quão contentes, sem enveja

D'outros, que têm mais gado n'outras terras. 16

Em Francisco de Quevedo (1580-1645), podemos apontar a graciosíssima écloga nomeada Amarilis.

\author{
Estaba Amarilis, \\ pastora soberbia, \\ guardando ganados \\ al pie de una sierra. \\ Sentada a la sombra \\ de una parda peña, \\ hacienda grinaldas \\ para su cabeza. \\ Cortaba las flores \\ que hallaba más cerca, \\ íbanse a sus manos \\ las que lejos eran. \\ Las que se ceñia \\ Siempre estaban frescas, \\ y las que dejaba \\ de endivia se secan. \\ El sol, que la mira, \\ $\tan$ hermosa, piensa
}


que tiene dos caras, o que el sol es ella.

Su ganado ufano anda por las cuestas con tan bello dueño, sin temor a las fieras.

Já no século XVIII, o poeta lusitano Bocage produziu uma profusão de sonetos que traziam o nome da pastora Marília:

Assim parte, assim voa; eis que vê posto

No colo de Marília o deus alado,

No colo aonde tem mimoso encosto: ${ }^{114}$

(BOCAGE, p. 23)

Outro exemplo em que o retrato de Marília está guarnecido por uma "chusma de Amorinhos", para usar uma expressão de Gonzaga:

Marília, nos teus olhos buliçosos

Os Amores gentis seu facho acendem;

A teus lábios voando os ares fendem

Terníssimos desejos sequiosos.

(BOCAGE, p. 24)

Ou ainda, a sugerir que a formosura de Marília ultrapassa os atributos da própria deusa da beleza:

Oh perfeições! Ó dons encantadores!

De quem sois?... Sois de Vênus? - É mentira;

Sois de Marília, sois de meus amores.

(BOCAGE, p. 25)

Ou ainda,

Que a mim, para que viva satisfeito,

Me basta possuir teu doce agrado,

Ter lugar, Marília, no teu peito.

(BOCAGE, p. 32)

Como último exemplo, podemos ler o soneto em que o eu poético compartilha com Marília a celebração do locus amoenus, com apelo aos sentidos e emprego da sinestesia:

114 BOCAGE, Manuel Maria Barbosa Du. Soneto e outros poemas. São Paulo: FTD, 1994 (Grandes Leituras). 
Olha, Marília, as flautas dos pastores, Que bem que soam, como estão cadentes! Olha o Tejo a sorrir-se! Olha: não sentes Os Zéfiros brincar por entre as flores?

Vê como ali, beijando-se, os Amores Incitam nossos ósculos ardentes! Ei-las de planta em planta as inocentes, As vagas borboletas de mil cores!

Naquele arbusto o rouxinol suspira; Ora nas folhas a abelhinha, para, Ora nos ares, sussurrando, gira.

Que alegre campo! Que manhã tão clara! Mas ah!, tudo o que vês, se eu não te vira, Mais tristeza que a noite me causara.

(BOCAGE, p. 34)

Observe que, além de Marília, a persona poética dos sonetos de Bocage canta e declara seu amor para uma profusão de pastoras: Marina, Nise, Acidália, Elmira, Anarda, Ritália, para citar apenas algumas, como era comum na tradição bucólica. Os nomes pastoris eram convencionais, e muitas vezes alternavam-se para formar novos casais. ${ }^{115}$ Como observa Ferreira, a estima entre pastores e pastoras não configura casais consolidados, e os nomes pastoris podem ser intercambiáveis. Esse procedimento, observado em Diogo Bernardes, pode bem ser estendido à poesia bucólica de modo geral; mas em Marília de Dirceu ecoam os "casais de sonho" da tradição poética, a começar pelas elegias eróticas latinas. Na elegia erótica romana, como ensina o estudioso Paul Veyne:

Dois ou três decênios antes do começo da nossa era, jovens poetas romanos, Propércio, Tibulo e, na geração seguinte, Ovídio, decidiram-se a cantar na primeira pessoa, com seu verdadeiro nome, episódios amorosos e relacionar esses diversos episódios a uma só e mesma heroína, designada por um nome mitológico; a imaginação dos leitores povoou-se assim de casais de sonho: Propércio e sua Cíntia, Tibulo e sua Délia, Ovídio e sua Corina. (...) esses versos de amor eram feitos em

\footnotetext{
${ }^{115}$ A pesquisadora Ana Filipa Gomes Ferreira estuda sob essa perspectiva as éclogas IV e V de Diogo Bernardes e a écloga II de Luís de Camões, citando alguns exemplos: "Na Écloga IV, Fílis ama Córidon, que ama Galateia; na Écloga XI, Galateia é amada de Palemo. Marília relembra Ś́lvio (Écloga V); noutro poema, é amada por Alcido (Écloga III). Outro ou o mesmo Alcido chama Sílvia (Écloga XIV), enquanto Meliso chama Lília (Écloga XIII)". In: FERREIRA, Ana Filipa Gomes. Voz feminina nas éclogas de Diogo Bernardes e Luís de Camões, Centro de Estudos Clássicos, s/d.
} 
ritmo elegíaco (...); estamos falando da elegia erótica romana. ${ }^{116}$ (Grifo nosso)

O enunciador em Marília de Dirceu menciona pares de musas e poetas que as cantaram: Laura de Petrarca (1304-1374) e Clorinda de Tasso (1544-1595). Tais menções nos remetem à tradição da lírica amorosa praticada na península itálica dos séculos XIV a XVI, aos quais se poderia acrescentar Beatriz de Dante (1265-1321). A exclusividade de Marília como pastora a quem se destinam seus versos será fator decisivo na estratégia compositiva de Marília de Dirceu.

Para além do campo das letras, podemos atestar a disseminação do nome Marília na esfera da cultura e da ciência. O naturalista Lineu, em fins do século XVIII, designa como Amaryllis uma espécie de flor ou espécie de inflorescência. ${ }^{117}$ Os dicionários etimológicos informam que a origem de Marília encontra-se no grego antigo A $\mu \alpha \rho \nu \lambda \lambda i ́ \varsigma$ (Amaryllis), que estaria ligado ao verbo à $\mu \alpha \rho v ́ \sigma \sigma \omega$ (amarússō, “cintilar”, “brilhar”) e, por extensão, "resplandecente", "brilhante". 118

\subsection{O privilégio da interlocução}

O papel mais evidente de Marília no discurso de Gonzaga é o de destinatária. Trata-se de uma situação discursiva que envolve uma persona poética, que é um pastor, e um $t u$, uma pastora (Marília). Como destinatária do poema, representada pela segunda pessoa do discurso, Marília assume o lugar do leitor/ouvinte e/ou do auditório que o orador deve persuadir. Segundo a análise do discurso, este procedimento linguístico é chamado de debreagem actancial e se refere à projeção, no enunciado, dos actantes da enunciação eu

\footnotetext{
116 VEYNE. Paul. A elegia erótica romana: o amor, a poesia e o Ocidente. Trad. de Milton Meira do Nascimento e Maria das Graças de Souza Nascimento. São Paulo: Brasiliense, 1985. p. 9.

${ }^{117}$ Criado por Lineu em 1753, desde a sua primeira descrição o gênero incluiu numerosas espécies que posteriormente foram transferidas para outros géneros. Permaneceu um gênero monotípico durante a maior parte do século XX, integrando apenas a espécie Amaryllis belladonna. Em 1998, a botânica sulafricana Dierdre Snijman descubriu e descreveu uma segunda espécie, a Amaryllis paradisicola. Veja

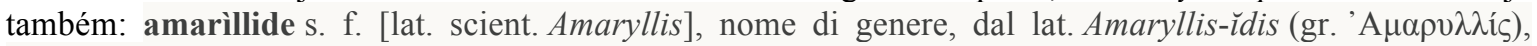
nome proprio di pastorelle, frequente nella poesia bucolica]. - Nome di varie piante appartenenti a diversi generi della famiglia amarillidacee, e in partic. della specie Amaryllis belladonna: pianta bulbosa coltivata per i fiori, disposti in falsa ombrella all'apice del lungo scapo. Istituto Treccanni.

${ }^{118}$ Amaryllis (n.) Autumn-flowering bulb, 1794, adopted by Linnaeus from Latin, from Greek Amaryllis, typical name of a country girl or shepherdess (in Theocritus, Virgil, Ovid, etc.), from amaryssein "to sparkle, twinkle, glance," as the eye, a word which according to Beekes "may well be of Pre-Greek origin." Disponível em: https://www.etymonline.com/word/amaryllis. Acesso em: ago. 2019. Cf. RUEDAS DE LA SERNA, Jorge Antonio. Arcádia: tradição e mudança. São Paulo: Edusp, 1995.
} 
(que fala) e $t u$ (para quem se fala). ${ }^{119}$ Afinal,

A enunciação é o ato de produção do discurso, é uma instância pressuposta pelo enunciado (produto da enunciação). Ao realizar-se, ela deixa marcas no discurso que constrói. (FIORIN, 2018, p. 55)

A fim de produzir o docere, movere e delectare, conforme o ensinamento de Cícero, ${ }^{120}$ o procedimento linguístico próprio deste discurso é a apóstrofe lírica, em que o interlocutor é interpelado continuamente. A apóstrofe pode ser definida como uma

\begin{abstract}
interpelação, geralmente exclamativa, a um interlocutor em particular, vivo ou morto, presente ou ausente, real ou fantástico. Muito próxima da ênfase, distingue-se desta pela necessidade de um interlocutor sem o qual não tem significado. Também não deve ser confundida com a invocação, embora a possa integrar, porque é mais breve. O destinatário da apóstrofe pode aparecer no princípio ou no fim da frase, dependendo da ênfase procurada, não sendo obrigatório que o discurso seja interrompido, como erroneamente algumas definições preveem para esta figura. A situação mais comum é a que remete a apóstrofe para um destinatário ausente que se invoca diretamente. Apóstrofe clássica é a invocação das Tágides n'Os Lusíadas: "E vós, Tágides minhas, pois criado/ Tendes em mim um novo engenho ardente" (I, 4). A suposta entidade ausente ("Tágides") é convocada para uma situação que a traz para a presença do Poeta. (CEIA, 2019)
\end{abstract}

A apóstrofe pode suscitar um efeito de aproximação entre $e u$ e $t u$. Tal procedimento retórico tensiona a relação entre enunciador e destinatário, e seu corolário é um discurso sempre atualizado, no tempo presente. ${ }^{121}$ As pessoas que constituem o discurso gonzaguiano são os interlocutores Dirceu e Marília. O espaço em que esse discurso se dá é,

\footnotetext{
119 Seguindo a orientação da linguística greimasiana, Fiorin afirma que “(...) é preciso distinguir duas instâncias: o eu pressuposto e o eu projetado no interior do enunciado. Teoricamente, essas duas instâncias não se confundem: a do $e u$ pressuposto é a do enunciador e a do eu projetado no interior do enunciado é a do narrador. Como a cada $e u$ corresponde um $t u$, há um $t u$ pressuposto, o enunciatário, e um $t u$ projetado no interior do enunciado, o narratário. Além disso, o narrador pode dar a palavra a personagens, que falam em discurso direto, instaurando-se então como $e u$ e estabelecendo aquele com quem falam como $t u$. Nesse nível, temos o interlocutor e o interlocutário" (FIORIN, 2018, p. 56). Neste trabalho, deixamos de lado a nomenclatura técnica, para utilizar os termos $e u$ e $t u$, enunciador/destinatária (para falar do $e u$ que preside a enunciação e daquela a quem o enunciador se dirige) e interlocutor/interlocutora (para caracterizar os actantes do enunciado).

120 "O discurso persuasivo, aquele destinado a agir sobre os outros através do logos (palavra e razão), envolve a disposição que os ouvintes conferem aos que falam (éthos) e a reação a ser desencadeada nos que ouvem (pathos). Estes são os três elementos que irão figurar em todas as definições posteriores e que compreendem o instruir (docere), comover (movere) e o agradar (delectare)". In: MOSCA, 2001, p. 22.

${ }^{121}$ Segundo analisa Fiorin, "O $e u$ realiza o ato de dizer num determinado tempo e num determinado espaço. Aqui é o espaço do $e u$, a partir do qual todo os espaços são ordenados (aí, lá); agora é o momento em que o eu toma a palavra e, a partir dele, toda a temporalidade linguística é organizada. A enunciação é a instância que povoa o enunciado de pessoas, de tempos e espaços (...).
} 
preferencialmente, o locus amoeunus bucólico, mas pode comportar também outros cenários (o Templo da Fortuna, por exemplo), e em especial a masmorra, cenário da segunda parte da obra. O discurso do pastor está sempre no presente (tempo próprio do discurso epidítico), pois o enunciador se dirige à Marília, investida do papel de interlocutora, e com ela compartilha (no presente) os desejos projetados para os tempos futuros, as esperanças da felicidade amorosa, a vida de sonhos que teriam juntos. Ou então volta-se ao passado para compará-lo ao presente ou para evocar um bem perdido. Para investigar com mais propriedade este mecanismo, recorremos à noção de "dêixis" de Sérsi Bardara: ${ }^{122}$

\begin{abstract}
De forma genérica, o termo "dêixis", do qual deriva o adjetivo "dêitico", é empregado para designar a função que os pronomes pessoais e demonstrativos, as formas gramaticais que indicam tempo, inúmeras palavras e uma variedade de outras formas linguísticas desempenham ao fazer eferência à situação de produção dos gêneros textuais, sejam estes nas modalidades oral ou escrita.

Instrumentos linguísticos responsáveis pela coesão, os dêiticos (...), além de assegurarem uma ligação entre os elementos que ocorrem na superfície textual, fazem referência à situação de enunciação, ou seja, ao contexto extralinguístico, constitutivo do sentido dos enunciados. (BARDARA, 2011, p. 1)
\end{abstract}

Observe-se a lira I,5, em que o enunciador trata da transformação do locus amoenus, aproximando-se da tópica do ubi sunt?. ${ }^{123} \mathrm{O}$ eu poético lamenta a dissolução trazida pelo tempo. Na primeira estrofe, utiliza os verbos no pretérito imperfeito, descrevendo a paisagem bucólica e, por consequência, a vida feliz de que desfrutava no passado. O lugar de onde o eu poético fala, no entanto, é essa mesma paisagem, que

\footnotetext{
${ }^{122}$ BARDARA, Sérsi. A função dos dêiticos na estruturação do texto. Entremeios: revista de estudos do discurso. v. 3, n. 1, Faculdade de Filosofia, Letras e Ciências Humanas. Pontifícia Universidade Católica do Rio de Janeiro. Rio de Janeiro, jun. 2011.

${ }^{123}$ UBI SUNT MOTIF (Latin, "Where are....?"): A literary motif dealing with the transience of life. The name comes from a longer Latin phrase, "Ubi sunt qui ante nos fuerent?" [Where are those who were before us?], a phrase that begins several medieval poems in Latin. The phrase evokes the transience of life, youth, beauty, and human endeavor. It is a particularly common motif in the ballades. A particularly memorable example comes from medieval French, where Francois Villon repeatedly asks in "The Ballade of Dead Ladies," "Ou sont les neiges d'antan?" ["Where are the snows of yesteryear?"]. Many Anglo-Saxon poems such as "The Ruin" and "The Wanderer" also deal with this theme. Although the motif is similar to the Roman carpe diem motif in its emphasis on transitory existence, the medieval ubi sunt motif usually does not call on the reader to embrace this world's pleasures before the end comes, but instead grimly or sorrowfully urges the reader to prepare spiritually for the afterlife. Literary Terms and Definitions. Dr. Wheeler Website. Ubi sunt motif. 24.04. 2018.
} 
observa no presente. O chamado de Marília, no estribilho, basta para reconstituir o mundo perdido.
Acaso são estes
Os sítios formosos,
Aonde passava
Os anos gostosos?
São estes os prados
Aonde brincava,
Enquanto pastava
O manso rebanho,
Que Alceu me deixou?
São estes os sítios?
São estes; mas eu
O mesmo não sou.
Marília, tu chamas?
Espera, que eu vou.

(grifos nossos)

Na lira II, 9 o poeta se dedica a rememorar a vida feliz que tinha ao lado da amada:
A estas horas
Eu procurava
Os meus Amores;
Tinham-me inveja
Os mais Pastores.

A porta abria, Inda esfregando

Os olhos belos,

Sem flor, nem fita

Nos seus cabelos;

Ah! Que assim mesmo

Sem compostura,

É mais formosa

Que a estrela d'alva,

Que a fresca rosa!

$[\ldots]$

Desta maneira,

Nos castos peitos,

De dia em dia

A nossa chama

Mais se acendia.

A continuidade do passado feliz ao lado de Marília é reiterada. Na última estrofe, dá-se a inflexão que transporta e contrasta a bonomia do passado ao sofrimento do 
presente. É a interlocutora Marília, mais uma vez, quem testemunha a ruína do poeta e o recoloca no tempo presente.
Assim vivia;
Hoje em suspiros
O canto mudo:
Assim, Marília,
Se acaba tudo!

Nem todas as liras obedecem rigorosamente a essa estrutura discursiva. São vários os modos de proximidade entre a persona poética e Marília, e estes variam também em intensidade. Embora alguns críticos apontem a representação de Marília como estática e contemplativa, "sem voz", pode-se observar um grande esforço em trazê-la para perto de si, para dotá-la de vida, para atribuir-lhe estados e humores variados. Podem ser sentimentos de ciúme ou enfado, podem ser lamentos ou até mesmo sensações de horror. Como afirma Barbara Johnson, a apóstrofe lírica consiste numa "form of ventriloquism through which the speaker throws voice, life, and human form into the addressee, turning its silence into mute responsiveness." (JOHNSON, 1994, p. 216, apud Ceia, 2019).

O paradigma dessa aproximação entre a persona poética e Marília ocorre já na primeira lira de Marília de Dirceu, em que se figura certa ação da interlocutora, no gesto de olhar e sorrir:

Para viver feliz, Marília, basta

Que os olhos movas, e me dês um riso.

Na lira I, 2, o poeta compara Marília a Cupido.

Porém eu, Marília, nego

Que assim seja Amor; pois ele

Nem é moço, nem é cego,

Nem setas, nem asas tem.

Depois de pintar o retrato da pastora, narra uma sucessão de ações que teriam sido executadas por Marília. Aqui o poeta representa um jogo de olhares, atualizando uma tópica do desconcerto do sujeito recorrente em Camões, Botelho de Oliveira e outros poetas: 
Mal vi seu rosto perfeito

Dei logo um suspiro, e ele

Conheceu haver-me feito

Estrago no coração.

Punha em mim os olhos, quando

Entendia eu não olhava:

Vendo o que via, baixava

A modesta vista ao chão.

Mais adiante, um gracioso contraponto entre a ousadia do pastor e a timidez e modéstia da amada se evidencia.

Chamei-lhe um dia formoso:

Ele, ouvindo os seus louvores,

Com um gesto desdenhoso

Se sorriu, e não falou.

O enunciador persiste,

Pintei-lhe outra vez o estado,

Em que estava esta alma posta;

Não me deu também resposta,

Constrangeu-se, e suspirou.

Finalmente mostra-se ainda mais audaz, ao pegar a mão de Marília e tentar beijá-la; no entanto Marília se afasta, encabulada:

Conheço os sinais, e logo

Animado de esperança,

Busco dar um desafogo

Ao cansado coração.

Pego em teus dedos nevados,

E querendo dar-lhe um beijo,

Cobriu-se toda de pejo,

E fugiu-me com a mão.

Na lira I, 4, os sentimentos de Marília (de alegria ou de mágoa) são secundados pelos sentimentos de Dirceu.

Se estavas alegre,

Dirceu se alegrava;

Se estavas sentida,

Dirceu suspirava

À força da dor. 
Em I, 8, Marília se queixa de ter o coração roubado.

\author{
Marília, de que te queixas? \\ De que te roubou Dirceu \\ $\mathrm{O}$ sincero coração? \\ Não te deu também o seu? \\ E tu, Marília, primeiro \\ Não lhe lançaste o grilhão?
}

Em I, 6, os dotes morais de Marília que "valem imenso tesouro" são figurados por seus movimentos e gestos.
A minha Marília quanto
À natureza não deve!
Tem divino rosto,
E tem mãos de neve.
Se mostro na face o gosto,
Ri-se Marília contente;
Se canto, canta comigo,
E apenas triste me sente,
Limpa os olhos com as tranças
De fino cabelo louro.
A minha Marília vale,
Vale um imenso tesouro.

Seja na alegria ou na tristeza, pastor e pastora permanecem unidos. Já na

lira I, 17, Marília está aborrecida e chega a demonstrar raiva.
Minha Marília,
Tu enfadada?
Que mão ousada
Perturbar pode
A paz sagrada
Do peito teu?
Porém que muito
Que irado esteja
O teu semblante!
Também troveja
O claro Céu.

Na estrofe seguinte descobrem-se os motivos - são ciúmes de outra pastora. 
Eu sei, Marília,

Que outra Pastora

A toda hora,

Em toda a parte

Cega namora

Ao teu Pastor.

Há sempre fumo

Aonde há fogo:

Assim, Marília,

Há zelos, logo

Que existe amor.

E em outra passagem, o sentimento de ciúme atribuído à Marília é explícito.

Deixa o ciúme,

Que te desvela:

Marília bela,

Nesta mesma lira, para assegurar à pastora seu amor, Dirceu lhe faz um elogio lapidar e fulgurante.

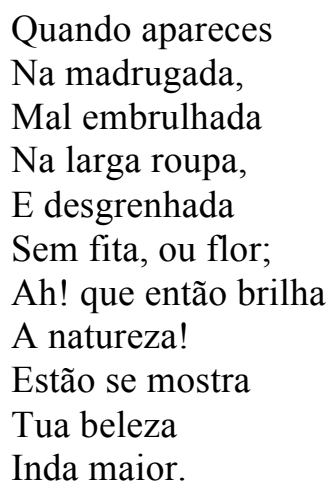

$\mathrm{Na}$ lira I, 20, picada por uma abelha, Marília grita de dor.

Apenas lhe morde, Marília gritando,

C'o dedo fugiu.

Amor, que no bosque

Estava brincando,

Aos ais acudiu.

Em I, 23, Marília aparece assombrada com o canto de Dirceu.

Ela, que teve

De rir-se a ideia,

Nem move os olhos

De assombro cheia: 
Merece especial atenção a forma como o poeta emprega os modos e tempos verbais. Há ocasiões em que encena, diante da interlocutora, com verbos no tempo futuro, situações idílicas envolvendo o casal de sonhos ${ }^{124}$. Esse procedimento ocorre desde a primeira lira.

Irás a divertir-te na floresta

Sustentada, Marília, em meus braços

A mesma cena é apresentada à Marília na lira I, 14. O poeta inicia com um registro argumentativo e sóbrio, aludindo a uma tópica antiga - a passagem do tempo e as transformações que ele causa.

Minha bela Marília, tudo passa;

A sorte deste mundo é mal segura;

Se vem depois dos males a ventura,

Vem depois dos prazeres a desgraça.

Estão os mesmos Deuses

Sujeitos ao poder do ímpio Fado;

Apolo já fugiu do Céu brilhante,

Já foi pastor de gado.

Para desenvolver o tema horaciano do carpe diem, ${ }^{125}$ convida a pastora a "gozar do prazer de sãos amores". Encena então diante dela, a interlocutora, um quadro idílico por meio de verbos no modo imperativo afirmativo, na primeira pessoa do plural.

Ah! Enquanto os Destinos impiedosos

Não voltam contra nós a face irada.

Façamos, sim, façamos, doce amada,

Os nossos breves dias mais ditosos. ${ }^{126}$

Um coração que, frouxo,

A grata posse do seu bem difere,

\footnotetext{
${ }^{124}$ A expressão "casal de sonhos" de certa forma ecoa com certa ironia uma tradição historiográfica que idealiza o casal representado em Marília de Dirceu. A expressão é empregada por Paul Veyne em estudo sobre a elegia erótica romana: "a imaginação dos leitores povoou-se assim de casais de sonhos: Propércio e sua Cíntia, Tibulo e sua Délia, Ovídio e sua Corina." In: VEYNE, 1985, p. 9.

${ }^{125}$ Carpe diem é a formulação do poeta latino Horácio, extraída de suas Ode I,11. O poeta se dirige à Leucono, aconselhando-a a não se preocupar se viverão muito ou pouco, mas beber e aproveitar o presente, pois o futuro é incerto. "Não me perguntes, pois é proibido,/ que fim darão, Leocono, a ti e a mim/ os deuses; nem em adivinhações/ ao modo babilônico confies./ Enfrenta o que cruzar o teu caminho./ Quer tenhas pela frente ainda muitos/ invernos, quer fustigue já a costa/ do mar Tirreno o último que Júpiter/ há de te dar, sê sábio, bebe vinho,/ e espera pouco. Neste mesmo instante/ em que falamos, o invejoso tempo/ de nós já foge. - Aproveita o dia,/ confia no amanhã somente o mínimo." Tradução de Paulo Henriques Britto. Folha de S.Paulo, Caderno Ilustríssima, 9/01/2011.

${ }^{126}$ A mesma tópica aparece em Catulo: "Vivamos, minha Lésbia...”. In: OLIVA NETO, João Angelo. $O$ livro de Catulo. São Paulo: Edusp, 1996.
} 
A si, Marília, a si próprio rouba,

E a si próprio fere.

Ornemos nossas testas com as flores

E façamos de feno um brando leito;

Prendamo-nos, Marília, em laço estreito,

Gozemos do prazer de sãos Amores,

(grifos nossos)

A segunda parte da estrofe retoma o argumento da passagem inexorável do tempo.

Sobre nossas cabeças,

Sem que o possam deter, o tempo corre;

E para nós o tempo, que se passa,

Também, Marília, morre.

E a persona poética volta a demonstrar, com imagens e exemplos, os efeitos corrosivos do transcorrer do tempo: o cansaço do corpo e os sinais de declínio da beleza física.

Com os anos, Marília, o gosto falta,

E se entorpece o corpo já cansado,

Triste, o velho cordeiro está deitado,

E o leve filho sempre alegre salta.

A mesma formosura

É dote que só goza a mocidade:

Rugam-se as faces, o cabelo alveja,

Mal chega a longa idade.

$\mathrm{Na}$ estrofe seguinte, argumentos e exemplos se mesclam na exortação. No início, propõem-se duas perguntas sem resposta, endereçadas à interlocutora.

Que havemos d'esperar, Marília bela?

Que vão passando os florescentes dias?

E na sequência afirma que

As glórias, que vêm tarde, já vêm frias;

E pode enfim mudar-se a nossa estrela.

A exortação final é feita no modo subjuntivo, com a oração na voz passiva.

Ah! não, minha Marília,

Aproveite-se o tempo, antes que faça

$\mathrm{O}$ estrago de roubar ao corpo as forças,

E ao semblante a graça. 
O lugar proeminente que Marília ocupa no discurso de Dirceu, especialmente como destinatária das liras, é fartamente comprovável. Para quantificar a presença da pastora Marília, assinalando as liras em que o nome é mencionado, elaboramos um quadro demonstrativo. A primeira coluna indica a numeração da lira; a segunda, seu primeiro verso; a terceira assinala a presença dela como destinatária; a última registra a menção a Marília, porém destituída da função de interlocutora. 
Quadro 7 - O lugar de Marília na Parte I de Marília de Dirceu

\begin{tabular}{|c|c|c|c|}
\hline Liras & Primeiro verso & $\begin{array}{l}\text { Marília/ } \\
\text { interlocutora }\end{array}$ & $\begin{array}{l}\text { Marília em } \\
\text { outros contextos }\end{array}$ \\
\hline $\mathrm{I}-1$ & $\begin{array}{l}\text { Eu, Marília, não sou algum } \\
\text { vaqueiro, }\end{array}$ & $\mathrm{X}$ & \\
\hline $\mathrm{I}-2$ & Pintam, Marilia, os Poetas & $\mathrm{X}$ & \\
\hline $\mathrm{I}-3$ & $\begin{array}{l}\text { De amar, minha Marilia, a } \\
\text { formosura }\end{array}$ & $\mathrm{X}$ & \\
\hline $\mathrm{I}-4$ & Marília, teus olhos & $\mathrm{X}$ & \\
\hline I-5 & Acaso são estes & $\mathrm{X}$ & \\
\hline $\mathrm{I}-6$ & $\begin{array}{l}\text { Oh! quanto pode em nós a vária } \\
\text { Estrela! }\end{array}$ & $\mathrm{X}$ & \\
\hline $\mathrm{I}-7$ & Vou retratar a Marília, & & $\mathrm{X}$ \\
\hline $\mathrm{I}-8$ & Marilia, de que te queixas? & $\mathrm{X}$ & \\
\hline $\mathrm{I}-9$ & $\begin{array}{l}\text { Eu sou, gentil Marilia, eu sou } \\
\text { cativo; }\end{array}$ & $\mathrm{X}$ & \\
\hline $\mathrm{I}-10$ & Se existe um peito, & & $\mathrm{X}$ \\
\hline $\mathrm{I}-11$ & $\begin{array}{l}\text { Não toques, minha Musa, não, } \\
\text { não toques }\end{array}$ & & $\mathrm{X}$ \\
\hline $\mathrm{I}-12$ & Topei um dia & & $\mathrm{X}$ \\
\hline $\mathrm{I}-13$ & Oh! Quantos riscos, & & $\mathrm{X}$ \\
\hline $\mathrm{I}-14$ & Minha bela Marília, tudo passa; & $\mathrm{X}$ & \\
\hline $\mathrm{I}-15$ & A minha bela Marília & & $\mathrm{X}$ \\
\hline $\mathrm{I}-16$ & Eu, Glauceste, não duvido & & $\mathrm{X}$ \\
\hline $\mathrm{I}-17$ & Minha Marília, & $\mathrm{X}$ & \\
\hline $\mathrm{I}-18$ & $\begin{array}{l}\text { Não vês aquele velho } \\
\text { respeitável, }\end{array}$ & $\mathrm{X}$ & \\
\hline I-19 & $\begin{array}{l}\text { Enquanto pasta alegre o manso } \\
\text { gado, }\end{array}$ & $\mathrm{X}$ & \\
\hline $\mathrm{I}-20$ & Em uma frondosa & & $\mathrm{X}$ \\
\hline $\mathrm{I}-21$ & Não sei, Marília, que tenho, & $\mathrm{X}$ & \\
\hline $\mathrm{I}-22$ & $\begin{array}{l}\text { Muito embora, Marília, muito } \\
\text { embora }\end{array}$ & $\mathrm{X}$ & \\
\hline $\mathrm{I}-23$ & Num sítio ameno, & & $\mathrm{X}$ \\
\hline $\mathrm{I}-24$ & $\begin{array}{l}\text { Encheu, minha Marilia, o grande } \\
\text { Jove }\end{array}$ & $\mathrm{X}$ & \\
\hline $\mathrm{I}-25$ & O cego Cupido um dia & & $\mathrm{X}$ \\
\hline $\mathrm{I}-26$ & O destro Cupido um dia & & $\mathrm{X}$ \\
\hline $\mathrm{I}-27$ & Alexandre, Marília, qual o rio, & $\mathrm{X}$ & \\
\hline $\mathrm{I}-28$ & Cupido, tirando & & $\mathrm{X}$ \\
\hline $\mathrm{I}-29$ & O tirano amor risonho & & $\mathrm{x}$ \\
\hline $\mathrm{I}-30$ & Junto a uma clara fonte & & $\mathrm{X}$ \\
\hline $\mathrm{I}-31$ & Minha Marilia, & $\mathrm{X}$ & \\
\hline $\mathrm{I}-32$ & Numa noite, sossegado, & & $\mathrm{X}$ \\
\hline I-33 & Pega na lira sonora, & & $\mathrm{X}$ \\
\hline
\end{tabular}


Quadro 8 - O lugar de Marília na Parte II de Marília de Dirceu

\begin{tabular}{|l|l|c|l|}
\hline Liras & Primeiro verso & $\begin{array}{l}\text { Marília/ } \\
\text { interlocutoa }\end{array}$ & $\begin{array}{l}\text { Marília em outros } \\
\text { contextos }\end{array}$ \\
\hline II-1 & Já não cinjo de loiro a minha testa, & $\mathrm{X}$ & \\
\hline II-2 & Esprema a vil calúnia muito embora, & $\mathrm{X}$ & \\
\hline II-3 & Sucede, Marília bela, & $\mathrm{X}$ & \\
\hline II-4 & Já, já me vai, Marília, branquejando & $\mathrm{X}$ & \\
\hline II-5 & Os mares, minha bela, não se movem; & $\mathrm{X}$ & \\
\hline II-6 & De que te queixas, & $\mathrm{X}$ & \\
\hline II-7 & Meu prezado Glauceste, & & $\begin{array}{l}\text { a minha bela/ a } \\
\text { bela }\end{array}$ \\
\hline II-8 & Eu vejo, ó minha bela, aquele Númen, & & \\
\hline II-9 & A estas horas & $\mathrm{X}$ & \\
\hline II-10 & Arde o velho barril, arde a cabeça, & & \\
\hline II-11 & Se acaso não estou no fundo Averno, & $\mathrm{X}$ & \\
\hline II-12 & Ah! Marília, que tormento & $\mathrm{X}$ & \\
\hline II-13 & Vês, Marília, um cordeiro & $\mathrm{X}$ & \\
\hline II-14 & Alma digna de mil Avós Augustos! & $\mathrm{X}$ & \\
\hline II-15 & Eu, Marília, não fui nenhum Vaqueiro, & $\mathrm{X}$ & \\
\hline II-16 & Vejo, Marília, & $\mathrm{X}$ & \\
\hline II-17 & Dirceu te deixa, ó bela, & $\mathrm{X}$ & \\
\hline II-18 & Não molho, Marília, & $\mathrm{X}$ & \\
\hline II-19 & Nesta triste masmorra, & $\mathrm{X}$ & \\
\hline
\end{tabular}

\begin{tabular}{|l|l|c|l|}
\hline II-20 & Se me visses com teus olhos & X & \\
\hline II-21 & Que diversas que são, Marília, as horas, & X & \\
\hline II-22 & Por morto, Marilia, & X & \\
\hline II-23 & Não praguejes, Marília, não praguejes & $\mathrm{X}$ & \\
\hline II-24 & Eu vou, Marilia, vou brigar co'as feras! & $\mathrm{X}$ & \\
\hline II-25 & Minha Marilia, & $\mathrm{X}$ & \\
\hline II-26 & Aquele a quem fez cego a Natureza, & $\mathrm{X}$ & \\
\hline II-27 & A minha amada & & a minha amada \\
\hline II-28 & Detém-te, vil humano, & & ó bela \\
\hline II-29 & Eu descubro procurar-me & & \\
\hline II-30 & O Pai das Musas, & $\mathrm{X}$ & \\
\hline II-31 & Roubou-me, ó minha Amada, a sorte ímpia & & ó minha Amada \\
\hline II-32 & Se o vasto mar se encapela, & $\mathrm{X}$ & \\
\hline II-33 & Morri, ó minha Bela; & $\mathrm{X}$ & \\
\hline II-34 & Vou-me, ó Bela, deitar na dura cama, & $\mathrm{X}$ & \\
\hline II-35 & Se lá te chegarem & $\mathrm{X}$ & \\
\hline II-36 & Não hás de ter horror, minha Marília, & $\mathrm{X}$ & \\
\hline II-37 & Meu sonoro Passarinho, & & \\
\hline II-38 & Eu vejo aquela Deusa, & $\mathrm{X}$ & \\
\hline
\end{tabular}


A parte I apresenta o seguinte resultado: em 33 liras, de um total de 33, há menção explícita à Marília, ou seja, 100\% das liras citam nominalmente Marília. Em 17 dessas liras, Marília aparece como interlocutora do eu poético, o que corresponde a $52 \%$ do total. Na parte II, por sua vez, temos a seguinte situação: de um total de 38 liras, 34 mencionam explicitamente Marília, ou seja, 89\% do total referem Marília. Entre essas liras, 30 apresentam-na como interlocutora, o que representa $79 \%$ do total. Se acrescentarmos as referências feitas indiretamente, meio de seus epítetos (a minha bela, ó Bela, a minha Amada, minha amada) temos um total de 38 liras em que a presença de Marília é explícita, ou seja, $100 \%$.

Se considerarmos o total de liras de Marília de Dirceu, somando-se a primeira e a segunda partes, chegamos aos seguintes resultados: ${ }^{127}$ do total de 71 liras que integram o poema (partes I e II), 49 referem-se a Marília como interlocutora explícita, o que representa 69\% das liras; 66 citam seu nome, ou seja, 93\%. As outras denominações como "bela", "ó bela", "a minha bela", “a minha amada", "ó minha amada" em liras que não fazem menção à Marília podem facilmente ser assimiladas ao conjunto das liras e ser consideradas referências à figura de Marília. ${ }^{128}$ Se levarmos esses dados em consideração, a proporção de liras que se referem a Marília aumenta para 100\%, sugerindo homogeneidade ao longo do poema.

Esse número elevado de liras em que a presença de Marília é explícita corrobora nossa a hipótese de que ela seja a figura central, o "núcleo irradiador" do poema, no dizer de Fernando Cristóvão. Um quadro pode figurar melhor a prevalência de Marília a que nos referimos. Para tal, fizemos um levantamento de sua presença considerando o total das liras.

\footnotetext{
${ }^{128}$ Trata-se de cinco liras da parte II. Na lira II, 7 o eu poético pede que Glauceste tome a lira dourada para que a escute "a minha bela": a lira II, 27 faz a pintura da "amada" ("A minha amada/ É mais formosa/Que branco lírio, etc.”). Na lira II, 28, por sua vez, o poeta invoca sua presença ("ó bela") para testemunhar sua força e virtude. Em II, 31, por fim, o eu poético coloca a amada num vocativo: "ó minha Amada". Note-se que perífrases como "gentil pastora", "pastora" e as já citadas são muito frequentes em Marília de Dirceu.
} 
Quadro 9 - Quadro resumo da presença de Marília de Dirceu

* Em Marília de Dirceu, 49 liras de um total de 71 têm Marília como interlocutora explícita - 69\% das liras.

* Em Marília de Dirceu, 66 liras de um total de 71 mencionam explicitamente Marília - 92\% das liras

* Considerando-se as formas "bela", "ó bela", "a minha bela", "a minha amada", "ó minha amada", 71 das 71 liras que compõem Marília de Dirceu referem-se à figura de Marília - 100\% das liras.

Como se pode depreender com segurança, pela prevalência da personagem Marília, a unidade da composição é construída em torno de sua figura. É admirável a força com que Marília é evocada, sobretudo por ocupar o lugar de interlocutora. Levando em conta o critério quantitativo, na maior parte das liras de Marília de Dirceu, a persona poética dirige-se explicitamente a ela. A insistência no nome próprio desdobra-se também nos seus epítetos: as expressões "Marília bela", "minha Marília" e "minha bela Marília" alternam-se nas apóstrofes, ou são substituídas por "ó bela, "minha bela" ou simplesmente “pastora". Essa invocação de Marília é constitutiva do poema e será o recurso que possibilita ao enunciador recolocar a cena pastoral dentro do ambiente do cárcere na segunda parte, o que confere grande integridade à sua obra. Quando não se constitui como figura a que o eu poético se dirige, Marília assume outros papéis, como personagem do idílio pastoril, entidade mitológica ou como pintura de retrato.

\subsection{Marília entre deuses}

A figuração de Marília como personagem mitológica é bastante significativa no conjunto de liras que conforma Marília drceu. Além de protagonista do idílio pastoril e destinatária privilegiada de seu cantor, Marília transita entre deuses ou é a eles comparada. Esse procedimento faz parte das convenções e usos das práticas poéticas do século XVIII. Lembrando que o poema de Gonzaga opera no terreno do discurso epidítico, o poeta utiliza pequenas fábulas ficcionais para ornamentar o discurso e amplificar seus dotes. Na lira I, 2, a aparência de Marília é comparada ao retrato do deus Cupido: 
Arco empunhado na mão; Ligeiras asas nos ombros, O tenro corpo despido, E de Amor ou de Cupido São os nomes, que lhe dão.

Por meio de um procedimento bastante característico desse discurso, o enunciador - depois de encenar a imagem exemplar do deus - opera sua negação:

\author{
Porém eu, Marília, nego \\ Que assim seja Amor, pois ele \\ Não é moço nem é cego, \\ Nem setas nem asas tem. \\ Ora, pois, eu vou formar-lhe \\ Um retrato mais perfeito, \\ Que ele já feriu meu peito; \\ Por isso o conheço bem.
}

O propósito desta comparação em que o poeta emprega litotes é, além de valorizar o retrato de Marília, possibilitar novas galanterias. Comparações e paralelismos são procedimentos recorrentes na ficcionalização da personagem Marília. É o caso da lira I, 10, em que o a persona poética estabelece uma engenhosa relação entre Marília e Cupido, afirmando ter sido Marília quem forneceu as setas mortais ao deus.

Aljava grande,

Dependurada,

Sempre atacada

De bons farpões.

Fere com estas

Agudas lanças

Pombinhas mansas,

Bravos leões.

Se a seta falta,

Tem outra pronta,

Que a dura ponta

Jamais torceu.

Aos golpes dela:

Ninguém resiste

Marília bela

Foi quem lha deu.

Em I, 28, as quadras formadas por redondilhas menores colocam em cena Marília e Cupido, que compartilham o mesmo espaço - um campo de flores. A pastora espera que Cupido adormeça para lhe pregar uma peça - roubar-lhe as setas: 
Dos ombros a aljava,

Num canto de flores

Contente brincava.

E o corpo tenrinho

Depois enfadado,

Incauto reclina

$\mathrm{Na}$ relva do prado.

Marília formosa,

Que ao Deus conhecia,

Oculta espreitava

Quanto ele fazia.

Mal julga que dorme

Se chega contente,

As armas lhe furta,

E o Deus a não sente.

Faunos que presenciaram a brincadeira acodem com risadas. Porém, a reação de Cupido ecoa as gentilezas e atenções de Dirceu, que está ausente da cena.

Os Faunos, mal viram

As armas roubadas,

Saíram das grutas

Soltando risadas

Acorda Cupido,

E a causa sabendo,

A quantos o insultam,

Responde, dizendo:

Temieis as setas

Nas minhas mãos cruas?

Vereis o que podem

Agora nas suas.

Uma nova historieta (também vazada em quadras, em redondilhas maiores) coloca em cena Cupido e sua mãe, Vênus, "junto a uma clara fonte”, no ambiente bucólico. Desta feita, Cupido, vendo a deusa adormecida, julga tratar-se de Marília e lhe dá um beijo. Ao dar-se conta do engano, o deus do Amor se desculpa afirmando a semelhança entre a deusa e a pastora. É o que lemos na lira I, 30:

Junto a uma clara fonte

A mãe de Amor se sentou;

Encostou a mão no rosto, 
No leve sono pegou.

Cupido, que a viu de longe,

Contente ao lugar correu;

Cuidando que era Marília,

$\mathrm{Na}$ face um beijo lhe deu.

Acorda Vênus irada:

Amor a conhece, e então

Da ousadia, que teve,

Assim lhe pede o perdão:

Foi fácil, ó mãe formosa,

Foi fácil o engano meu;

Que o semblante de Marília

$\dot{E}$ todo o semblante teu.

Podemos observar que Marília e Dirceu já se agregaram ao universo mitológico e transitam nele com desenvoltura. $\mathrm{O}$ eu poético fala de si na terceira pessoa, pois é também personagem. ${ }^{129}$ Em I,12, Dirceu entra em conflito com Cupido, ao observar casualmente um momento de vulnerabilidade do poderoso Deus:
Topei um dia
Ao Deus vendado,
Que, descuidado,
Não tinha as setas
Na ímpia mão.

Ao vê-lo Dirceu dá vazão aos seus sentimentos de ira, por se sentir subjugado pelo Deus:
Me sobe logo
Ao rosto o fogo,
Que a raiva acende
No coração.

Mal o conheço

Segue-se um combate feroz em que os dois inimigos se atracam:

Morre, tirano,

Morre, inimigo!

Mal isto digo,

Raivoso o aperto

Nos braços meus.

Sente apertar-se,

Tanto que o moço

\footnotetext{
${ }^{129}$ Trata-se do procedimento retórico da etopeia, que consiste em atribuir um ehos a um personagem, e fazêlo falar e agir de acordo com seu caráter.
} 
Para salvar-se

Também me aperta

Nos braços seus.

Dirceu segue em sua luta impiedosa.

O leve corpo

Ao ar levanto;

$\mathrm{Ah}$ ! e com quanto

Impulso o trago

Do ar ao chão!

Pôde suster-se

A vez primeira;

Mas à terceira,

Nos pés, que alarga,

Se firma em vão.

Mal o derrubo,

Ferro aguçado

No já cansado

Peito, que arqueja,

Mil golpes deu.

Suou seu corpo;

Tremeu gemendo;

E a cor perdendo,

Bateu as asas;

Enfim morreu.

Tendo vencido a peleja com Deus, Dirceu - investido de seu éthos heroico recolhe suas armas do campo de batalha.

Qual bravo Alcides,

Que a hirsuta pele

Vestiu daquele

Grenhoso bruto,

A quem matou;

Para que prove

A empresa honrada,

Co'a mão manchada,

Recolho as setas,

Que me deixou.

Entretanto, a disputa está longe de se encerrar, pois a interferência de Marília imprime desfecho inusitado à guerra instaurada entre Dirceu e Amor. 
Ouviu Marília

Que Amor gritava,

E como estava

Vizinha ao sítio

Valer-lhe vem.

Espavorida,

Mas quando chega

Nem já de vida

$\mathrm{O}$ fero monstro

Indício tem.

Então, Marília,

Que o vê de perto,

De pó coberto,

E todo envolto

No sangue seu,

As mãos aperta

No peito brando,

E aflita dando

Um ai, os olhos

Levanta ao Céu.

Chega-se a ele

Compadecida;

Lava a ferida

C'o pranto amargo,

Que derramou.

Então o monstro

Dando um suspiro,

Fazendo um giro

Co'a baça vista,

Ressuscitou.

Respira a Deusa

E vem o gosto

Fazer no rosto

O mesmo efeito,

Que fez a dor.

A conclusão será o arrazoado galante de Dirceu, indicando a impossibilidade de exterminar o amor que sente por Marília:

Que louca ideia

Foi a que tive!

Enquanto vive

Marília bela,

Não morre Amor.

Humor e graciosidade são marcas dessas pequenas fábulas, às quais o enunciador 
imprime "meia incredulidade quase irônica", como a definiu Eulálio (1983, p. 13). ${ }^{130}$ Outra modalidade de convivência de Marília com seres mitológicos consiste em compará-la a deusas. Colocada em competição com Vênus, Palas ou Juno, Marília vence todas em formosura. Em I, 7, uma cena aristocrática é elaborada pelo poeta para exaltar os predicados da pastora:
Entremos, Amor, entremos, Entremos na mesma Esfera, Venha Palas, venha Juno, Venha a Deusa de Citera, Porém não, que se Marília No certame antigo entrasse Bem que a Páris não peitasse, A todas as três vencera.

Em I, 26, Cupido retrata quatro formosuras em um quadro e compõe um letreiro para indagar quem é a mais bela. Vênus (vencedora no famoso certame em que superou Palas e Hera) cede o lugar a Marília:
O destro Cupido um dia
Extraiu mimosas cores
De frescos lírios, e rosas,
De jasmins, e de outras flores.
Com as mais delgadas penas
Usa de uma, e de outra tinta,
E nos ângulos do cobre
A quatro belezas pinta.
Por fazer pensar a todos
No seu liso centro escreve
Um letreiro, que pergunta:
Este espaço a quem se deve?
Vênus, que viu a pintura,
E leu a letra engenhosa,
Pôs por baixo: Eu dele cedo;
Dê-se a Marília formosa.

$\mathrm{Na}$ abertura da lira II, 27, o enunciador volta a afirmar que Marília excede a deusa em beleza, depois de ser comparada aos mais belos elementos da natureza.

${ }^{130}$ EULÁLIO, Verso e reverso de Gonzaga, p. 13. 
A minha amada

É mais formosa,

Que branco lírio,

Dobrada rosa,

Que o cinamomo,

Quando matiza

Co'a folha a flor.

Vênus não chega

Ao meu Amor.

Em II, 30, a persona poética - encerrada no ambiente soturno da cadeia - realiza um retrato fabuloso da amada, com a lira de ouro que Apolo lhe cede. Aqui também Marília excede Vênus.

O Pai das Musas,

O Pastor loiro

Deu-me, Marília,

Para cantar-te

A lira de ouro.

As cordas firo;

O brando vento

Teus dotes leva

Nas brancas asas

Ao firmamento.

O teu cabelo

Vale um tesouro;

Um só me adorna

A sábia fronte

Melhor que o louro.

Nesses teus olhos

Amor assiste;

Deles faz guerra;

Ninguém lhe foge,

Ninguém resiste.

Algumas vezes

Eu o diviso

Também oculto

Nas lindas covas

Que faz teu riso.

Nesses teus peitos

Têm os seus ninhos

Destros amores;

Neles se geram

Os Cupidinhos. 
Vences a Vênus,

Quando com arte

As armas toma,

Por que mais prenda

Ao fero Marte.

Estas imagens de pintura, cheias de delicadezas e sensualidade, são bruscamente interrompidas por um ruído aviltante, que lembra a triste condição do cantor-prisioneiro.

\author{
Eu produzia \\ Estas ideias, \\ Quando, Marília, \\ O som escuto \\ De vis cadeias. \\ Dou um suspiro, \\ Corre o meu pranto; \\ $\mathrm{E}$, inda bebendo \\ Lágrimas tristes, \\ De novo canto: \\ Sou da constância \\ Um vivo exemplo: \\ $E$ vós, ó ferros, \\ Honrareis inda \\ De Amor o Templo.
}

Diversas outras personagens mitológicas povoam o discurso de Gonzaga em Marília de Dirceu. Embora não faça parte do escopo deste trabalho estudá-la detidamente, a mitologia greco-romana desempenha papel importante nas duas partes do poema. Muitas vezes, as referências do eu poético a personagens e exemplos mitológicos enredam-se com outros componentes estilísticos, como o apelo ao cantor Alceste ou Glauceste, seu duplo na tarefa de enaltecer Marília. 
Em II, 7, Dirceu compara Glauceste a Orfeu e Anfion, em II,7:

Eu sei, eu sei, Glauceste,

Que um bom cantor havia,

Que os brutos amansava,

Que os troncos e os penedos atraía.

De outro destro Cantor também afirma

A sábia Antiguidade

Que as muralhas erguera

De uma grande Cidade.

Orfeu as cordas fere:

O som delgado e terno

Ao Rei Plutão abranda,

E o deixa que penetre o fundo Averno.

O exemplo de exímios músicos, a quem Glauceste iguala ou excede, reforça a exortação que o eu poético faz a seu canto.

$\mathrm{Ah}$ ! tu a nenhum cedes, meu Glauceste,

Na lira e mais no canto:

Podes fazer prodígios,

Obrar ou mais, ou tanto.

Levanta pois as vozes:

Que mais, que mais esperas?

Consola um peito aflito,

Que é menos inda que domar as feras.

Com isto me darás no meu tormento

Um doce lenitivo;

Além de confortá-lo em sua dor, o poeta - por uma espécie de delegação poética de segundo grau - atribui ao canto de Glauceste a incumbência de fazer Marília viver.

Que enquanto a bela vive,

Também, Glauceste, vivo.

Na lira II, 8, Dirceu é convidado por Fortuna a adentrar o Templo para que o pastor conheça o que o destino lhe reserva. A princípio o pastor-poeta-magistrado consegue ver grandes acontecimentos do passado: a fundação de Roma, o incêndio de Cartago, as conquistas de Alexandre. A Deusa então insta Dirceu a conhecer seu próprio futuro; primeiro, promete-lhe devolver a riqueza que lhe subtraiu. Diante da recusa de Dirceu, a Deusa fica aborrecida (“Aqui me enruga a Deusa, irada, a testa,/ E fica sem falar um breve espaço"). Já refeita, oferece-lhe então de volta a glória e o prestígio de que desfrutava, mas Dirceu responde "com ar de mofa": "Conheço-te, Fortuna,/ Posso morrer pequeno". 
Finalmente a Deusa cede e lhe promete restituir o bem mais valioso - Marília:

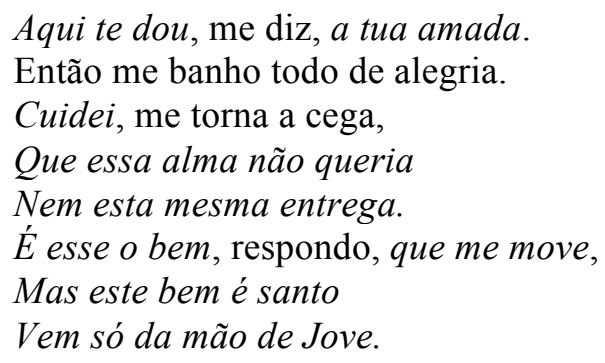

Nesta pequena narrativa, é curioso apreciar o diálogo entre o pastor Dirceu e a deusa Fortuna, tão desiguais em potência. O mundo bucólico empresta o pastor para viver um episódio comumente encontrado em epopeias. É curioso notar certa empáfia de Dirceu, ao agir e reagir sobre as proposições da deusa. Ele afirma na primeira estrofe que a deusa "pega-o pelo braço com voz importuna”. A deusa Fortuna se vale de expressões prosaicas como "Vem comigo" e dirige-se a ele com aparente intimidade ("Alegra, alegra o rosto"). Por fim, Dirceu "dá um basta" no colóquio com a deusa, e aconselha que ela vá cuidar de outros assuntos.

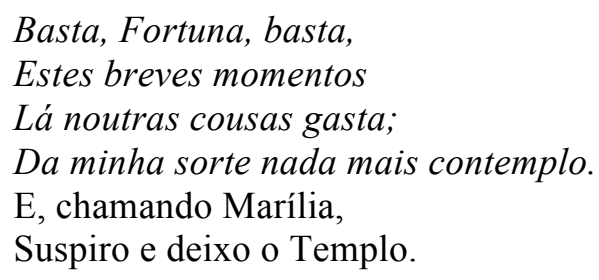

Marília, ou seja, o amor, é mais importante do que a riqueza e a glória que o destino é capaz de lhe restituir; também é mais importante do que a própria deusa.

A lira II,10 tem estrutura narrativa semelhante àquela da lira que acabamos de analisar, mas o convívio entre temas elevados e chãos é ainda mais interessante. $\mathrm{O}$ eu poético narra uma historieta em que é ele mesmo protagonista. Se no primeiro caso encontra-se face a face com a deusa Fortuna na entrada de seu templo, no segundo participa de uma festa junina e realiza uma simpatia, que depois se revela uma trapaça de Cupido. Na primeira estrofe, o narrador se apresenta como um "crédulo Mortal” desejoso de conhecer sua sorte. Faz um breve levantamento das superstições que conhece, mas não tem à mão nem alcachofra nem ovo para realizá-las. Finalmente, recorda-se de uma simpatia de que "ouviu falar": 
Mas ah! em bem me lembre: eu tenho ouvido Que na boca um bochecho d'água tome, E atrás de qualquer porta atento esteja, Até ouvir um nome Que o nome, que primeiro ouvir, é esse O nome, que há-de ter a minha amada; Pode verdade ser; se for mentira, Também não custa nada.

Ao ouvir o nome de Filena ${ }^{131}$, Dirceu chega a cuspir a água:

Vou tudo executar, e de repente Ouvi dizer o nome de Filena Despejo logo a boca: ah não sei como Não morro ali de pena!

Trata-se de mais uma das peças de Cupido:
Aparece Cupido então, soltando Em ar de zombaria uma risada: E que tal, me pergunta, estava a peça? Não foi bem pregada?
Eu já te disse que Marilia é tua; Tu fazes do meu dito tanta conta, Que vais acreditar o que te ensina Velha mulher já tonta?

Cupido zomba do poeta, que acredita numa pobre velha em vez de dar fé a suas determinações. Nota-se aqui a mesma dicção popular, a mesma hibridez que coloca num mesmo plano deuses, velhas crédulas, Cupido, o pastor e a pastora. $\mathrm{O}$ efeito é o de entreter o leitor com essas histórias de final imprevisto. Se no primeiro caso Dirceu despreza a Fortuna, ao abandonar seu templo, no segundo, o pastor se mostra humilde e temeroso quanto ao futuro.

Humilde lhe respondo: Quem debaixo

Do açoite da Fortuna aflito geme,

Nas mesmas coisas, que são só brinquedos,

Se agoiram males, teme.

\footnotetext{
${ }^{131}$ Filena é um nome clássico de prostituta, feiticeira agenciadora do amor venal, de que talvez Gonzaga tivesse conhecimento. Cf. João Angelo Oliva Neto, em comunicação oral na defesa desta dissertação, em $18 / 12 / 2020$.)
} 
Em II, 11, a persona poética é um prisioneiro que se sente no fundo Averno e compara suas aflições aos padecimentos "que aos Precitos/Arbitra Radamanto". ${ }^{132}$ Daí, passa a catalogar aflições e penas oriundas da mitologia, comparando-se àqueles que sofreram castigos terríveis. Lembra-se daqueles que desceram ao Inferno, que fizeram a catábase, ${ }^{133}$ e das Fúrias que enviam serpentes aos mortos. Cita o castigo de Sísifo, condenado a subir indefinidamente uma rocha na montanha, que torna a rolar montanha abaixo. Menciona também as penas de Prometeu, condenado a ter o fígado devorado por abutres, amarrado às rochas. $O$ poeta reflete que, no seu caso, não são os castigos infernais que o afligem, mas um "tormento ainda mais cruel".

Mas sinto de outro monstro a crueldade:

Devora o coração, que mal palpita,

O abutre da saudade.

E chega à conclusão de que sua estrela é mais suave:

Estou no Inferno, estou, Marília bela;

E numa cousa só é mais humana

A minha dura estrela:

Uns não podem mover do Inferno os passos;

Eu pretendo voar, e voar cedo

À glória dos teus braços.

\subsection{Que é este o retrato teu}

Tu, Marília, agora vendo De Amor o lindo retrato, Contigo estarás dizendo Que é este o retrato teu. Sim, Marília, a cópia é tua, Que Cupido é Deus suposto: Se há Cupido, é só teu rosto, Que ele foi quem me venceu.

\footnotetext{
132 Precito: que ou aquele que foi objeto de maldição; réprobo, condenado, maldito. In: Dicionário Houaiss Oonline. Radamante, na mitologia grega, é um dos juízes dos mortos, filho de Zeus e Europa.

${ }^{133}$ Possível referência ao canto VI da Eneida, de Virgílio, em que Eneas desce aos infernos para encontrar seu pai Anquises, capaz de lhe revelar o futuro.
} 
Uma importante formulação da figura de Marília é a imagem de retrato. Calcada na tradição da poesia lírico-amorosa galaico-portuguesa, petrarquista e camoniana, Marília é pintada com os caracteres convencionais da pintura do retrato feminino. Trata-se de uma configuração que segue um ordenamento preconizado pela tradição retórica.

Gonzaga (...) vai continuar a seguir a teoria horaciana do paralelismo das artes na sua versão neoclássica, tanto mais que poetas tão prestigiados como Camões também a fizeram sua. Para ele, portanto, poetar é pintar, e são inúmeros os passos, ao longo das liras, em que tal opção é tomada sem controvérsia. (...) É frequente, ao longo dos poemas a identificação poeta-pintor. Umas vezes, (...) empregando-se simplesmente o verbo "pintar" e mencionando-se os elementos relativos à arte das cores; outras, (...) através da organização descritiva do poema composto à maneira de um retrato de meio-corpo. (CRISTÓVÃO, 1981, p. 56)

Podemos observar o decoro correspondente ao retrato na arte poética de Geoffroi de Vinsauf. ${ }^{134}$ A descrição da figura feminina obedece a uma ordenação, de cima para baixo, que se inicia pelos cabelos e cabeça e desce pelo pescoço, corpo, braços, mãos, pernas e pés: "o esplendor desça desde o alto da cabeça até aos pés, e o todo seja igualmente polido até à perfeição" (VINSAUF, 1990, p. 117). ${ }^{135}$

Se é a beleza de uma mulher que pretendes retratar em toda a sua plenitude: Comece o compasso da Natureza por traçar um círculo para a cabeça; nos cabelos refulja a cor do oiro e floresçam lírios no alto da fronte. A beleza das sobrancelhas iguale a dos negros mirtilos e um caminho lácteo separe os dois arcos gêmeos. $O$ traçado do nariz seja feito com rigor, de maneira que não se detenha antes do ponto justo nem o ultrapasse. Lindos, os olhos, vigias da fronte, brilhem, irmãos gêmeos, com o resplendor das esmeraldas ou o fulgor das estrelas. A face seja êmula da aurora, nem rubra nem alva, mas simultaneamente de ambas as cores e de nenhuma delas. Pequena de feitio e ao jeito de um semicírculo, evidencie-se a boca; os lábios, avultem, vivamente encarnados, mas de um vermelho moderado, ardentes, mas de um fogo brando. Uma disposição harmoniosa alinhe os níveos dentes, todos de igual tamanho. $\mathrm{O}$ odor da boca tenha a mesma essência do incenso. A Natureza, mais poderosa do que a Arte... (VINSAUF, 1990, p. 115)

\footnotetext{
134 Composta entre os anos de 1208 e 1213, segundo o estudioso Edmond Faral. In: VINSAUF, Geoffroi de. Poetria nova. Tradução, introdução e notas de Manuel dos Santos Rodrigues. Lisboa: Instituto Nacional de Investigação Científica/ Centro de Estudos Clássicos da Universidade de Lisboa, 1999. p. 26.

${ }^{135}$ A indicação da obra de Vinsauf é de João Adolfo Hansen. (Informação verbal na aula da disciplina Retórica e Poética, Unifesp, 2019.) Outra fonte importante para a prescritiva do retrato consiste nos Diálogos em Roma, de fins do séc. XVI, de Francisco de Holanda, que serviu para pintores e também poetas.
} 
Gonzaga segue o preceito retórico-poético ordenando a pintura dos olhos, das faces, dos cabelos e do corpo, já na lira de abertura de sua obra, o que estabelece um padrão para o retrato de Marília.

Os teus olhos espalham luz divina,

A quem a luz do Sol em vão se atreve;

Papoila ou rosa delicada e fina

Te cobre as faces, que são cor da neve.

Os teus cabelos são uns fios d'ouro;

Teu lindo corpo bálsamos vapora.

Ah! não, não fez o Céu, gentil Pastora,

Para glória de Amor igual Tesouro.

Graças, Marília bela,

Graças à minha Estrela!

Em sequência, são retratados olhos, faces e cabelos. Segundo levantamento elaborado por Cristóvão (1981, p. 65), ${ }^{136}$ as partes do corpo de Marília retratadas pela persona poética no conjunto das liras (com maior número de ocorrências) são o rosto (face, semblante), os olhos, os cabelos e o peito. Com número menor de ocorrências, mas também em número significativo, estão a boca, as mãos, os beiços, os dentes, os dedos e os braços. Em termos de ordem de apresentação, a maior parte das liras retrata em primeiro lugar o rosto, os olhos ou os cabelos. Em segundo lugar, são apresentados os olhos, a face e os cabelos, e ocasionalmente as sobrancelhas, testa, dentes, mãos e costas. Em terceiro lugar, são mencionados o rosto, os olhos e os cabelos. Conclui-se que o rosto, os olhos e os cabelos são preponderantes nas três posições.

Para melhor compreender a pintura do retrato de Marília, podemos seguir a descrição da lira II, 37, em que o enunciador pede a um passarinho que envie um recado à amada. Para que o mensageiro possa reconhecê-la, ele fornece uma descrição detalhada.

\footnotetext{
${ }^{136}$ Cristóvão trabalha com um corpus composto pelas três partes de Marília de Dirceu, conforme edição de Rodrigues Lapa, de 1937, da Livraria Sá da Costa.
} 
Para bem a conheceres, Eu te dou os sinais todos

Do seu gesto, do seu talhe,

Das suas feições e modos.

O seu semblante é redondo,

Sobrancelhas arqueadas,

Negros e finos cabelos

Carnes de neve formadas.

A boca risonha e breve,

Suas faces cor-de-rosa

Numa palavra: a que vires

Entre todas mais formosa. (grifos nossos)

A caracterização alinha o semblante, sobrancelhas, cabelos, carnes, boca e faces. Observa-se que a adjetivação utiliza exatamente os parâmetros matemáticos mencionados por Vinsauf: o rosto redondo ("Comece o compasso da Natureza por traçar um círculo para a cabeça”), os arcos das sobrancelhas ("um caminho lácteo separe os dois arcos gêmeos"), o cor-de-rosa das faces (“A face seja êmula da aurora, nem rubra nem alva, mas simultaneamente de ambas as cores e de nehuma delas") e a brevidade e o formato da boca ("Pequena de feitio e ao jeito de um semicírculo, evidencie-se a boca"). Os cabelos, nesta lira, são negros e contrastam com a alvura da pele. A oscilação entre a cor dourada e negra dos cabelos de Marília deu ensejo a sérios equívocos entre críticos biografistas, ávidos por reconhecer a realidade empírica por trás do tratamento ficcional. Letícia Malard afirma, em Literatura e dissidência politica, ${ }^{137}$ que

Salvo raras exceções, a crítica e a historiografia literárias vêm-se empenhando em focalizar a lira de Gonzaga preferencialmente pelo sentimento amoroso dedicado a uma rica adolescente e seu entorno, colando-se o imaginário desejável ao real hipotético. De alguma forma, ratifica-se o discurso extraliterário de encantamento e insegurança de um quarentão apaixonado por uma donzela de cabelos ora negros, ora loiros inexplicavelmente -, desprovida de fala própria em seu recato de meninamoça. Nesse enfoque se procura contabilizar o real da vida - mais suposto que comprovado - com o imaginário da arte - mais mimético do que inventivo, segundo a normatização da Arcárdia. (MALARD, 2006, p. 119-120)

Em I, 7, o poeta tematiza em quatro estrofes a pintura do retrato de Marília, sem se dirigir a ela, mas ao deus Amor. A lira abre-se com o desejo do poeta de retratar Marília: 
Vou retratar a Marília,

A Marília, meus amores:

Porém como? se eu não vejo

Quem me empreste as finas cores

Dar-mas a terra não pode:

Não, que a sua cor mimosa

Vence o lírio, vence a rosa,

$\mathrm{O}$ jasmim e as outras flores

Uma vez que as flores, elementos encontrados na terra, não podem fornecer as tintas para pintar a amada, no estribilho o poeta pede o socorro do deus Amor para trazer tintas do céu, supostamente dignas da pintura de Marília.

Ah! socorre, Amor, socorre
Ao mais grato empenho meu!
Voa sobre os Astros, voa,
Traze-me as tintas do Céu.

Em seguida, o poeta recrudesce seu esforço, unindo-o ao de Cupido, para recorrer às cores produzidas no mar, como pérolas e corais. Num movimento ascensional, chega até o firmamento, para concluir que as auroras e as estrelas também não bastam para pintar Marília.

Mas não se esmoreça logo;

Busquemos um pouco mais;

Nos mares talvez se encontrem

Cores que sejam iguais.

Porém não, que em paralelo

Da minha ninfa adorada,

Pérolas não valem nada,

Não valem nada os corais.

Ah! socorre, Amor, socorre

Ao mais grato empenho meu!

Voa sobre os Astros, voa,

Traze-me as tintas do Céu.

Só no céu achar-se podem

Tais belezas como aquelas,

Que Marília tem nos olhos,

E que tem nas faces belas;

Mas às faces graciosas,

Aos olhos negros, que matam,

Não imitam, não retratam

Nem auroras nem Estrelas.

Ah! socorre, Amor, socorre

Ao mais grato empenho meu!

Voa sobre os astros, voa,

Traze-me as tintas do Céu. 
Em termos de elocução, uma das mais interessantes características que salta aos olhos do leitor/ouvinte nos versos de Marília de Dirceu é aquela que se refere à visualidade. Não apenas o cenário pastoril; a caracterização das personagens e o retrato esplêndido de Marília compõem a descrição ou écfrase gonzaguiana. Como explica o estudioso Paulo Martins,

O gênero Idílio ( $\varepsilon i \delta v ́ \lambda \lambda$ iov) está fundado no caráter visual: não é à toa que o nome do gênero, seja ele antigo, seja tardio, tenha o mesmo étimo de

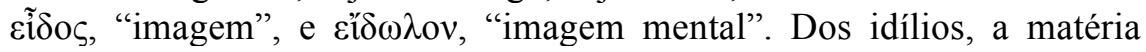
bucólica é parte nos autores gregos (Teócrito, Mosco e Bíon), mas não em Virgílio, em que comparece em todos os poemas desse gênero, agora também chamado "bucólico". Em suma, se nos autores gregos não se podem rigorosamente identificar idílio e bucólica, em Virgílio eles coincidem. Em Virgílio, pois, a poesia bucólica é gênero poético cujo cerne é a visualidade ou visualização daquilo que é operado verbalmente; pode, portanto, ser considerada como a "pintura que fala", parafraseando Simônides. ${ }^{138}$

Mas como seria composta tal visualidade?

A visualidade tem uma relação indene e essencial com os preceitos retórico-poéticos que norteiam a écfrase, que grosso modo se pode entender por "descrição". A écfrase na verdade pretende produzir a enargia (Ẻvó $\rho \gamma \varepsilon 1 \alpha$ ), isto é, a vividez da descrição. Tal qualidade descritiva, que pode ser entendida retoricamente como virtude da elocução, é elemento textual particularmente estratégico, porque imprime movimento aos elementos estáticos da imagem, isto é, transforma, na imagem, o que é estático em cinético e assim une descrição - cuja matéria em princípio são só objetos e cenas - à narração - cuja matéria são ações e eventos. Bem por causa da enargia, a descrição, que então será ecfrástica, difere das meras descrições de objetos estáticos. ${ }^{139}$

A utilização da écfrase pode ser exemplificada na composição de cenas dinâmicas, como ocorre na lira II, 5.

Os mares, minha bela, não se movem;

O brando Norte assopra, nem diviso

Uma nuvem sequer na Esfera toda:

\footnotetext{
${ }^{138}$ MARTINS, Paulo. Memorial. Memorial Apresentado ao Departamento de Letras Clássicas e Vernáculas da Faculdade de Filosofia, Letras e Ciências Humanas da Universidade de São Paulo para Obtenção do Título de Livre-Docente. Universidade de São Paulo, Faculdade de Filosofia, Letras e Ciências Humanas, Departamento de Letras Clássicas e Vernáculas. São Paulo, 2013. p. 28. Acesso em: set. 2020.

${ }^{139}$ MARTINS, Paulo. Idem, ibidem.
} 
O poeta compara o governo de uma nau à condução da própria vida, uma tópica recorrente na tradição clássica. Os mares que não se movem, o vento que assopra brandamente e o céu azul, sem nuvens, compõem um quadro sugestivo e cinestésico da calmaria. Esse quadro se aviva quando "a sorte muda", como lemos na segunda estrofe:

Mas ah! que o Sul carrega, o mar se empola, Rasga-se a vela, o mastro se parte!

Poucos elementos (vento, mar empolado, vela que se rasga, mastro que se parte) colocados em sequência e em gradação operam um cenário de tormenta. $\mathrm{O}$ leitor consegue "ver" a sequência dos acontecimentos e ao mesmo tempo ter uma ideia do quadro geral. A vivacidade e intensidade são conseguidos pelo movimento obtido com os verbos que indicam ação, que são empregados no presente do indicativo e na voz reflexiva. Numa sugestão de autonomia dos elementos da natureza (vento Sul, mar) e, por metonímia, o barco, como se dotado de vontade própria, escapa ao controle do piloto. A conclusão é evidente:

Qualquer varão prudente aqui já teme: 10

Não tenho a necessária força e arte.

Corra o Sábio Piloto, corra e venha

Reger o duro leme.

Embora o argumento pareça intrincado ou complexo, a aparência de simplicidade impera. A visualidade gera efeitos (éticos ou patéticos) no leitor. Trata-se de um mecanismo retórico-poético em que as necessidades argumentativas (inventio), o desenvolvimento lógico (dispositio) e a fruição do texto (elocutio) geram a visualidade e, por consequência, o efeito (ético ou patético) sobre o leitor ou ouvinte. 


\title{
3.5. Então mais vivamente te diviso
}

\author{
Quando em eu mal pondero, \\ Então mais vivamente te diviso: \\ Vejo o teu rosto, e escuto \\ A tua voz, e riso. \\ Movo ligeiro para o vulto os passos; \\ Eu beijo a tíbia luz em vez de face, \\ E aperto sobre o peito em vão os braços.
}

É pertinente lembrar que a lira II, 15 refaz, quase termo a termo, a lira I, 1, num elaborado procedimento intertextual.

Eu, Marília, não fui nenhum Vaqueiro,

Fui honrado Pastor da tua Aldeia;

Vestia finas lãs e tinha sempre

A minha choça do preciso cheia.

Tiraram-me o casal e o manso gado,

Nem tenho, a que me encoste, um só cajado.

Para ter que te dar, é que eu queria

De mor rebanho ainda ser o dono;

Prezava o teu semblante, os teus cabelos

Ainda muito mais que um grande Trono.

Agora que te oferte já não vejo,

Além de um puro amor, de um são desejo.

Trata-se da figuração da derrocada da condição de vida abastada e do pastor honrado entre seus pares. ${ }^{140}$ Os elementos se sucedem: lãs, choça, casal, gado, cajado. A gradação culmina com a figura patética do pastor destituído de todos os seus bens, até do seu cajado. Poderíamos aventar a hipótese de que, uma vez sem o cajado (símbolo da poesia bucólica, bem como a sanfoninha), a matéria pastoral também se esvaísse. Bem o contrário decidiu o poeta. Utilizou a écfrase negativa (descrição do que não tem, mas evoca exatamente o que tem na mente do ouvinte/leitor). Tudo aquilo que tinha destinava-se à Marília.

Se o rio levantado me causava,

\footnotetext{
${ }^{140}$ Para estudar a figura do pastor honrado e os aspectos sociais da corte portuguesa no século XVIII, cf. RUEDAS DE LA SERNA, Jorge Antonio. Op. cit. e HANSEN, João Adolfo. As liras de Gonzaga: entre retórica e valor de troca. Via Atlântica, n. 1, 1997, p. 40-53.
} 
Levando a sementeira, prejuízo,

Eu alegre ficava, apenas via

$\mathrm{Na}$ tua breve boca um ar de riso.

Tudo agora perdi; nem tenho o gosto

De ver-te ao menos compassivo o rosto.

É possível analisar essa dinâmica da retomada de termos e tópoi no livro como um mecanismo de coesão e, ainda mais, como evidência de que a persona poética costura e amarra internamente as duas partes de Marília de Dirceu como um mesmo livro. Se contrastarmos as duas partes, verificamos a figura de Marília é um elo que dá coesão ao livro, tornando os dois momentos complementares de uma mesma obra. Alexandre Eulálio formulou a hipótese de que poeta Tomás Antônio Gonzaga tenha percorrido uma trajetória em que, partindo de determinado projeto poético - a elaboração do idílio campestre, fixado na figura de Marília, musa definitiva de quantas Lidoras e Nises houvesse antes dela -, defronta-se com um "imprevisto apêndice" que constitui a segunda parte das liras.

Quanto às composições do cárcere, que integrarão a segunda parte, Gonzaga deve tê-las considerado sempre imprevisto apêndice ao idílio bucólico; uma releitura penosa que decerto o perturbou até o fim da vida. (EULÁLIO, 1983, p. 9 )

A lira de abertura da segunda parte de Marília de Dirceu estabelece a reinvenção do programa poético de Tomás Antônio Gonzaga. São onze estrofes de cinco versos que combinam dois versos decassílabos e três redondilhas menores. O esquema de rimas é ABacxb (maiúsculas para os versos decassílabos; minúsculas para as redondilhas menores e x para o verso que não apresenta rima).

Já não cinjo de loiro a minha testa,

Nem sonoras Canções o Deus me inspira:

$\mathrm{Ah}$ ! que nem me resta

Uma já quebrada,

Mal Sonora Lira!

Mas neste mesmo estado em que me vejo,

Pede, Marília, Amor que vá cantar-te:

Cumpro o seu desejo;

$\mathrm{E}$ ao que resta supra

A paixão e a arte.

A fumaça, Marília, da candeia,

Que a molhada parede ou suja ou pinta,

Bem que tosca e feia,

Agora me pode

Ministrar a tinta. 
Aos mais preparos o discurso apronta:

Ele me diz que faça no pé de uma

Má laranja ponta,

E dele me sirva

Em lugar da pluma.

Perder as úteis horas não, não devo;

Verás, Marília, uma ideia nova:

Sim, eu já te escrevo,

Do que esta alma dita,

Quanto amor aprova.

Quem vive no regaço da ventura

Nada obra em te adorar, que assombro faça;

Mostra mais ternura

Quem te estima e morre

Nas mãos da desgraça.

Nesta cruel masmorra tenebrosa

Ainda vendo estou teus olhos belos,

A testa formosa,

Os dentes nevados,

Os negros cabelos.

Vejo, Marília, sim, e vejo ainda

A chusma dos Cupidos, que pendentes

Dessa boca linda,

Nos ares espalham

Suspiros ardentes.

Se alguém me perguntar onde eu te vejo,

Responderei - no peito - que uns Amores

De casto desejo

Aqui te pintaram,

E são bons Pintores.

Mal meus olhos te viram, ah! nessa hora

Teu retrato fizeram, e tão forte,

Que entendo que agora

Só pode apagá-lo

O pulso da Morte.

Isso escrevia, quando, ó Céus, que pejo!

Descubro a ler-me os versos o Deus loiro.

Ah, dá-lhes um beijo,

E diz-me que valem

Mais que letras de oiro!

Vamos proceder à análise dessa lira que dialoga com a lira 1 da parte $\mathrm{I}$, tanto em termos de matéria quanto de elocução. Ambas tratam dos bens, dos atributos e das virtudes do poeta e do amor de Marília. 
Já não cinjo de loiro a minha testa,

Nem sonoras Canções o Deus me inspira:

Ah! que nem me resta

Uma já quebrada,

Mal Sonora Lira!

O mesmo Dirceu que na primeira parte era cantor que "concertava a voz celeste", vê-se agora em situação diametralmente oposta. A elocução também utiliza a litotes: o enunciador não possui mais seu instrumento e lhe foge a inspiração divina que alentava seus versos. O locus amoenus teria transformado-se, a princípio, num locus horrendus - o cárcere escuro onde o poeta agora vive, privado de sua liberdade, de seus bens e sua honra. No entanto, ao apresentar a Marília neste desalentado estado, anuncia que tem ainda a incumbência dada por Cupido de continuar a cantá-la, mostrando-se disposto a atendê-lo prontamente. Por certo, ainda lhe resta "paixão" e "arte", ou seja, afeto e engenho.

Mas neste mesmo estado em que me vejo,

Pede, Marília, Amor que vá cantar-te:

Cumpro o seu desejo;

$\mathrm{E}$ ao que resta supra

A paixão e a arte.

A estrofe seguinte demonstra o engenho do prisioneiro, ao mesmo tempo que revela ao leitor seu estado deplorável na masmorra.

A fumaça, Marília, da candeia,

Que a molhada parede ou suja ou pinta,

Bem que tosca e feia,

Agora me pode

Ministrar a tinta.

Aos mais preparos o discurso apronta:

Ele me diz que faça no pé de uma

Má laranja ponta,

E dele me sirva

Em lugar da pluma.

Incontinenti, o encarcerado se anima com "uma ideia nova” que já torna "úteis" as horas que passa no cárcere:

Perder as úteis horas não, não devo;

Verás, Marília, uma ideia nova:

Sim, eu já te escrevo,

Do que esta alma dita,

Quanto amor aprova.

$\mathrm{Na}$ estrofe central da lira, a persona poética desenvolve o arrazoado com o qual 
prosseguirá. $\mathrm{O}$ argumento que serve tanto para o afeto quanto para a excelência do discurso poético diz que aquele que "morre na desgraça" e ama vale ainda mais que aquele que "vive no regaço da ventura". Amar e compor versos são bastante semelhantes. O oxímoro une as duas pontas da lira:

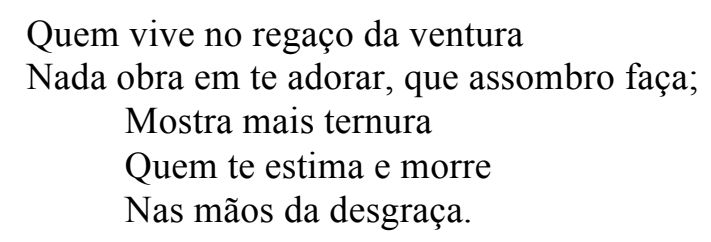

O retrato de Marília, fiel àquele pintado na primeira parte, autoriza o eu poético a recuperar o imaginário pastoral que havia concebido. Note-se que esta passagem do imaginário da primeira parte ao da segunda faz-se com a referência aos olhos da persona poética, que se encontram com os olhos da amada. Em meio a uma dicção elegíaca, em que lamenta a própria sorte, o poeta encontra a simplicidade e a disposição que mostrava nas odes da primeira parte.

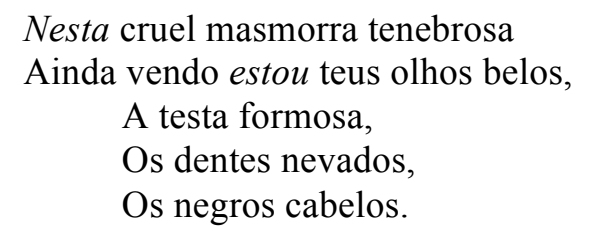

Esta estrofe figura o movimento que o poeta faz em contrastar o ambiente escuro da masmorra com a imagem (ou o retrato) solar de Marília. A figura de Marília traz para a masmorra o imaginário pastoril tão minuciosamente elaborado. Talvez por contaminação do adjetivo "tenebrosa", Marília aqui tem os cabelos negros. Resta adorná-la com requintes preciosos. No retrato que lhe faz, o eu poético pinta ainda uma "chusma de Cupidos" que, além de adornarem seu rosto, amplificam seus suspiros pelos ares:

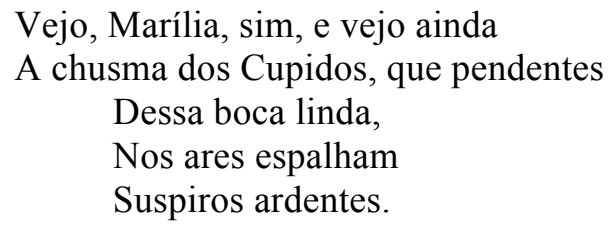

Note-se que o retrato de Marília obedece ao mesmo paradigma estabelecido na lira I,1, com adjetivos simples e a referência ao contraste entre seus dentes nevados e os cabelos pretos. Antecipando uma possível réplica, o eu poético explica "onde vê Marília", uma vez que está encerrado na masmorra. 
Se alguém me perguntar onde eu te vejo,

Responderei - no peito - que uns Amores

De casto desejo

Aqui te pintaram,

E são bons Pintores.

A persona poética argumenta que se o retrato de Marília foi pintado por Amores só a Morte pode apagá-lo. É uma maneira de colocar Marília neste novo cenário, tão distante da cena bucólica das liras da primeira parte.

Mal meus olhos te viram, ah! nessa hora

Teu retrato fizeram, e tão forte,

Que entendo que agora

Só pode apagá-lo

O pulso da Morte.

A Morte é a única condição para que se apague o retrato de Marília. Como a palavra Morte encerra a estrofe, o poeta realiza um movimento temporal que coloca Dirceu num momento posterior àquele de seus escritos. Com um arremate galante, invoca a intervenção de Apolo, que sempre inspirou seus versos:

Isso escrevia, quando, ó Céus, que pejo!

Descubro a ler-me os versos o Deus loiro.

Ah, dá-lhes um beijo,

E diz-me que valem

Mais que letras de oiro!

A menção ao valor das letras "de oiro" contrapõe-se ao pedúnculo da má laranja que lhe serve de pluma e à tinta enegrecida dos fumos na parede do cárcere. A retomada do assunto ou tema das composições da primeira parte e da tópica pastoril é evidente. Mudase o cenário e a condição de Dirceu, que passa de pastor-poeta-magistrado para réu de Sua Majestade no cárcere. Mas não se altera seu éthos, forjado no amor por Marília. 
4. CONCLUSÃO 
A composição poética de Tomás Antônio Gonzaga intitulada Marília de Dirceu pode ser compreendida como um poema unitário, organizado e articulado em torno da elaboração da figura de Marília. A leitura da fortuna crítica da obra identificou, numa linha do tempo que vai da primeira publicação do livro (Parte I) em 1792, até o início dos anos 1980, a subordinação da obra lírica do poeta aos pressupostos românticos de expressão de sentimentos reais de um sujeito empírico, ao projeto nacionalista formulado no Brasil no século XIX e aos efeitos de uma mitologia construída em torno da participação de Gonzaga no episódio da Conjuração Mineira. A combinação de circunstâncias históricas, políticas, biográficas e literárias levou a uma moldagem persistente da recepção crítica da obra atribuída a Gonzaga. Além disso, escolhas editoriais que acrescentaram, suprimiram ou rearranjaram a ordem das liras dificultaram a leitura do poema como artefato retóricopoético, unitário e regulado pelas convenções poéticas e prescrições de seu tempo. A compreensão da presença recorrente da pastora Marília no poema também moldou-se durante um bom tempo pela figura histórica que a teria inspirado.

Neste trabalho, foram observados diversos aspectos compositivos de Marília de Dirceu, em termos de matéria, tópicas e procedimentos poéticos e retóricos a partir da análise da lira I,1, considerada programática, por ser a lira de abertura do livro. Verificouse a estrutura estrófica das liras, o uso de metros diversos, os variados esquemas de rimas o manejo do estribilho, aliados a uma aparente simplicidade lexical e sintática, geradores de um efeito de naturalidade, clareza e vivacidade. As análises quantitativas revelaram a presença abrangente de Marília como elemento constitutivo desse discurso. A persona poética (o pastor Dirceu) interpela Marília com grande diversidade de procedimentos linguísticos e estratégias persuasivas. Marília compõe, ao lado de Dirceu, um "casal de sonhos" como aqueles da elegia erótica latina: Propércio e Cíntia, Tibulo e Délia e Ovídio e Corina. Marília, no entanto, é uma pastora, personagem do idílio pastoril e habita o cenário bucólico, o locus amoenus, com os elementos que o compõem: a fonte, a relva, o regato, flores, especialmente rosas e boninas. Em termos gerais, podemos situar a composição gonzaguiana no gênero lírico de matéria bucólica, e apontar que ela apresenta elementos de gêneros fronteiriços como a elegia, a ode e a poesia epigramática. Diversas tópicas aparecem no poema como a do convite amoroso, da brevidade da vida, da perenidade da poesia e da formosura da amada. "Como é Marília de Dirceu?" foi a pergunta que buscamos responder neste trabalho. Verificamos a presença recorrente de Marília como um nome - acompanhado de seus epítetos (Marília bela, Marília formosa, 
minha Marília) - que atravessa toda a tradição do gênero bucólico, numa tópica de longa duração, de Teócrito a Bocage. O papel discursivo mais evidente de Marília é o de interlocutora - aquela que assegura a situação discursiva. Em algumas liras, ela cede lugar a Alceste, Glauceste ou Amor, entretanto, do total de 71 liras que integram Marília de Dirceu (partes I e II), quase 70\% têm Marília como interlocutora explicita e 93\% citam seu nome, de uma forma ou de outra. Se somarmos outras denominações como "bela", "ó bela", "a minha bela" e "a minha amada", que podem facilmente ser assimiladas à figura de Marília, a proporção de liras que se referem a ela aumenta para $100 \%$, o que torna essa composição poética totalmente homogênea. Embora à primeira vista Marília se apresente como uma figura estática, contemplativa e "sem voz", o enunciador frequentemente faz um esforço para trazer a destinatária para perto de si e dotá-la de vida, para atribuir-lhe estados e humores variados. A destinatária é constantemente interpelada, seja pela verbalização de seu nome, seja pela reiteração do chamado do enunciador, que a convida a compartilhar de suas fantasias e invenções poéticas.

O discurso do poeta modula a presença de Marília ou, dizendo de outro modo, Marília se apresenta sob múltiplas "facetas", que se constituem poeticamente e se articulam dentro das liras. Nesse sentido, Marília pode ser compreendida como a) uma pastora do idílio pastoril b) um nome da tradição bucólica, c) uma interlocutora privilegiada, d) uma personagem mitológica (que convive com deuses e se compara a deusas) e e) uma imagem de retrato (ordenada retoricamente a partir das preceptivas poéticas). Por fim, cabe notar o papel determinante que Marília tem ao unir as duas partes de Marilia de Dirceu. Ela opera uma espécie de intermédio conciliatório, Ressaltamos a estratégia poética de Gonzaga de revalorizar seu discurso, agenciando temas e matéria, além de formas elocutivas disseminadas na primeira parte, na constituição da segunda parte de Marília de Dirceu. Seja pastora, personagem, interlocutora ou figura de retrato, é esta mesma Marília que permite que Dirceu/Gonzaga consiga erguer seu "monumento mais perene que o bronze". ${ }^{141}$

\footnotetext{
${ }^{141}$ Horácio, Ode 3,30. Tradução de Haroldo de Campos. "Mais perene que o bronze um monumento/ ergui, mais alto e régio que as pirâmides,/ nem o roer da chuva nem a fúria/ de Áquilo o tocarão, tampouco o tempo/ ou a série dos anos. Imortal/ em grande parte, a morte só de um pouco/ de mim se apossará. Que eu sempre novo,/ acrescido em louvor, hei de crescer/ enquanto ao Capitólio suba o Sumo/ Sacerdote e a calada vestal. Aonde/ violento o Áufido espadana, aonde/ depauperado de água o Dauno agrestes/ povos regeu, de humilde a poderoso/ dirão que passei: príncipe, o primeiro/ em dar o eólio canto ao modo itálico./ Assume os altos méritos, Melpómene:/ cinge-me a fronte do laurel de Apolo.
} 


\section{REFERÊNCIAS BIBLIOGRÁFICAS}

\section{Do autor (por data de publicação)}

T. A. G., Marilia de Dirceu (parte I). Porto: Typografia Nunesiana, 1792.

., Marília de Dirceu (partes I e II). Lisboa: Oficina Nunesiana, 1799.

., Marília de Dirceu. Lisboa: Bulhões, 1800.

., Marília de Dirceu. Lisboa: Nunesiana, 1802.

., Marília de Dirceu. Rio de Janeiro: Imprensa Régia, 1810.

., Marilia de Dirceu. Lacerdina, 1811.

., Marília de Dirceu. Partes I, II e III. Lisboa: Impressão Régia, 1812.

. Marília de Dirceu. (Ed.) Manuel Pereira da Silva. [s.1.]: Laemmert, 1945.

. Marília de Dirceu. (Org.) Joaquim Norberto de Souza e Silva. Rio de Janeiro:

Garnier, 1862.

. Marília de Dirceu. (Org.) José Veríssimo. Rio de Janeiro: Garnier, 1908.

. Marília de Dirceu (Seleção das liras autênticas). (Ed. lit.) Alberto Faria. Rio de Janeiro: Anuário do Brasil, 1922.

. Marília de Dirceu. Int. pref. e notas do prof. Rodrigues Lapa. Lisboa: Ed. Sá da Costa, 1937. (2 ${ }^{\mathrm{a}}$ ed, 1944 e $3^{\mathrm{a}}$ ed. 1961)

- Obras completas de Tomás Antônio Gonzaga. Poesias - Cartas Chilenas.

Edição crítica de M. Rodrigues Lapa. Rio de Janeiro: MEC-INL, 1957. (1ª ed.1942, com erros).

. Marília de Dirceu. Introdução de Manuel Cavalcanti Proença. Rio de Janeiro: Tecnoprint, 1967 (Ed. de Ouro).

Os melhores poemas de Tomaz Antônio Gonzaga. Seleção, introdução e notas de Alexandre Eulálio. São Paulo: Global, 1983. 
. Marília de Dirceu. (Org.) Melânia Silva de Aguiar. Belo Horizonte: Vila Rica, 1992.

. Marília de Dirceu. Edição do bicentenário (1792-1992). Prefácio e notas de Melânia Silva Aguiar. Rio de Janeiro: Livraria Garnier, 1992.

GONZAGA, Tomás Antônio. Marília de Dirceu / por T.A.G. - Rio de Janeiro: Fundação Biblioteca Nacional, Dep. Nacional do Livro, 1995. Fac-símile de: Lisboa: na Typografia Nunesiana, 1792.

PROENÇA FILHO, D. (Org.) A poesia dos inconfidentes: poesia completa de Cláudio Manuel da Costa, Tomás Antônio Gonzaga e Alvarenga Peixoto. Artigos, ensaios e notas de Melânia Silva de Aguiar et alli. Rio de Janeiro: Nova Aguilar, 1996.

GONZAGA, T.A. Cartas chilenas. (Ed.) Afonso Arinos de Melo Franco. Rio de Janeiro: Ministério da Educação e Saúde, 1940.

\section{Traduções (por data de publicação)}

Marilie, chants élégiaques de Gonzaga. Trad. Eugène de Monglave e Prosper Chalas. Paris: Panckoucke, 1825 (versão em prosa literária).

Marilia de Dirceo: lire di Tommaso Antônio Gonzaga brasiliano. Trad. Giovenale Vergezzi- Ruscalla. Torino: Stamperia Sociale degli Artisti, 1844.

Amaryllidos Dircaei. Trad. Antônio de Castro Lopes. Rio de Janeiro: Tipografia Quirino \& Irmãos, 1868 (tradução latina para uso nas escolas do Império, 1868-1887).

GONZAGA, T. A. "Eu, Marília, não sou algum vaqueiro" (Lira I, 1). Tradução de Ferdinand Schmid. Berlim: Gebrüder, 1879.

. "A estas horas" (Lira II, 9). Trad. Alexander Sergueievitch Pushkin, 1825 (para o russo, a partir da versão francesa). In: PÚCHKIN. Aleksandr. Obras completas em 10 volumes. Moscou: Academia de Ciências, 1956-1958; vol. II. p. 298.

. Marilia de Dirceo. Trad. e notas de Jorge Ruedas de La Serna. Ed. bilíngue. México, São Paulo: Fondo de Cultura Economica/Edusp, 2002. 


\section{Estudos sobre o autor}

AGUIAR, Melânia Silva de. Marília de Dirceu: a lição retificadora das fontes. Disponível em: http://www.macua.org/coloquio/MARILIA_DE_DIRCEU_Melania_Aguiar.htm. Acesso em: mar. 2017.

AMORA, Antônio Soares. Tomás Antônio Gonzaga. In: . Panorama da poesia brasileira e luso-brasileira. Rio de Janeiro: Civilização Brasileira, 1959. p. 98-123.

ÁVILA, Afonso. A natureza e o motivo edênico na poesia colonial. In: . O poeta e a consciência crítica. Petrópolis : Vozes, 1969. p. 27-35.

BOSI, Alfredo. Árcades ilustrados. In: . História concisa da literatura brasileira. São Paulo: Cultrix, 1978. p. 78-84.

CANDIDO, Antônio. Letras e ideias no período colonial. In: . Literatura $e$ sociedade: estudos de teoria e história literária. São Paulo: Nacional, 1965. p. 105-128.

. Naturalidade e individualismo de Gonzaga. In: Formação da literatura brasileira: momentos decisivos. 5. ed. Belo Horizonte: Itatiaia; São Paulo: Edusp, 1975. p. 114-126.

. Uma aldeia falsa. In: Na sala de aula. 8. ed. São Paulo: Ática, 2005. p. 20-37.

. Entre pastores. In: $O$ observador literário. 4. ed. Rio de Janeiro: Ouro sobre Azul, 2008.

CANDIDO, A.; CASTELlO, A. Presença da literatura brasileira. São Paulo-Rio de Janeiro: Difel, 1980, v. I.

CASTELO, José Aderaldo. A época arcádica. In:_. A literatura brasileira: manifestações literárias da era colonial. $2^{\mathrm{a}}$. edição revista e comentada. São Paulo: Cultrix, 1965. p. 131-188.

CASTRO ALVES, Antônio. Gonzaga ou a revolução de Minas. Drama histórico brasileiro. Rio de Janeiro: Cruz Coutinho, 1875.

CRISTÓVÃO, Fernando. Marília de Dirceu de Tomás António Gonzaga ou a poesia como imitação e pintura. (Série Temas Portugueses) Lisboa: Imprensa Nacional/Casa da Moeda, 1981.

DUTRA, Waltensir. Tomás Antônio Gonzaga. In: COUTINHO, Afrânio (ed.). A literatura no Brasil. Rio de Janeiro: Sul Americana, 1956. v. 1, t. 1, p. 470-480. 
EULÁLIO, Alexandre. Obra. Verso e reverso de Gonzaga. Dirceu poeta e prisioneiro. In: As melhores poesias de Tomás Antônio Gonzaga. São Paulo, Global, 1983.

. Nota bio-bibiográfica. In: As melhores poesias de Tomás Antônio Gonzaga. São Paulo: Global, 1983.

FARIA, A. Acendalhas: literature e folklore. Rio de Janeiro: Leite Ribeiro, 1920.

FRANCO, Afonso Arinos de Melo. Introdução. In: GONZAGA, Tomás Antônio. Marilia de Dirceu. São Paulo: Martins, 1944. p. vii-xii.

FREITAS, Leandro César Albuquerque de. Ecos bucólicos: relações entre as Bucólicas de Virgílio e a primeira parte da Marília de Dirceu de Gonzaga. Dissertação (Mestrado) CCHLA-UFP. 2008.

FRIEIRO, E. O diabo na livraria do cônego - Como era Gonzaga? e outros temas mineiros. $2^{\text {a }}$ edição revista e aumentada. São Paulo: Editora Itatiaia/Edusp, 1981.

FURTADO, Joaci Pereira. A sorte deste mundo: percursos de Marília de Dirceu no século XIX. Literatura: teoria e prática, v. 36, n. 72, 2018.

. Uma república de leitores: história e memória na recepção das Cartas chilenas (1845-1989). São Paulo: Hucitec, 1997.

GARRETT, Almeida. Obras. Porto: Lello \& Irmãos, 1963. v. 1. p. 503-504.

GOMES, Eugênio. Tomás Antônio Gonzaga e o tempo. In: . Visões e revisões. Rio de Janeiro : MEC/INL, 1958. p. 46-53.

GONÇALVES, Adelto. Gonzaga, um poeta do Iluminismo. Rio de Janeiro: Nova Fronteira, 1999.

HANSEN, João Adolfo. “Autor”. In: JOBIM, José Luís. (Org.). Palavras da Crítica. Rio de Janeiro: Imago, 1993.

.As liras de Gonzaga: entre retórica e valor de troca. Via Atlântica, n. 1, 1997, p. 48.

. Prefácio. In: FURTADO, Joaci Pereira. Uma república de leitores: história e memória na recepção das Cartas chilenas (1845-1989). São Paulo: Hucitec, 1997. p. 11-20.

HELENA, Lúcia. Tomás Antônio Gonzaga. Rio de Janeiro: Agir-Edições Biblioteca Nacional, 2005. 
. Gonzaga e a Inconfidência. Revista do Pen Clube do Brasil, Rio de Janeiro, n. 6, dez. 1982, p. 58-66.

HOLANDA, Sérgio Buarque de. Gosto arcádico. In: —. Tentativas de mitologia. São Paulo: Perspectiva, 1979.

JARDIM, Ana Cristina. De "Marília de Dirceu" ao "Romanceiro da Inconfidência": a construção de um mito na sociedade brasileira a partir do século XVIII. Rio de Janeiro: Biblioteca Nacional, 2009.

LAPA, Manuel Rodrigues. As Cartas chilenas: problema histórico e filológico. Rio de Janeiro: MEC/INL, 1958.

LEY, Emanuel Eduardo Gaudie. Gonzaguiana da Biblioteca Nacional. Anais da Biblioteca Nacional, Rio de Janeiro, n. 49., 1927. p. 417-92.

LIMA JUNIOR, A. O amor infeliz de Marília e Dirceu. Rio de Janeiro: A Noite S. A. Editora, 1938.

LUCAS, Fábio. Tomás Antônio Gonzaga, glória entre equívocos. In: . Poesia e prosa no Brasil. Belo Horizonte: Interlivros, 1976. p. 33-48.

LYRA, Pedro. Entre o amor e o poder: Tomás Antônio Gonzaga e o (seu) drama da Inconfidência. Revista Cultural Vozes, Petrópolis, v. 73, n. 2, maio 1979. p. 27-34,

MAXWELL, Kenneth. A farsa. In: . A devassa da devassa. Rio de Janeiro: Paz e Terra, 1977. p. 168-204.

MARTINS, Wilson. “Eu, Marília...”. In: . História da inteligência brasileira. São Paulo: Cultrix, 1978.

MORAES, Rubem Borba de. Bibliografia brasileira do periodo colonial: catálogo comentado das obras dos autores nascidos no Brasil e publicadas antes de 1808. São Paulo: IEB-USP, 1969.

MACHADO, Lourival Gomes. $O$ "Tratado de direito natural de Tomás Antônio Gonzaga. Rio de Janeiro: Ministério da Educação e Saúde, 1953. 144 p.

. Tomás Antônio Gonzaga e o direito natural. São Paulo: Martins/Edusp, 1968.

NEPOMUCENO, Luís André. A musa desnuda e o poeta tímido: o petrarquismo na arcádia brasileira. São Paulo: Annablume, 2002. 
OLIVEIRA, Almir. Gonzaga e a Inconfidência Mineira. Belo Horizonte: Itatiaia; São Paulo: Edusp, 1985. 175 p. (Reconquista do Brasil; nova série especial, 90).

OLIVEIRA, Teresa Cristina Meireles de. O real transfigurado: As liras de Tomás Antônio Gonzaga e a poética do imaginário. Rio de Janeiro: UFRJ, 1993.

POLITO, Ronald. Um coração maior que o mundo: Tomás Antônio Gonzaga e o mundo luso-colonial. São Paulo: Globo, 2006.

A persistência das ideias e das formas: um estudo sobre a obra de Tomás Antônio Gonzaga. Niterói: UFF, 1990.

RAMOS, Péricles Eugênio da Silva. Os mais belos versos da "Escola Mineira”. São Paulo: Melhoramentos, 1964.

RESENDE, Marcelo. Tomás Antônio Gonzaga continua exilado na África. Folha de S.Paulo, 14/01/1998.

ROMERO, Sílvio. Tomás Antônio Gonzaga. In: - História da literatura brasileira. 4. ed., t. 2. Rio de Janeiro: José Olympio, 1949. p. 127-136.

RUEDAS DE LA SERNA, Jorge Antônio. Arcádia: tradição e mudança. São Paulo: Edusp, 1995.

SARAIVA, Antônio J.; LOPES, Oscar. Irradiação e evolução da poesia arcádica. In: História da literatura portuguesa. Porto: Porto Editora, 1975. p. 689-721.

SCHNAIDERMAN, Boris. Pushkin, tradutor de Gonzaga. In: —. Projeções: Rússia/Brasil/Itália. São Paulo: Perspectiva, 1978. p. 37-41.

SILVA, Domingos C. da. Edições brasileiras de Marília de Dirceu. s/1, s/e, 1967, p. 27-32. Gonzaga e outros poetas. Rio de Janeiro: Orfeu, 1970.

SILVA, Joaquim N. de S. Dirceu de Marília: Liras atribuídas a Senhora DMJD de S (natural de Vila Rica). Rio de Janeiro: Fundação Biblioteca Nacional, 1845.

SILVEIRA, Rodrigo C. da. A poética do réu em Marília de Dirceu, de Tomás Antônio Gonzaga. Tese (Doutorado). Letras. UFRJ. 2016.

SOUTHEY, Robert. Conspiração em Minas Geraes no anno de 1788. Revista Trimensal de Historia e Geographia, Rio de Janeiro, n. 8, p. 297-311, jul.-set. 1846.

TEIXEIRA, Ivan. Mecenato pombalino e poesia neoclássica: Basílio da Gama e a poética do encômio. São Paulo: Edusp, 1999. 
VARNHAGEN, Francisco A. Florilégio da poesia brasileira. Tomo II. Rio de Janeiro: Academia Brasileira de Letras, 1946.

VERÍSSIMO. José. Gonzaga. In: ——. Estudos da literatura brasileira. Introdução de Vivaldi Moreira. $2^{\mathrm{a}}$ série. São Paulo: Edusp, 1977. p. 119-124.

\section{Outros estudos}

ABREU, Márcia. Diferentes formas de ler. Apresentação oral. Mesa-redonda "Práticas de Leituras: história e modalidades". XXIV Congresso Brasileiro de Ciências da Comunicação. Campo Grande, Intercom, 2001.

ALI, Manoel Said. Versificação portuguesa. Prefácio de Manuel Bandeira. São Paulo: Edusp, 1999.

ANDERSON, Perry. Linhagens do Estado absolutista. São Paulo: Editora Unesp, 2016.

ARISTÓTELES. Organon. Trad. Edson Bini. São Paulo: Edipro, 2016.

. Poética. Trad. Edson Bini. São Paulo, Edipro, 2011.

. Retórica. Trad. Edson Bini. São Paulo: Edipro, 2016.

AUERBACH, E. Figura. Trad. Duda Machado. Rev. da trad. José Marcos Macedo e Samuel Titan Jr. Pref. Modesto Carone. São Paulo: Ática, 1997.

BANDEIRA. Manuel. "Versificação em língua portuguesa", in Enciclopédia DeltaLarousse, v. 6, Rio de Janeiro: Delta, 1964.

BARDARA, Sérsi. A função dos dêiticos na estruturação do texto. Entremeios: revista de estudos do discurso. v. 3, jul. 2011

BERNARDES, Diogo. Obras completas, v. I - Rima Vária - Flores do Lima. Prefácio e notas do professor Marques Braga. Lisboa: Sá da Costa, 1945.

BLUTEAU, Raphael. Vocabulário português e latino, v. 5. Lisboa: Oficina de Pascoal da Silva, 1716.

BOILEAU-DESPRÉAUX, Nicolas. $A$ arte poética. Intr., trad. e notas de Célia Berrettini. São Paulo: Perspectiva, 1979. 
BRANDÃO, Roberto de Oliveira. As fontes da poesia. In: Poética e poesia no Brasil (Colônia). São Paulo: Editora Unesp/Imprensa Oficial do Estado, 2001. p. 47-63.

BURKE, Peter. A fabricação do rei: a construção da imagem pública de Luís XIV. Rio de Janeiro: Jorge Zahar, 1994. 254 p.

CARVALHO, Amorim de. Das estrofes e dos sistemas estróficos. In: Tratado de versificação portuguesa. Coimbra: Almedina, 1991. p. 91-130.

CARVAlHO, Maria do Socorro F. de. Poesia de agudeza em Portugal. São Paulo: Humanitas-Edusp-Fapesp, 2007.

CHARTIER, Roger. A ordem dos livros: leitores, autores e bibliotecas na Europa entre os séculos XIV e XVIII. Tradução de Mary del Priore. Brasília: Editora da UnB, 1994.

CHAUVIN, Jean Pierre. 'Pictorico', categoria do seiscentos? Revista Teresa, n. 18, p. 133149. São Paulo: USP.

. Marquês de Pombal: retrato sem moldura. Revec, n. 4, 2016.

. Retórica, controvérsia do Oitocentos. Revista Patrimônio \& Memória. Assis: Cedap/Unesp, v. 13, n. 2, p. 14-27.

CURTIUS, Ernest Robert. A poesia como entretenimento. In: . Literatura europeia e Idade Média latina. Trad. Teodoro Cabral e Paulo Rónai. São Paulo: Hucitec/Edusp, 1996. p. 583-584.

Dictionnaire Bibliographique des Auteur du tout les temps et de tous les pays. Bouquins: Robert Laffont, 1980, 4 vols.

Diccionario da lingua portugueza composto pelo padre D. Rafael Bluteau, reformado, e accrescentado por Antonio de Moraes Silva natural do Rio de Janeiro. (Volume 1: A - K) Lisboa: Na Officina de Simão Thaddeo Ferreira, 1789.

ELIAS, Norbert. A sociedade de corte. Trad. de Ana Maria Alves. Lisboa: Editorial Estampa, 1987. 240 p.

FERREIRA, Ana Filipa G. Voz feminina nas éclogas de Diogo Bernardes e Luís de Camões. Centro de Estudos Clássicos. Departamento de Estudos Românicos. Lisboa: Faculdade de Lisboa, 2016.

FREIRE, Francisco José (Cândido Lusitano). Do fim da poesia (Cap. 4). In: Arte 
poética ou regras da verdadeira poesia em geral... Lisboa: Oficina Patriarcal de Francisco Luís Ameno, 1759. p. 26-30.

. Arte poética ou regras da verdadeira poesia em geral. Lisboa: Oficina Francisco Luis Ameno, 1748.

GENETTE, Gérard. Introdução ao arquitexto. Lisboa: Vega, 1987.

. Paratextos editoriais. Trad. Álvaro Faleiros. Cotia (SP): Ateliê Editorial, 2009.

HANSEN, João Adolfo. Alegoria: construção e interpretação da metáfora. São Paulo: Atual, 1986.

HANSEN, João Adolfo. Autor. In: JOBIM, José Luís. Palavras da crítica: tendências e conceitos no estudo da literatura. Rio de Janeiro: Imago, 1992. p. 11-43.

. A sátira e o engenho: Gregório de Matos e a Bahia do século XVII. 2. ed. Cotia (SP): Ateliê; Campinas: Editora Unicamp, 2004.

; MOREIRA, Marcello. Para que todos entendais: poesia atribuída a Gregório de Matos e Guerra - Letrados, manuscritura, retórica, autoria, obra e público na Bahia dos séculos XVII e XVIII. Belo Horizonte: Autêntica, 2013.

IEB, 2012.

. Lugar comum. In: Retórica. Org. de Adma Muhana. São Paulo: Annablume;

. Ilustração católica, pastoral árcade e civilização. Ouro Preto: Oficina da Inconfidência; n. 10, 1999. p. 11-47.

HASEGAWA, Alexandre Pinheiro. Os limites do gênero bucólico em Virgílio. São Paulo: Humanitas, 2011.

HOLANDA, Sérgio Buarque de. O ideal arcádico. In: - Capítulos de literatura colonial. Org. e int. Antônio Candido. São Paulo: Brasiliense, 2000. p. 177-226.

HORÁCIO. Arte poética. Introdução, tradução e comentários de R. M. Rosado Fernandes. Ed. bilíngue. Lisboa: Inquérito, 1984.

LACHAT, Marcelo. Saudades de Lidia e Armido - Poema atribuído a Bernardo Vieira Ravasco. São Paulo: Alameda, 2018.

LOPES, Hélio. Claudio, o lírico de Nise. São Paulo: Livraria Editora Fernando Pessoa, 1975. 
LUCAS, Fábio. A musa iluminada dos poetas mineiros do século XVIII. In: . Luzes e trevas: Minas Gerais no século XVIII. Belo Horizonte: Editora UFMG, 1998. p. 11-22.

MALARD, Letícia. Literatura e dissidência política. Belo Horizonte: Editora UFMG, 2006.

MARQUES, Pedro. Arcádia Melodiosa no Brasil. Remate de Males, Campinas (SP), v. 37, n. 1, jan.-jun. 2017, p. 59-82.

MARTINS, Paulo. Elegia romana: construção e efeito. Prefácio de João Adolfo Hansen. São Paulo: Humanitas, 2009.

MERQUIOR, José Guilherme. O neoclassicismo. In: De Anchieta a Euclides: breve história da literatura brasileira. Rio de Janeiro: José Olympio, 1977. p. 23-48.

MOLLIER, Jean-Yves. Mollier. A história do livro e da edição: um observatório privilegiado do mundo mental dos homens do século XVIII ao século XX. Trad. Clara Furtado Lins. Varia historia, v. 25, n. 42. Belo Horizonte, jul.-dez. 2009.

MORAES, Rubem Borba de. Bibliografia brasileira do período colonial: catálogo comentado das obras dos autores nascidos no Brasil e publicadas antes de 1808. São Paulo: IEB-USP, 1969.

MOSCA, Lineide do Lago Salvador. (Org.) Retóricas de ontem e de hoje. $2^{\mathrm{a}}$ ed. São Paulo: Humanitas, 2001.

NOGUEIRA, Érico. Verdade, contenda e poesia nos idílios de Teócrito. São Paulo: Humanitas, 2012.

NOVAK, M. G.; NERI, M. L. (Orgs.) Antologia de poesia lírica latina. São Paulo: Martins Fontes, 1992.

OLIVA NETO, João Angelo. Dos gêneros da poesia antiga e sua tradução em português. (Tese de livre-docência). Faculdade de Filosofia, Letras e Ciências Humanas, USP, 2013.

O livro de Catulo. (Org. e trad.) Ed. Bilíngue. São Paulo: Edusp, 1996.

OLIVEIRA, Manoel Botelho de. Poesia completa: música do Parnaso. Lira sacra. Introdução, organização e fichamento do texto de Adma Muhana. São Paulo: Martins Fontes, 2005.

. Música do Parnaso. Organização e estudo crítico de Ivan Teixeira. São Paulo: Ateliê Editorial, 2005. 
PÉCORA, Alcir. O amor da convenção. In: . Máquina de gêneros. São Paulo: Edusp, 2001. p. 189-202.

PLANTIN, Christian. Argumentação: história, teorias, perspectivas. São Paulo: Parábola, 2008.

PLANTIN, Christian; ALEXANDRE, Didier et alli. Lieux communs: topoï, stéréotypes, clichés. Paris: Kimé, 1993.

PINHEIRO, Fernandes. Curso de literatura nacional. $3^{\mathrm{a}}$. ed. Rio de Janeiro: Cátedra/INL, 1978. p. 304-305.

REBOUL, Olivier. Introdução à retórica. Trad. Ivone Castilho Benedetti. São Paulo: Martins Fontes, 1998.

RODOLPHO, Melina. Écfrase e evidência nas letras latinas: doutrina e práxis. São Paulo: Humanitas, 2012.

RODRIGUES JÚNIOR, F. O conceito de poesia bucólica no século III a. C. Revista Helenismo. São Paulo: Humanitas/Fapesp, 2017. p. 131-176.

SILVA, Joaquim N. de S. Brasileiras Célebres. Reedição. Brasília: Senado Federal, 2004.

SOUZA, Caio C. E. de. Alvarenga Peixoto e $(m)$ seu tempo. Dissertação de mestrado. Orientador João Adolfo Hansen. São Paulo: Faculdade de Filosofia, Letras e Ciências Humanas-USP, 2017.

TEIXEIRA, Bento. Prosopopeia. 9. ed. São Paulo: Melhoramentos, 1977.

TEIXEIRA, Ivan. Mecenato pombalino e poesia neoclássica. São Paulo: Edusp/Fapesp, 1999.

THIONVILLE, Eugène. Lugares comuns: a teoria dos lugares comuns nos Tópicos de Aristóteles e as principais modificações que sofreu até os nossos dias. São Paulo: Poiesis, 2007.

VALLE, Ricardo M. A construção da posteridade ou a tradição para o novo mundo ou a gênese como ruína: um estudo sobre as Obras, de 1768, de Cláudio Manuel da Costa. Dissertação de mestrado. Orientador: Prof. Dr. João Adolfo Hansen. São Paulo, Faculdade de Filosofia, Letras e Ciências Humanas, Universidade de São Paulo, 2004. 
VERNEY, Luís Antônio. Verdadeiro método de estudar. 5 vols. Lisboa: Sá da Costa, 1949.

VERNEY, Luís António. Carta sétima. In: . Verdadeiro método de estudar. Valença: Oficina de Antônio Balle, 1746. p. 215-275.

VINSAUF, Geoffroi de. Poetria Nova. Trad., int. e notas de Manuel dos Santos Rodrigues. Lisboa: Instituto Nacional de Investigação Científica. Centro de Estudos Clássicos da Universidade de Lisboa, 1990. 


\section{$M A R I L I A$ \\ $\mathrm{D} \mathbf{E}$ \\ D I R C E O. \\ POR T. A. G.}

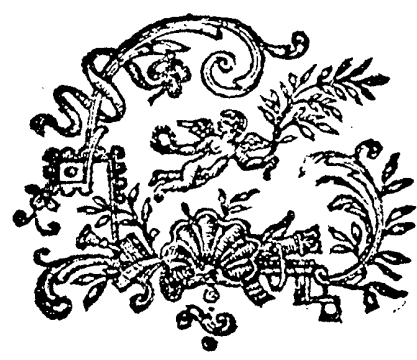

\section{I S B O A: NA TYPOGRAFIA NUNESIANA ANNO M. DCC. XCII. \\ Com Licença da Real Meza da Commu xu Geral Sobre o Exame, e Censura dos L' iros.}

Figura 1 - Imagem da capa da edição princeps de Marília de Dirceu - Edição fac-similada (1792). 


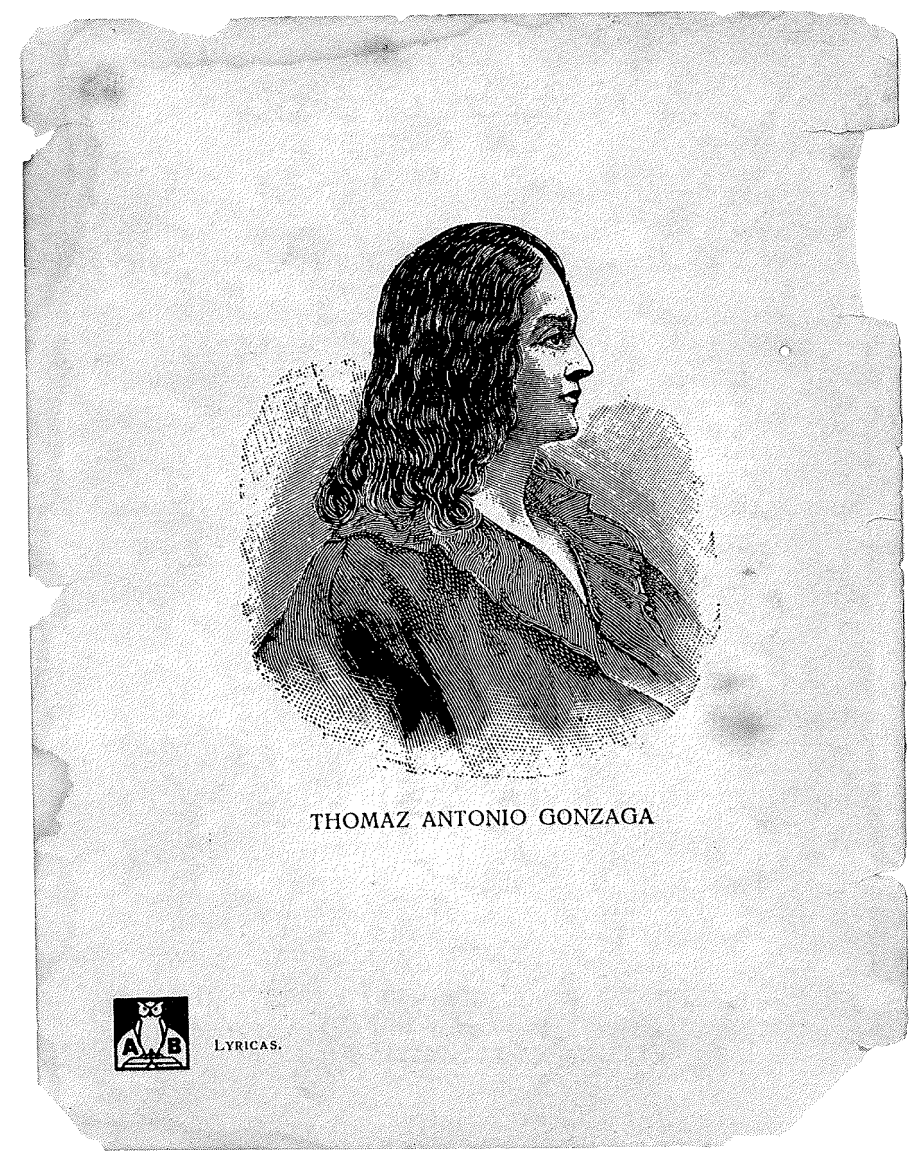

Figura 2 - Imagem do poeta Tomás Antônio Gonzaga a partir do retrato a óleo de Maximiano Mafra (Tomás Gonzaga no Cárcere), exposto no salão de 1844, no Rio de Janeiro. 

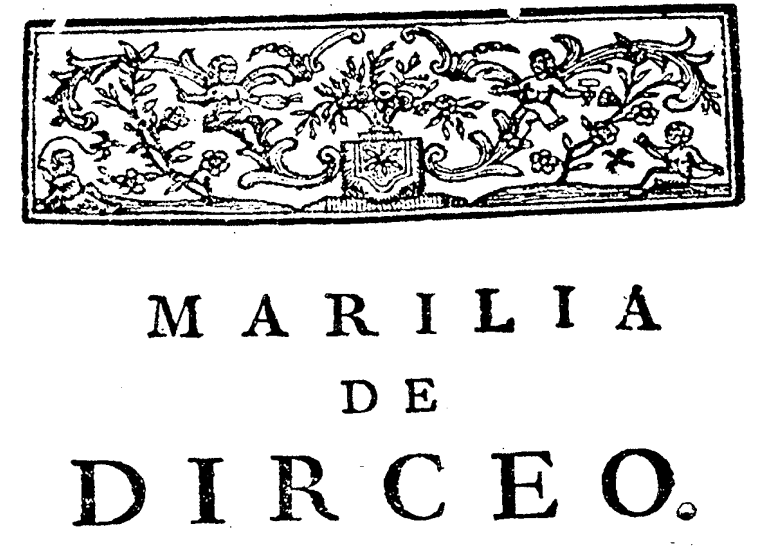

L Y R A I.

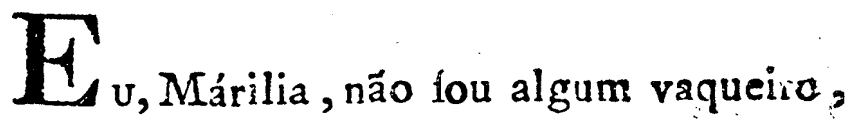

Que viva de guardar -'he: a gado

De tolco trato, de expreflóes groffeiro,

Dos frios gelos, e dos fóes queimado.

Tenho proprio cafal, e nelle a fifto;

Dá-me vinho, legume, fruta, azeite,

Das brancas ovelhinhas tiro o leite,

$E$ mais as finas lans, de que me vilto.

Graças, Marilia bella,

Graças à minha Eftrella !

Ea

Figura 3 - Imagem da página inicial da edição princeps de Marília de Dirceu. - Edição fac-similada (1792). 